\title{
unesp
}

UNIVERSIDADE ESTADUAL PAULISTA

"JÚLIO DE MESQUITA FILHO"

INSTITUTO DE BIOCIÊNCIAS - RIO CLARO

PROGRAMA DE PÓS-GRADUAÇÃO EM CIÊNCIAS BIOLÓGICAS (ZOOLOGIA)

Efeito da cafeína no comportamento e na longevidade de operárias de abelhas africanizadas Apis mellifera L. (Hymenoptera: Apidae)

Valeska Marques Arruda

Tese apresentada ao Instituto de Biociências da Universidade Estadual Paulista "Júlio de Mesquita Filho", Campus de Rio Claro, para a obtenção do título de Doutor em Ciências Biológicas (Área de Concentração:

Zoologia)

\section{Rio Claro}

Estado de São Paulo - Brasil

Fevereiro de 2010 
Efeito da cafeína no comportamento e na longevidade de operárias de abelhas africanizadas Apis mellifera L. (Hymenoptera: Apidae)

Valeska Marques Arruda

Orientador: Prof. Dr. José Chaud Netto

Tese apresentada ao Instituto de Biociências da Universidade Estadual Paulista "Júlio de Mesquita Filho", Campus de Rio Claro, para a obtenção do título de Doutor em Ciências Biológicas (Área de Concentração: Zoologia) 
595.79 Arruda, Valeska Marques

A779e Efeito da cafeína no comportamento e na longevidade de operárias de abelhas africanizadas Apis mellifera L. (Hymenoptera: Apidae) / Valeska Marques Arruda - Rio Claro: [s.n.], 2010

83f. : il., figs., gráfs., tabs., fots.

Tese (doutorado) - Universidade Estadual Paulista, Instituto de Biociências de Rio Claro)

Orientador: José Chaud-Netto

1. Hymenoptera. 2. Comportamento. 3. Divisão de trabalho. 4. Longevidade. 5. Recurso alimentar. 6. Metilxantina. I. Título

Ficha catalográfica elaborada pela STATI - Biblioteca da UNESP

Campus de Rio Claro/SP 
$\underline{\text { ADeus, }}$

Cuja palavra é mais doce do que o destilar dos favos (Salmos 19:10) e sem Ele sou pequena, não teria chegado até aqui. Ele me guiou, orientou e fortaleceu em todos os momentos, e me forneceu capacidade para vencer todas as dificuldades. 
Ao meu esposo e amigo Odacir,

Que esteve presente em todos os momentos e proporcionou amor nos momentos mais difíceis, através de seus gestos e palavras. Seu estímulo e carinho foram muito importantes para esta conquista. Ao meu amado filho Mateus,

Que mesmo sem saber participou deste momento com muita paciência. $\mathscr{D E D I C O}$ 
Plante seu jardim e decore sua alma, ao invés de esperar que alguém the traga flores.

E você aprende que realmente pode suportar...

Que realmente é forte.

Que pode ir muito mais longe

depois de pensar que não se pode mais.

$E$ que realmente a vida tem valor e

que você tem valor diante da vida!

Nossas dádivas são traidoras

e nos fazem perder o bem que poderíamos conquistar

se não fosse o medo de tentar.

William Shakespeare 


\section{AGRADECIMENTOS}

Ao meu orientador Prof. Dr. José Chaud Netto pela confiança, dedicação e acima de tudo pelos conselhos, carinho, amizade, exemplo de vida e caráter. Agradeço também por me ensinar a importância dos pequenos detalhes que é essencial para um pesquisador que trabalha com comportamento.

Ao Prof. Dr. Valter Vieira Alves Júnior pela amizade, confiança e oportunidade oferecida em me apresentar ao Prof. Dr. José Chaud-Netto, e assim permitir a realização deste sonho de concluir o doutorado.

Ao Conselho do Programa de Pós-graduação em Ciências Biológicas (Área de Concentração: Zoologia) da Universidade Estadual Paulista "Júlio de Mesquita Filho", Campus de Rio Claro - SP.

Às secretárias da Seção de Pós-Graduação do I.B, em especial à Rute M. R. Camargo.

À Coordenação de Aperfeiçoamento de Pessoal de Nível Superior (CAPES) e ao Conselho Nacional de Desenvolvimento Científico e Tecnológico (CNPq) pela concessão da bolsa de doutorado.

Aos Professores do Curso de Pós - Graduação, que estiveram presentes a todo instante e participaram ativamente deste processo de desenvolvimento e capacitação. Agradeço, particularmente, à $\operatorname{Prof}^{\mathrm{a}} \operatorname{Dr}^{\mathrm{a}}$ Sulene Noriko Shima pelas ótimas sugestões que apresentou ao examinar os relatórios de pesquisa que elaborei ao longo do Doutorado.

Agradeço especialmente ao Antonio Sérgio Pascon, técnico apícola do Instituto de Biociências, pelo valioso auxílio na coleta e manutenção dos ninhos, bem como pela companhia durante o desenvolvimento da parte prática do presente trabalho.

À memória de meu pai, Noé Stein Arruda, que sempre participou das minhas conquistas neste trajeto, me apoiando e torcendo por mim. Á minha mãe, Ivanilde Gonzaga Marques, e ao meu irmão, Noé Stein Arruda Junior, que sempre estiveram prontos a me auxiliar. 
Ao amigo, e atual Doutor em Zoologia, Erico Nomura pela companhia e auxílio em todos os momentos, até mesmo antes de iniciar o curso e, principalmente, pela amizade dedicada. Meu MUITO OBRIGADA!!!

Ao doutorando Andrigo M. Pereira, que esteve presente durante a realização deste trabalho, sempre pronto a oferecer ajuda e esclarecimentos técnico-científicos.

Aos amigos Gisele L. Varotti, Mariana M. Morelli, Bruno Berger, João R. Nascimento e Célia R. R. C. Dietrich, pela ótima companhia, momentos maravilhosos e de muitas risadas. 


\section{LISTA DE ILUSTRAÇÕES}

Página

Figura 1. Apiário localizado no Campus da Universidade Estadual Paulista "Júlio de Mesquita Filho", em Rio Claro - SP, onde se localiza a colônia matriz de onde foram retiradas as operárias recém-emergidas para marcação e posterior introdução nas colméias de observação instaladas no laboratório do biotério

Figura 2. Operárias de Apis mellifera marcadas com disco plástico numerado, segundo a técnica descrita por Pereira e Chaud-Netto (2008)

Figura 3. Vista geral de uma das colméias de observação utilizadas para estudar os comportamentos das operárias de Apis mellifera L.

Figura 4. Esquema da colméia de observação (a) e da caixa de madeira (b) utilizadas para registrar a atividade coleta de recursos alimentares por operárias de Apis mellifera L.

Figura 5. Vista geral da colméia de observação (a) e da caixa de madeira (b) utilizadas para registrar o comportamento de coleta de recursos alimentares por operárias de Apis mellifera $\mathrm{L}$.

Figura 6. Vista da caixa de madeira acoplada à colméia de observação instalada no biotério: (a) vista geral; (b) vista superior

Figura 7. Frequiência relativa (\%) de abelhas africanizadas dos grupos controle e experimental que realizaram atividade de limpeza

Figura 8. Freqüência relativa (\%) de abelhas africanizadas dos grupos controle e experimental que fizeram autolimpeza

Figura 9. Frequiência relativa (\%) de abelhas africanizadas dos grupos controle e experimental que realizaram limpeza de células

Figura 10. Frequiência relativa (\%) de abelhas africanizadas dos grupos controle e experimental que solicitaram limpeza corporal

Figura 11. Freqüência relativa $(\%)$ de abelhas africanizadas dos grupos controle e experimental que realizaram limpeza de outras operárias

Figura 12. Freqüência relativa (\%) de abelhas africanizadas dos grupos controle e experimental que foram limpas por outras operárias

Figura 13. Frequiência relativa $(\%)$ de abelhas africanizadas dos grupos controle e experimental que realizaram atividade de inspeção

Figura 14. Freqüência relativa (\%) de abelhas africanizadas dos grupos controle e experimental que realizaram atividade de termorregulação

Figura 15. Freqüência relativa (\%) de abelhas africanizadas dos grupos controle e experimental que realizaram atividade de construção de favo

Figura 16. Freqüência relativa (\%) de abelhas africanizadas dos grupos controle e experimental que realizaram atividade de recepção de alimento

Figura 17. Frequiência relativa (\%) de abelhas africanizadas dos grupos controle e experimental que realizaram atividade de defesa da colônia

Figura 18. Frequiência relativa (\%) de abelhas africanizadas dos grupos controle e experimental que realizaram atividade de alimentação larval

Figura 19. Frequiência relativa (\%) de abelhas africanizadas dos grupos controle e experimental que coletaram recursos alimentares

Figura 20. Frequiência relativa (\%) de operárias de abelhas africanizadas dos grupos controle e experimental que realizaram coleta de pólen 


\section{LISTA DE ILUSTRAÇÕES}

Página

Figura 21. Frequiência relativa (\%) de operárias de abelhas africanizadas dos grupos controle e experimental que realizaram coleta de néctar 59

Figura 22. Frequiência relativa (\%) de operárias de abelhas africanizadas dos grupos controle e experimental que saíram da colméia

Figura 23. Freqüência relativa $(\%)$ de operárias de abelhas africanizadas dos grupos controle e experimental que retornaram à colméia

Figura 24. Curvas de sobrevivência das operárias de Apis mellifera pertencentes aos grupos controle e experimental

Figura 25. Resultado da análise de correlação de Spearman ( $r s=0,04 ; p>0,05$ ) entre os dados referentes à longevidade das operárias do grupo controle e a temperatura externa $\left({ }^{\circ} \mathrm{C}\right)$

Figura 26. Resultado da análise de correlação de Spearman ( $r s=-0,08 ; p>0,05)$ entre os dados referentes à longevidade das operárias do grupo experimental e a temperatura externa $\left({ }^{\circ} \mathrm{C}\right)$ 


\section{LISTA DE TABELAS}

Página

Tabela 1. Valores referentes à idade (em dias), freqüência relativa e resultados obtidos na análise estatística (Teste Mann-Whitney - U) dos dados de operárias de Apis mellifera dos grupos controle e experimental, que realizaram as diversas atividades comportamentais observadas.

Tabela 2. Valores obtidos nas Análises de Correlação de Spearman (rs) entre os dados 40 referentes ao número de abelhas que entraram e saíram das colméias, os recursos alimentares que elas coletaram e as variáveis ambientais registradas (temperatura, umidade relativa, pressão atmosférica, pluviosidade e velocidade do vento) 


$\begin{array}{lc}\text { RESUMO } & \text { Página } \\ \text { ABSTRACT } & 10 \\ \text { 1. INTRODUÇÃO } & 12 \\ \text { 2. REVISÃO DA LITERATURA } & 17 \\ \text { 3. OBJETIVOS } & 32 \\ \text { 4. MATERIAL E MÉTODOS } & 33 \\ \text { 4.1. Análise dos Resultados obtidos } & 37 \\ \text { 5ESULTADOS E DISCUSSÃO } & 38 \\ \text { 1. Descrição do comportamento de abstinência } & 38 \\ \text { 2. Divisão de trabalho entre operárias de diferentes idades } & 39 \\ \text { 5.2.1. Atividade de limpeza } & 39 \\ \text { 5.2.2. Atividade de inspeção } & 47 \\ \text { 5.2.3. Atividade de termorregulação } & 48 \\ \text { 5.2.4. Atividade de construção } & 50 \\ \text { 5.2.5. Atividade de recepção de alimento } & 52 \\ \text { 5.2.6. Atividade de defesa } & 54 \\ \text { 5.2.7. Atividade de alimentação larval } & 55 \\ \text { 5.2.8. Atividade de coleta de recursos alimentares } & 57 \\ \text { 3. Longevidade } & 63 \\ \text { CONSIDERAÇÕES FINAIS } & 68 \\ \text { 7. REFERÊNCIAS BIBLIOGRÁFICAS } & 71\end{array}$




\section{Efeito da cafeína no comportamento e na longevidade de operárias de abelhas africanizadas Apis mellifera L. (Hymenoptera: Apidae)}

RESUMO: Nesta pesquisa estudou-se o efeito da cafeína nas atividades referentes à divisão de trabalho entre operárias de abelhas africanizadas (Apis mellifera L.), bem como na longevidade dessas abelhas. As atividades estudadas foram: limpeza, inspeção, termorregulação, construção, coleta, recepção de alimento, defesa da colônia e alimentação larval. A atividade de coleta de alimento e a longevidade das operárias em relação às variáveis ambientais: índice pluviométrico $(\mathrm{mm})$, pressão atmosférica $(\mathrm{mb})$, temperatura $\left({ }^{\circ} \mathrm{C}\right)$, umidade relativa do ar $(\%)$ e velocidade do vento $(\mathrm{Km} / \mathrm{h})$ também foram analisadas. Foram utilizadas duas colônias alojadas em colméias de observação, sendo que uma delas (grupo controle) foi alimentada com $50 \mathrm{~g}$ de cândi ( $85 \%$ de glaçúcar $+15 \%$ de mel), enquanto a outra (grupo experimental) recebeu 49,67g de cândi misturado a 0,33g de cafeína. Essa alimentação foi administrada semanalmente às abelhas das duas populações durante três meses consecutivos. Em cada colméia foram introduzidas 606 operárias recém-emergidas, marcadas com discos plásticos numerados colados ao tórax, provenientes de uma colônia matriz de abelhas africanizadas contendo uma rainha fecundada em vôo livre. Os resultados da pesquisa revelaram que a frequência de operárias do grupo experimental que fizeram autolimpeza (65\%), recepção de alimento (5\%), alimentação larval e coleta de recursos alimentares (3\%) foi maior em relação às abelhas do grupo controle. No que se refere à construção de favos, as operárias alimentadas com dieta contendo cafeína confeccionaram um número de células (401) quase duas vezes maior em relação às operárias que receberam dieta normal. O fluxo de coleta de pólen e néctar foi maior no grupo experimental (89\%) e as abelhas deste grupo iniciaram a atividade de coleta em uma idade precoce, mas o período de maior atividade de coleta de recursos alimentares foi semelhante nos dois grupos (entre 34 e 40 dias), para abelhas com idade mais avançada. As operárias do grupo controle apresentaram maior longevidade média $(27,60 \pm 0,72$ dias $)$ em relação às operárias do grupo experimental $(16,34$ $\pm 0,72$ dias). As abelhas deste grupo iniciaram as tarefas: ser limpa por operária, construção, recepção e coleta de recursos (pólen) mais cedo em relação às operárias do grupo controle. As análises entre as variáveis ambientais e os dados de longevidade, fluxo de coleta de recursos, entrada e saída de abelhas indicaram correlação significativa somente entre as variáveis pressão atmosférica $(\mathrm{mb})$ e fluxo de entrada de abelhas na colônia ( $\mathrm{rs}=-0,33$ ), apenas para as abelhas do grupo controle. Aproximadamente $13 \%$ das abelhas do grupo experimental desenvolveram sintomas de abstinência, tais como compulsão, agitação, alterações de 
sensibilidade no tegumento, falta de coordenação motora e tremores. As comparações dos resultados referentes às atividades de autolimpeza, limpeza de células, inspeção, termorregulação, construção, defesa da colônia e alimentação larval, bem como dos dados de longevidade obtidos para as operárias dos grupos controle e experimental, revelaram diferenças significativas, indicando que a cafeína interferiu na divisão de trabalho e na sobrevivência das abelhas.

Palavras-chave: Divisão de trabalho. Dieta alimentar. Abstinência. Metilxantina. 


\section{Effect of caffeine on behavior and longevity of Africanized honeybee workers Apis mellifera L. (Hymenoptera: Apidae)}

ABSTRACT: In this study the effects of caffeine on activities related to the division of labor among Africanized honeybee workers (Apis mellifera L.), and also on the longevity of these bees were investigated. The activities studied were: cleaning, inspection, temperature regulation, construction, collect of food resources, receiving food, defense of the colony and larval feeding. The gathering of food resources and the longevity of the worker bees in relation to the environmental variables: rainfall $(\mathrm{mm})$, atmospheric pressure $(\mathrm{mb})$, temperature $\left({ }^{\circ} \mathrm{C}\right)$, relative air humidity $(\%)$ and wind speed $(\mathrm{km} / \mathrm{h})$ were also analyzed. Two colonies of honeybees maintained in observation hives were used in this research. One of them (control group) was fed with $50 \mathrm{~g}$ of candy ( $85 \%$ of glaçucar plus $15 \%$ of honey), and the other (experimental group) received $49.67 \mathrm{~g}$ of candy mixed with $0.33 \mathrm{~g}$ of caffeine. This feeding was given weekly to the bees of these populations for three consecutive months. In each hive 606 newly-emerged worker bees, marked on the thorax with numbered plastic discs, were introduced. These bees came from a mother colony of Africanized honeybees which contained a fertilized queen in free flight. The results of this research revealed that the frequency of worker bees from the experimental group which made self-cleaning (65\%), receiving food (5\%), larval feeding (3\%) and collect of food resources (3\%) was higher in relation to the rates obtained for the control group. Concerning the construction of combs, the workers fed with diet containing caffeine made a number of cells (401) almost twice as large as that of the workers which received normal diet. The flow of the pollen and nectar collected was higher in the experimental group (89\%) and the bees from this group started this task in the early age, but the period of greater activity was similar in both groups (between 34 and 40 days), for the oldest bees. The bees from the control group presented an average life span $(27,60 \pm 0,72$ days $)$ greater than the workers of the experimental group $(16,34 \pm 0,72$ days $)$. The workers of this last group started the tasks: to be cleaned by worker bee, construction, receiving and collecting pollen in an early age in relation to the bees from the control group. The analyses among the environmental variables and the data of longevity, flow of resources collected, input and output of bees, indicated a significant correlation result between the atmospheric pressure $(\mathrm{mb})$ and the input ( $\mathrm{rs}=-0,33$ ) flow of the bees from the control group. About $13 \%$ of the bees from the experimental group presented symptoms of abstinence as compulsion, agitation, changes in sensitivity in the tegument, lack of motor coordination and tremors. The comparison of the results regarding the activities of self-cleaning, cleaning of 
cells, inspection, thermoregulation, construction, defense of the colony and larval feeding, as well the data of longevity recorded for both groups of honeybee workers, revealed significant differences and indicated that caffeine interfered on division of labor and also on the longevity of the bees.

Keywords: Division of labor. Diet Food. Abstinence. Methylxanthine. 


\section{INTRODUÇÃO}

Entre os insetos considerados eussociais os mais derivados são as abelhas, as formigas, os cupins e as vespas. As abelhas Apis mellifera vivem em colônias constituídas por uma rainha, milhares de operárias e algumas dezenas, ou mesmo centenas, de zangões. A rainha é a fêmea reprodutora dominante da colônia, sendo responsável pela deposição dos ovos que darão origem aos demais membros da população. Aos zangões cabe a importante função de fecundar a rainha no período de acasalamento, ao passo que as operárias realizam todas as atividades referentes à manutenção e defesa da colônia (WILSON, 1971; MICHENER, 1974; FREE, 1980). Estes indivíduos têm comportamento extremamente estereotipado, determinado por um forte componente genético, que lhes garante uma ótima adaptação ao ambiente (GONÇALVES e STORT, 1978; MORITZ e SOUTHWICK, 1992).

Vários pesquisadores verificaram que as operárias de Apis mellifera realizam tarefas que mudam à medida que elas envelhecem. No Brasil, em condições de clima subtropical, as abelhas operárias vivem de quatro a seis semanas no verão (TERADA et al., 1975). Segundo Free (1980), nas primeiras duas ou três semanas de vida elas realizam as tarefas internas do ninho e, nas restantes, elas se dedicam à coleta de néctar, pólen, água e própolis. No entanto, existe grande variação na idade em que as abelhas realizam as diversas tarefas no ninho e na qual iniciam as atividades de coleta. Em geral, as abelhas que começam a coletar recursos alimentares precocemente podem abreviar ou até mesmo omitir algumas atividades no ninho, isto é, quanto mais cedo elas fizerem os primeiros vôos de orientação, mais cedo realizarão as primeiras viagens de coleta. Além disso, dependendo das necessidades da colônia, abelhas 
que já executaram determinadas tarefas no interior do ninho, em faixas etárias anteriores, podem voltar a realizá-las, mesmo se já estiverem trabalhando em atividades externas (RIBBANDS, 1953; WILSON, 1971; FREE,1980).

A cafeína é uma substância estimulante, que ocupa uma posição de destaque entre as drogas mais consumidas em todo o mundo. É largamente utilizada pelos seres humanos, que geralmente têm o hábito de consumir café, chá, refrigerantes e/ou chocolate, principalmente na população idosa e de meia idade (D'AMICIS e VIANI, 1993). Segundo esses mesmos autores, na população jovem o consumo moderado de cafeína aumentou em 14\% até o início da década de 90. A suposição de que a cafeína e/ou as metilxantinas em geral possam aumentar o desempenho dos atletas durante a prática de diferentes esportes provocou um grande interesse científico e foi à base para o desenvolvimento de inúmeras pesquisas (NEHLING e DEBRY, 1994).

Poucos estudos têm sido realizados sobre os efeitos da cafeína em insetos. Ishay e Paniry (1979) estudaram os efeitos da cafeína e de outras xantinas em determinados comportamentos de vespas. Segundo os mencionados autores, o efeito da cafeína está associado à quantidade de tecido adiposo presente em cada indivíduo considerado. Operárias jovens, machos e rainhas que consumiram cafeína somente foram excitados depois que a gordura se saturou com o material ingerido. Como nas operárias adultas quase não há gordura, elas responderam mais cedo ao tratamento com cafeína.

Em vários organismos, incluindo os seres humanos, a cafeína afeta quase todos os sistemas, sendo que seus efeitos mais óbvios ocorrem no sistema nervoso central (SNC). Quando consumida em baixas dosagens $(2 \mathrm{mg} / \mathrm{kg})$, a cafeína provoca aumento do estado de vigília, diminuição da sonolência, alívio da fadiga, aumento na atividade respiratória, na freqüência cardíaca, no metabolismo, na liberação de catecolaminas e diurese. Em altas dosagens $(15 \mathrm{mg} / \mathrm{kg})$ causa nervosismo, insônia, tremores e desidratação (CONLEE, 1991). Porém, a ação da cafeína depende do tipo, da intensidade e da duração do exercício ao qual o organismo é submetido, do seu estado nutricional e de treinamento, da dose de cafeína utilizada, habituação a metilxantinas, condições ambientais, além de possíveis variações individuais durante o exercício (NEHLING e DEBRY, 1994; GRAHAN et al., 1994).

A inclusão da cafeína na alimentação das abelhas Apis mellifera pode ser um recurso alternativo para os apicultores que desejarem aumentar as populações de suas colônias e, conseqüentemente, a produção de mel durante uma estação em particular. Dessa forma, é importante desenvolver estudos sobre os efeitos da cafeína na longevidade e no 
comportamento de operárias de Apis mellifera L. para verificar se essa alternativa é viável e se pode ou não ser colocada em prática. 


\section{REVISÃO DA LITERATURA}

Segundo Pardo et al. (1988) a Apis mellifera Linnaeus originou-se na África, Europa e Ásia Menor, tendo sido transportada para diferentes lugares do mundo graças ao homem. As subespécies de origem européia foram introduzidas na América do Sul por volta do século XVII, passando a ocupar as regiões temperadas, subtropicais e, em menor escala, as regiões tropicais (SEELEY, 1985; VILLA, 1987). Segundo Nogueira-Neto (1972), as primeiras abelhas européias foram introduzidas no Brasil em 1839, por imigrantes portugueses. A partir de então, as colônias que sobreviveram à longa viagem entre a cidade do Porto e o Rio de Janeiro começaram a produzir enxames naturais, em regiões cujas condições ambientais eram semelhantes às de sua origem.

Até a década de 50, o Brasil ocupava o modesto $27^{\circ}$ lugar na produção mundial de mel, apesar de possuir ótimas condições em termos de pasto apícola. Pensando unicamente no desenvolvimento da apicultura nacional, o Prof. Dr. Warwick Estevam Kerr elaborou um projeto científico para obter uma raça de abelhas mais apropriada às condições brasileiras, em relação às raças que haviam sido importadas da Europa. Para concretizar essa idéia, rainhas de Apis mellifera scutellata, cuja descendência, presumivelmente, seria mais adaptada às condições tropicais brasileiras, foram trazidas da Tanzânia e da Cidade do Cabo (África do Sul) em 1956, sendo introduzidas em colônias experimentais mantidas no horto de Camacuã, situado a aproximadamente $14 \mathrm{~km}$ de Rio Claro (KERR, 1967). 
Em março de 1957, as 26 colônias africanas sobreviventes produziram enxames naturais que escaparam de suas colméias originais e suas rainhas (virgens) se acasalaram com zangões de abelhas européias existentes na região. As colônias que atualmente são encontradas na natureza são chamadas de abelhas africanizadas, um poli-híbrido resultante dos primeiros cruzamentos entre rainhas de Apis mellifera scutellata e zangões das subespécies Apis mellifera mellifera (abelha alemã), Apis mellifera ligustica (abelha italiana) e Apis mellifera caucasica (abelha caucasiana) (STORT e GONÇALVES, 1994). Entretanto, segundo Ruttner (1986), quando as rainhas de Apis mellifera scutellata foram introduzidas no Brasil, a subespécie encontrada com maior freqüência em nosso país era a Apis mellifera iberica, originária da Europa Ocidental. O mesmo autor destacou, ainda, que a referida subespécie teria tido maior contribuição na formação das abelhas africanizadas atuais. Estas abelhas híbridas rapidamente se dispersaram pela América do Sul, deslocando assim as subespécies européias pré-existentes no ambiente (GONÇALVES, 1982).

Em uma colônia normal de Apis mellifera existe uma rainha (fêmea fértil), milhares de operárias (fêmeas estéreis) e dezenas de zangões (machos). As tarefas de manutenção da colônia são realizadas pelas operárias, a rainha é responsável pela deposição dos ovos e os zangões restringem-se ao acasalamento (MICHENER, 1974; FREE, 1980).

Segundo Ribbands (1953), o dimorfismo das castas em Apis mellifera é determinado pela diferença na qualidade e valor nutritivo do alimento que as fêmeas recebem, a partir do segundo e terceiro dias de vida larval. As larvas que dão origem a rainhas recebem uma dieta rica em geléia real. Essa alimentação mais nutritiva provocará um maior desenvolvimento da glândula endócrina chamada corpora allata e, conseqüentemente, haverá produção de uma grande quantidade de Hormônio Juvenil (HJ) (DIXON e MOSER, 1972). Este hormônio previne a morte celular programada, fazendo com que a rainha tenha um desenvolvimento ovariano completo (SCHMIDT et al., 1998). Por outro lado, as larvas de operárias recebem uma dieta menos nutritiva (geléia real diluída, pólen e mel), que induz a morte celular programada (REGINATO e CRUZ-LANDIM, 1998, 2001, 2002) e faz com que a abelha tenha um desenvolvimento ovariano deficiente.

As operárias de Apis mellifera apresentam uma divisão de trabalho que compreende algumas atividades que variam com a idade, com as necessidades da colônia e as condições ambientais. As diversas funções realizadas pelas abelhas envolvem não apenas o comportamento, mas também a fisiologia dos indivíduos da colônia, pois estão diretamente ligadas ao desenvolvimento glandular e dependem de uma complexa interação entre genótipo e meio ambiente (MICHENER, 1974; CALDERONE, 1998). As atividades comportamentais 
das abelhas envolvem a limpeza da colméia, alimentação de crias, construção de favos, recepção de néctar, defesa da colônia, comunicação e coleta de alimento (RIBBANDS, 1952; LINDAUER, 1953; SAKAGAMI, 1953; FREE, 1980). Vários autores realizaram estudos sobre estas atividades e, muitas vezes, foram obtidos resultados divergentes (RIBBANDS, 1952; LINDAUER, 1953; MALASPINA, 1982). Rosch (1927, 1930 in MORITZ e SOUTHWICK, 1992) e Lindauer (1952) salientaram que os principais fatores que determinam o polietismo são de natureza ambiental, incluindo a idade das operárias.

Contudo, a divisão de trabalho não é inalterável e as operárias apresentam considerável variação no que se refere ao desenvolvimento de algumas tarefas (Seeley, 1982). Além disso, grande parte das variações observadas no comportamento das operárias é decorrente de sua variabilidade genética (ROBINSON e PAGE, 1989). Alguns autores verificaram que as operárias de certas patrilíneas (conjunto de abelhas descendentes de um mesmo zangão), que podem ser identificadas por meio de isoenzimas (por exemplo, a malatodesidrogenase), são geneticamente programadas para realizar determinadas funções (CALDERONE e PAGE, 1988; ROTHENBUHLER e PAGE, 1989; PAGE et al., 1989 a,b; PAGE e ROBINSON, 1991). Frumhoff e Baker (1988) e Kolmes et al. (1989) chegaram à mesma conclusão, usando linhagens de abelhas contendo genes marcadores que determinam fenótipos de fácil visualização. Por exemplo, em uma dada colônia o número de operárias de uma patrilínea, que trabalharão na defesa da colméia, pode ser significativamente maior em relação aos demais conjuntos de abelhas. Em outra patrilínea as operárias podem ser especializadas na limpeza da colméia. Esses estudos não invalidam o conceito geral do polietismo dependente da idade. Eles simplesmente indicam que o genótipo de cada abelha também é importante para determinar com que frequência ela realizará uma determinada função na colônia.

No Brasil, foram realizadas muitas pesquisas com a abelha Apis mellifera para conhecer seu comportamento e suas estratégias de coleta. Comparando a produtividade de abelhas européias e africanizadas, Nascimento-Júnior (1981) observou que quando as condições climáticas são adequadas as primeiras aumentam a produção de mel. Segundo o referido autor, em uma colônia a produção de mel serve de estimulo para postura dos ovos e estes, por sua vez, dão origem a larvas que estimulam a coleta e o armazenamento de pólen. Neste período, quando ocorre aumento da temperatura externa, as abelhas realizam um maior número de coletas e a quantidade de mel produzido pela colônia é muito grande, o que elimina a necessidade de um grande número de abelhas para a manutenção da população, considerando as condições favoráveis da colméia. Nesta fase, a rainha pode iniciar a produção 
de zangões até a colônia atingir o máximo de produção, para propiciar a enxameação (divisão natural da colônia). No caso das abelhas africanizadas, embora também haja aumento populacional e na produção de mel quando as condições ambientais são adequadas, a temperatura não é o fator mais importante nas variações da produtividade da colônia, mas sim o regime periódico de chuvas.

Chaud-Netto (1992) observou que o regime de chuvas tem influência significativa na estabilidade das colônias de abelhas africanizadas. No inverno o número de operárias de cada colônia não diminui em demasia, como ocorre nas populações de abelhas de origem européia, porque as rainhas de abelhas africanizadas geralmente mantêm a taxa de postura. Contudo, em períodos chuvosos prolongados, as operárias param de coletar alimento, consomem todo o mel estocado na colméia e a rainha pode interromper a deposição de ovos. Quando isso acontece, as abelhas abandonam a colméia e procuram um local mais apropriado para construção de um novo ninho, ao invés de se aglomerarem e esperarem a passagem do período crítico, como ocorre com as abelhas de origem européia.

Em pesquisas realizadas no Brasil, Nuñez (1979) observou que quando o clima frio é mais intenso as abelhas africanizadas, ao invés de se aglomerarem, movimentam-se rapidamente para gerar energia adicional, provocando assim um aquecimento do micro-clima da colméia. As colônias se recuperam rapidamente no outono (diferentemente do que ocorre com as abelhas européias, cujo crescimento populacional é retomado na primavera), sendo que o período de enxameação das abelhas africanizadas coincide com a estação mais seca do ano (após o outono), geralmente entre julho e agosto.

As abelhas africanizadas podem produzir novos enxames quando ocorre grande oferta de alimento e a população for numerosa. As abelhas criam uma nova rainha e parte da colônia enxameia com a rainha mais velha, saindo à procura de um novo local de nidificação. Segundo Nascimento-Júnior (1981), no Brasil as colônias de abelhas africanizadas geralmente produzem enxames duas vezes por ano. No caso das abelhas européias, Seeley $(1977,1978)$ e Seeley e Morse (1978) verificaram que o número médio de enxames produzidos anualmente é 0,92 por colônia.

Um segundo mecanismo de dispersão observado nas abelhas africanizadas é decorrente da falta de alimento, condições climáticas desfavoráveis e/ou ameaça de predação da colônia. Nesse caso, todas as abelhas deixam a colméia e migram à procura de um local mais favorável para a construção de um novo ninho. No Estado de São Paulo, o primeiro tipo de comportamento (enxameação) ocorre entre agosto e outubro, enquanto o segundo (migração) é mais freqüente entre março e maio (SOARES et al., 1994). 
Pereira (2002) comparou o comportamento de abelhas italianas (Apis mellifera ligustica) e africanizadas no que se refere a algumas das tarefas da divisão de trabalho da colônia. O referido autor observou que as abelhas africanizadas apresentaram taxas de atividade menores em relação às italianas para os comportamentos de limpeza, inspeção e alimentação das crias. Nas tarefas de construção de favos e termorregulação, as abelhas italianas foram menos operantes em relação às abelhas africanizadas. No que se refere à atividade de recepção de alimento, água e própolis, as abelhas africanizadas e italianas trabalharam praticamente na mesma faixa etária. Contudo, houve diferença entre elas em relação à idade em que essas tarefas foram realizadas com maior intensidade. As abelhas africanizadas defenderam a colméia entre 14 e 18 dias e entre 22 e 26 dias de idade, enquanto as italianas executaram essa função do $22^{\circ}$ ao $30^{\circ}$ dia de vida, havendo um declínio acentuado na freqüência de abelhas guardas no $25^{\circ}$ dia, quando houve um aumento no número de abelhas africanizadas realizando essa tarefa. As abelhas italianas começaram a realizar coletas com 12 dias de idade, mas a fase principal de execução dessa atividade ocorreu entre $017^{\circ}$ e o $30^{\circ}$ dias de vida, com maior intensidade entre 25 e 30 dias de idade. As abelhas africanizadas trabalharam como coletoras do $16^{\circ}$ ao $30^{\circ}$ dia de vida, com maior frequiência entre 26 e 30 dias de idade.

Segundo Polischuk (1964), uma colméia é constituída internamente por dois conjuntos de fatores: os bióticos (população adulta: rainha, operárias e zangões; crias: ovos e operárias, rainhas e zangões em desenvolvimento) e os abióticos (cera, mel, pólen, própolis, secreções, temperatura, umidade e evaporação). Estes componentes estão inter-relacionados, atuam de forma contínua e não podem ser avaliados separadamente. Além disso, estão diretamente relacionados com as variáveis do meio ambiente.

Rizzini (1976) mencionou que as variáveis externas que atuam sobre a colônia são: 1) Fatores climáticos, ou seja, os elementos que constituem a atmosfera baixa, circundante, como os climas geral, local e o micro-clima (radiação solar, temperatura, precipitação pluviométrica, umidade relativa, vento e pressão atmosférica); 2) Fatores edáficos, como as características do solo próximo ao organismo, considerando como solo a camada superficial da crosta terrestre resultante da ação conjunta do clima, plantas, animais e minerais. Estas características são exemplificadas pela fração mineral, água, ar, matéria orgânica e organismo; 3) Fatores fisiográficos (também chamados de topográficos), que são derivados das condições de relevo, isto é, são fatores modificadores do clima e do solo e agem local ou regionalmente. Tais fatores são importantes na distribuição da flora apícola, porém têm pouca importância direta nas colônias de Apis mellifera; 4) Fatores bióticos, que são as diversas 
relações interespecíficas que envolvem os diferentes seres vivos. Existem muitas relações entre as abelhas Apis mellifera e outros organismos. As mais importantes são as relações desarmônicas de predação e parasitismo. Por outro lado, as relações consideradas harmônicas são as de simbiose entre as abelhas e as plantas.

Segundo Fukuda e Sakagami (1968), em uma colônia de Apis mellifera as operárias se concentram em maior número na região central dos favos, o que permite que a manutenção da temperatura seja realizada com maior eficiência. Os mencionados autores concluíram que o ideal é manter somente colônias populosas para que as operárias se distribuam regularmente sobre os favos, especialmente nas regiões onde existem ovos e abelhas em desenvolvimento, para que a viabilidade das crias seja garantida. Steiner (1947) e Ribbands (1953) verificaram que as operárias de Apis mellifera mantêm uma temperatura média de $35^{\circ} \mathrm{C}$ na região de crias. Quando a temperatura circundante diminui para $14^{\circ} \mathrm{C}$, ou menos, as abelhas se agrupam e formam verdadeiros aglomerados, constituindo uma massa esférica sobre as células de cria (PHILLIPS e DEMUTH, 1914 in MORITZ e SOUTHWICK, 1992). Desse modo, a temperatura dentro do aglomerado se mantém constante, independentemente da temperatura externa (CORKINS, 1930). Segundo Lindauer (1951), as abelhas adultas conseguem manter uma temperatura entre 34,5 e $35,5^{\circ} \mathrm{C}$ sobre as áreas de produção de crias. Contudo, ele verificou que durante o período de desenvolvimento as formas jovens podem sobreviver mesmo com uma variação de 32 a $36^{\circ} \mathrm{C}$.

Nascimento-Júnior (1981) observou que a umidade relativa é controlada pelas operárias coletoras. A água, que é trazida em grande quantidade para a colméia, é gotejada dentro das células de cria. Muitas operárias expõem, repentinamente, a probóscide e a movimentam sobre películas de água, formando grandes superfícies de evaporação. Em períodos de temperatura elevada a refrigeração interna do ninho é mantida pela ventilação realizada pela movimentação das asas das operárias, que possibilita a circulação do ar e aumenta a taxa de evaporação nas superfícies úmidas das próprias abelhas adultas, nas larvas e no mel estocado em células que ainda não foram operculadas.

Segundo Free (1980), a atividade de limpeza é um comportamento comum entre as abelhas. Sua frequência diminui à medida que as abelhas envelhecem, mas não desaparece totalmente. Abelhas recém-emergidas fazem sua própria limpeza corporal, um comportamento conhecido como autolimpeza. Algumas horas após a emergência, as operárias começam a limpar células que continham crias, retirando restos de casulos e resíduos fecais de seu interior e reparando as bordas irregulares das células que tiveram seus opérculos removidos. Essas tarefas são denominadas genericamente de limpeza de células. Além disso, 
limpam as abelhas mais velhas (de 4 a 20 dias) e retiram da colméia vários tipos de detritos, como opérculos velhos, abelhas e inimigos naturais mortos e grãos de pólen contaminados por fungos.

Abelhas de qualquer idade, que estão empenhadas nas tarefas inerentes à manutenção do ninho, freqüentemente limpam-se umas às outras. Além disso, limpam a rainha e os zangões. Quando uma abelha necessita de limpeza em algumas regiões do corpo que lhe são inacessíveis, como na base das asas e na constrição entre o tórax e o abdome, ela realiza uma movimentação corporal (dança do "grooming") durante a qual ela rapidamente bate as pernas e vibra seu corpo de um lado para o outro. Este procedimento fará com que uma abelha que esteja nas proximidades venha limpá-la (FREE, 1980). O "grooming” pode ser definido como o conjunto de atividades de limpeza corporal, realizadas entre os indivíduos de uma sociedade, que estabelece não só a comunicação, mas também o posicionamento hierárquico entre eles. Portanto, no que se refere à atividade de limpeza, cada operária da colônia realiza autolimpeza, limpeza de células, solicita limpeza, limpa outras abelhas e pode ser limpa por outra operária.

Com aproximadamente duas semanas de vida, as operárias de Apis mellifera começam a produzir cera, que é secretada por quatro pares de glândulas localizadas na superfície ventral do abdome (VERGERON, 1967). Whitcomb (1946) mencionou que para produzir aproximadamente meio quilo de cera é necessário que as operárias de diferentes colônias consumam de 3 a $4 \mathrm{~kg}$ de mel (3,8 kg em média). Segundo Taranov (1959), a produção de cera está relacionada com a quantidade de pólen consumido pelas operárias. O referido autor verificou que abelhas jovens, alimentadas unicamente com solução de açúcar, perderam $20 \%$ das proteínas de seu organismo em 15 dias de produção intensiva de cera. Com os dados que ele obteve foi possível estabelecer uma relação direta entre a quantidade de pólen coletada pelas abelhas e a quantidade de cera produzida pela colônia.

Free (1980) salientou que antes de iniciarem a atividade de coleta as operárias podem desempenhar a função de guarda, sendo que o número de abelhas que executam esta tarefa está relacionado com a quantidade de intrusos presentes nas imediações da colméia. O mesmo autor verificou que algumas operárias são responsáveis pelo patrulhamento em um determinado local do ninho, mas também podem se deslocar ou realizar atividade de coleta entre turnos de tarefa de guarda. Observou, ainda, que as abelhas que realizam esta importante atividade apresentam ovários mais desenvolvidos em relação às demais operárias da colméia.

Segundo Taranov e Sedin (1967), na fase de coleta de néctar as abelhas forrageiras podem apresentar três comportamentos distintos: 1. Dançam sobre um dos favos da colméia 
para atrair outras coletoras para a fonte de alimento (recrutamento); 2. Geralmente não há dança, mas as campeiras coletam ativamente o néctar; 3. Em determinado momento, uma grande quantidade de néctar está sendo transformada em mel e esta atividade mantém a maioria das abelhas ocupadas, fazendo com que o fluxo de coletoras ativas seja menos intenso. Estas fases podem ocorrer simultaneamente, mas nem sempre são típicas das atividades de todas as campeiras.

Butler e Calam (1969) salientaram que quase todas as espécies de Apis marcam as fontes de alimento com uma secreção produzida na glândula de Nasanov para aumentar sua atratividade, suplementando o odor floral com seu próprio cheiro. No entanto, as forrageiras de Apis mellifera geralmente só expõem a glândula de Nasanov depois de terem feito várias visitas à fonte de alimento, mesmo que esta seja abundante e atrativa (FREE, 1980). Este tipo de marcação é muito importante quando as fontes de néctar e pólen não possuem cheiro, mas é particularmente indispensável para a identificação das fontes de água (FREE e WILLIANS, 1970).

Em uma colônia de Apis mellifera o alimento é passado diretamente de uma operária para outra, bem como de operárias para a rainha e os zangões. Este processo é um mecanismo integrador importante para fortalecer as relações sociais entre os membros da colônia. O alimento transferido entre as abelhas é néctar, mel regurgitado do papo das operárias, secreções glandulares e água. Geralmente os indivíduos recebem alimento de abelhas mais velhas e a transferência deste alimento é uma conseqüência do ato de uma delas pedir ou oferecer alimento à outra. Durante a transferência de alimento as antenas do doador e do receptor estão em constante movimento, fazendo com que ambos mantenham contato íntimo (FREE, 1980).

A comunicação entre as abelhas é realizada por meio de sinais sonoros (sons típicos), mecânicos (danças) e químicos (odor e feromônios) (NEVES-FERMIANO, 1981). Apesar de a dança ser importante para indicar a direção que as abelhas recrutadas devem tomar para localizar a fonte de alimento descoberta pela operária coletora informante, o odor tem maior influência na orientação das abelhas, pois apenas 33\% da informação direcional é transmitida por meio da dança e 67\% pelo odor da fonte de alimento (GONÇALVES, 1969). Segundo Kerr (1974), as operárias de abelhas africanizadas realizam a dança do requebrado quando a fonte está a $25 \mathrm{~m}$, diferentemente das italianas (A. m. ligustica) que só começam a dançar quando a fonte se encontra a mais de 50m da colméia. Stort (1974) verificou que as abelhas africanizadas têm menor número de estruturas sensoriais nas antenas, quando comparadas com as italianas. O odor emitido pela fonte é muito importante para a sua localização. 
Segundo Gonçalves (1969), as abelhas africanizadas compensam sua menor sensibilidade em perceber o cheiro emanado pela fonte, dançando para transmitir a informação referente à sua localização, mesmo quando ela se encontra muito próxima da colméia.

Em pesquisas realizadas no Egito, Wafa e Ibrahim (1958) verificaram que durante o verão, período em que ocorre grande fluxo de néctar, o aumento da temperatura máxima estimulou a coleta de néctar e isto provocou um maior ganho de peso nas colméias de Apis mellifera. No inverno, época de escassez de néctar, o efeito da temperatura foi antagônico, ou seja, com o aumento da temperatura máxima houve uma diminuição no peso das colméias. Polischuk (1964) mencionou que a quantidade de néctar coletado pelas operárias depende das condições climáticas e diminui sob temperatura alta, umidade baixa, frio mais intenso, ventos secos e grande nebulosidade.

Segundo Jaycox (1970 a,b), a presença de rainha e crias exerce influência positiva na atividade forrageira, sendo que o comportamento de coleta de néctar é estimulado pela presença do feromônio de rainha (ácido 9-oxo-trans-2-decenóico), mas esta substância não influencia na coleta de pólen.

A atividade de forrageamento também pode ser influenciada pelo tamanho da colônia. Colônias menores geralmente apresentam maior número de abelhas coletoras (FREE e PREECE, 1969).

Em estudos realizados em plantações de milho, na cidade do Cairo, Ibrahim e Selin (1972) observaram que a elevação da temperatura causou um aumento na coleta de pólen, sendo que a atividade de coleta foi maior no período da manhã, entre 8 e 10 horas. $\mathrm{O}$ aumento da temperatura também teve influência na escolha da planta visitada pelas abelhas coletoras. Free (1967) verificou que a quantidade de pólen coletado pelas abelhas é progressivamente maior com o aumento do número de crias da colônia. O referido autor observou que a retirada das crias da colméia provocou uma diminuição na atividade de coleta de pólen e grande parte das abelhas coletoras desse recurso floral passou a coletar néctar.

Nye e Mackensen $(1965,1968,1970)$ e Mackensen e Nye $(1966,1969)$ verificaram que o comportamento de coleta de pólen de alfafa (Medicago sativa) por abelhas italianas (Apis mellifera ligustica) é controlado por vários poligenes com efeito aditivo. Os mencionados autores desenvolveram um programa de seleção para aumentar a frequência de operárias que coletavam somente este tipo de pólen e obtiveram um ganho de seleção de $87 \%$ depois de sete gerações de cruzamentos controlados, o que comprovou que o referido comportamento é fortemente influenciado pelo genótipo das abelhas. 
Malaspina (1982) estudou o comportamento de coleta de alimento de abelhas africanizadas, caucasianas (Apis mellifera caucasica) e dos descendentes obtidos dos cruzamentos entre elas e verificou que as primeiras são mais leves, transportam menor quantidade de xarope de sacarose, coletam maior quantidade de pólen e se deslocam mais rapidamente, tanto para alcançar a fonte de alimento, como para retornar à colméia. O referido autor obteve indícios de que as diferenças observadas entre as abelhas das colônias matrizes não endocruzadas e das parentais endocruzadas, no que se refere ao comportamento de coleta de xarope, eram influenciadas pelo genótipo das abelhas e também por fatores ambientais.

A utilização contínua das fontes alimentares é resultante da experiência que as abelhas adquirem por meio da aprendizagem paulatina e pelas informações que elas receberam anteriormente de outras coletoras da colméia (Thompson 1971). A atração das abelhas pelas diversas floradas está relacionada com a cor, forma, densidade, número e distribuição das espécies florais, velocidade do vento, posição do sol (WADDINGTON, 1983) e a quantidade, qualidade e concentração do néctar ou do pólen produzidos pela espécie vegetal considerada (FREE, 1980).

Segundo Lindauer e Schriker (1963) e Schriker (1965), a intensidade de luz do meio ambiente é medida pelas abelhas com muita exatidão. Elas são capazes de avaliar o tempo necessário para realizar o vôo de retorno à colméia, associando-o com a intensidade de luz existente em um determinado momento, antes de decidirem se devem ou não realizar um outro vôo de forrageio. Quando estão coletando a $50 \mathrm{~m}$ da colméia, trabalham até a intensidade de luz ser reduzida para 2 lux. Por outro lado, quando as coletas são realizadas em locais mais distantes (de 3 a 4km), elas retornam à colméia quando a intensidade luminosa é reduzida para 8 lux.

Nuñez (1977) observou que a atividade de vôo de operárias de Apis mellifera ligustica está correlacionada com o fotoperiodismo. No período matutino ela depende principalmente do fluxo de néctar. No período vespertino ocorre diminuição na coleta de néctar devido ao aumento da velocidade do vento e da temperatura.

Estudando o comportamento de coleta de xarope de sacarose por abelhas africanizadas e européias em fontes artificiais de alimento, Gonçalves et al. (1972) verificaram que as primeiras permanecem menos tempo no alimentador em relação às últimas. Por outro lado, Beig et al. (1972) observaram que as africanizadas coletam menor quantidade de xarope por viagem do que as italianas (A. m. ligustica) e sugeriram que estas têm uma economia baseada em um nível energético mais elevado. Segundo os referidos autores, esta característica seria desfavorável em períodos de escassez de alimento e, portanto, poderia explicar a rápida 
expansão das abelhas africanizadas no Brasil. Contudo, Neves - Fermiano (1981) mencionou que a carga de xarope de sacarose que as operárias de abelhas africanizadas transportam em cada visita à fonte artificial de alimento é maior do que o seu próprio peso corporal.

Nuñez (1974) observou que mesmo quando o fluxo de néctar é baixo, as operárias de A. m. ligustica continuam a coletar, diferentemente das operárias de abelhas africanizadas que deixam de visitar a fonte de alimento. O referido autor verificou também que embora as africanizadas transportem uma menor quantidade de alimento em cada viagem de coleta, elas compensam esta suposta deficiência realizando um maior número de visitas à fonte. Segundo ele, o fato de as africanizadas realizarem várias viagens representa uma vantagem significativa para a colônia, considerando que em cada visita à fonte elas podem recrutar um maior número de abelhas coletoras.

Maurizio (1950) sugeriu que o tempo de vida das operárias de Apis mellifera depende da quantidade de pólen que elas consomem, mas também é influenciado pelo número de crias presentes na colméia.

Free e Spencer-Booth (1959) estudaram as variações nas taxas de mortalidade de operárias de abelhas italianas (Apis mellifera ligustica) nos Estados Unidos da América do Norte, tendo concluído que as diferenças observadas dependiam da estação do ano considerada. Segundo eles, as operárias nascidas na primavera apresentaram um aumento na expectativa de vida em relação às emergidas no verão. Além disso, durante uma mesma estação, as diferenças entre várias colônias eram decorrentes de variações na quantidade de crias existente em cada uma delas. Os referidos autores salientaram que outros fatores, como o tamanho da colônia, a temperatura do ninho, o grau de nutrição das abelhas e a sua atividade metabólica também devem ter influência sobre a longevidade.

Outros autores, como Lints (1981), Eischen et al. (1982) e Couto e Nogueira-Couto (1990), afirmaram que a longevidade é influenciada por variáveis ambientais. Em pesquisas realizadas no Japão, Sakagami e Fukuda (1968) verificaram que as abelhas emergidas nos meses de intensa atividade de coleta de alimento viveram de 28,3 a 32,4 dias, enquanto que aquelas nascidas no inverno sobreviveram, em média, 154,1 dias. Southwick et al. (1990) observaram que, durante o inverno, as abelhas africanizadas apresentam uma elevada taxa metabólica devido à manutenção da temperatura interna da colméia, tendo concluído que esta atividade reduz a longevidade das abelhas.

Por outro lado, existem várias evidências de que a longevidade das operárias seja condicionada geneticamente, podendo ser aumentada por seleção dirigida (RINDERER e SILVESTER, 1978; MILNE, 1980, 1985; KULINCEVIC e ROTHENBHLER, 1982). 
Embora Winston e Katz (1981) e Sommer (1986) tenham detectado algumas diferenças significativas entre linhagens de abelhas européias e africanizadas, ainda existe muita controvérsia sobre o possível controle genético da longevidade.

Winston (1988) observou que as operárias de abelhas africanizadas apresentaram menor longevidade (de 12 a 18 dias) em relação às abelhas européias (de 15 a 38 dias), durante os períodos de grande fluxo de néctar. No inverno as africanizadas viveram, em média, 90 dias, enquanto as européias sobreviveram durante 140 dias. Segundo o referido autor, a diminuição de longevidade das abelhas africanizadas é uma consequiência do maior desgaste físico e energético que elas sofrem, por iniciarem as atividades diárias de coleta mais cedo e terminarem mais tarde em relação às abelhas européias. Em um trabalho realizado anteriormente, Kerr et al. (1970) já haviam destacado este comportamento peculiar das abelhas africanizadas.

A cafeína é um alcalóide lipossolúvel, integrante da classe dos compostos conhecidos como metilxantinas (D’AMICIS e VIANI, 1993). Sua estrutura química é 1,3,7trimetilxantina e foi verificado que ela atua no sistema nervoso central (ALBINA et al., 2002). O isolamento original da cafeína foi realizado em 1820, por Runge, e o primeiro estudo desenvolvido para avaliar seus efeitos no metabolismo ocorreu em 1850 (JACOBSON e KULLING, 1989).

Segundo Ritchie (1975), a cafeína é um ingrediente que se tornou muito comum na alimentação humana porque é encontrada em um grande número de produtos naturais e industrializados. Ela é um constituinte natural das nozes, sementes de cacau (Theobroma cacau), folhas de chá-mate (Ilex paraguariensis St. Hilaire), grãos de café (Coffea arabica) e guaraná (Paullinia cupana Kunth) (WOLINSKY e HICKSON Jr., 1996), estando presente em vários alimentos, bebidas e refrigerantes, particularmente naqueles com denominação "cola", bem como na composição de alguns medicamentos, como antigripais e analgésicos, pelo fato de ser um eficiente estimulante natural (BENOWITZ, 1990; NEHLING et al., 1992; DALY, 1993).

A cafeína foi encontrada em mais de 60 espécies de plantas e o número de produtos que contêm essa substância é muito grande, fazendo com que ela seja, seguramente, a droga psicoativa mais popular no mundo (GLASS, 1994; PALFAI e JANKIEWIEZ, 1991).

O café atualmente é a fonte de cafeína mais importante na dieta humana. Além do café, a cafeína é encontrada no chocolate e no chá-mate, uma bebida consumida em grande escala em países sul-americanos. Por este motivo, seu uso passou a ser indiscriminado, 
atingindo consumidores de todas as idades e crescendo gradativamente nos últimos anos, particularmente entre as pessoas idosas e de meia idade (D'AMICIS e VIANI, 1993).

Quando ingerida oralmente é rapidamente absorvida pelo trato gastrointestinal, atingindo seus níveis de pico, no plasma, entre 30 e 120 minutos (SAWYNOK e YAKSH, 1993).

A cafeína apresenta três mecanismos principais de ação: 1) mobilização intracelular do cálcio do retículo sarcoplasmático; 2) inibição de fosfodiesterases em vários tecidos, como músculos e adipócitos; e 3) antagonismo em relação aos receptores de adenosina, principalmente no sistema nervoso central (NEHLING e DEBRY, 1994).

Estudos desenvolvidos em seres humanos revelaram que a cafeína produz efeitos subjetivos e comportamentais que são similares àqueles típicos de drogas psicomotoras estimulantes, conhecidas por serem mediadas dopaminergicamente, como as anfetaminas e a cocaína (GARRET e GRIFFITHIS, 1997; MINATTI, 2002). Segundo Tarnopolsky (1994) e Pasman (1995), o Comitê Olímpico Internacional (COI) classificou a cafeína como uma droga restrita em concentrações acima de $12 \mathrm{mg} / \mathrm{L}$, pois sua detecção se torna positiva na urina.

A interrupção da dosagem depois de uma administração crônica diária de cafeína produz síndrome de abstinência, como foi demonstrado pela interrupção de resposta operante (CARNEY, 1982) e diminuição da atividade locomotora espontânea (HOLTZMAN, 1983; FINN e HOLTZMAN, 1986), o que caracteriza uma evidência de dependência física. Os principais componentes da abstinência de cafeína são o aumento da fadiga e a sonolência (STRINGER e WATSON, 1987; GRIFFITHIS e WOODSON, 1988; GRIFFITHIS e MUMFORD, 1995; GRIFFITHIS et al., 1990), que são sintomas proeminentes da síndrome de abstinência de anfetaminas e cocaína (SHILDKRAUT et al., 1971; WATSON et al., 1972, 1992).

Os resultados dos estudos epidemiológicos sobre o potencial reprodutivo e a toxicidade da cafeína no desenvolvimento de camundongos não têm sido consistentes (ALBINA et al., 2002). No caso de seres humanos, algumas observações foram realizadas em relação aos efeitos nocivos da cafeína sobre o crescimento fetal (ESKENAZI et al., 1999) e, segundo alguns autores, estes malefícios ocorrem se a cafeína estiver associada ao hábito de fumar ou de ingerir bebidas alcoólicas (VLAJINAC et al., 1997).

Segundo Fredholm (1995), estudos pré-clínicos realizados com cafeína sugerem que o efeito estimulante no comportamento pode ser decorrente do aumento da atividade de neurotransmissão dopaminérgica, talvez devido à interação entre dopamina e adenosina (DA). Devido a uma redução na retomada de cálcio nas vesículas microssômicas, a cafeína mobiliza 
o cálcio intracelular nos neurônios e estimula a liberação deste elemento no retículo endoplasmático (MEKHAIL-ISHAK et al., 1987). Daly (1993) salientou que o aumento da concentração de cálcio intracelular é importante para a liberação dos neurotransmissores (dopamina), enquanto sua mobilização no interior da célula pode ser o mecanismo responsável pelos efeitos comportamentais da cafeína.

Em Vespa orientalis, a cafeína impede a hibernação de rainhas jovens, provoca um aumento na atividade sexual de rainhas e machos, na taxa de postura de rainhas fecundadas, bem como na oviposição de operárias poedeiras (ISHAY e PANIRY, 1979). Segundo estes mesmos autores, talvez os apicultores possam fazer uso da cafeína quando quiserem aumentar a taxa de oviposição de rainhas jovens fecundadas, durante uma estação particular, por exemplo, um pouco antes da primavera.

Itoyama e Bicudo (1992) analisaram os efeitos da cafeína na fecundidade, capacidade de oviposição, velocidade do desenvolvimento ovo-adulto e na longevidade dos indivíduos adultos de Drosophila prosaltans. Quatro concentrações de cafeína (50, 100, 1000 e $1500 \mu \mathrm{g} / \mathrm{mg}$ ) foram acrescentadas ao meio de cultura fornecido a estes insetos e notou-se que a fecundidade e a taxa de oviposição diminuiram com o aumento da dose utilizada. Também foi observado um aumento de um dia no tempo de desenvolvimento das moscas, para as concentrações correspondentes a 1000 e $1500 \mu \mathrm{g} / \mathrm{mg}$. Além disso, houve redução na longevidade das fêmeas, machos virgens e machos que realizaram acasalamento. Na maioria dos experimentos realizados, as fêmeas fecundadas, tratadas com dieta contendo cafeína, apresentaram maior longevidade em relação às moscas do grupo controle. Segundo os autores da pesquisa, esse resultado pode indicar certo benefício do bloqueio parcial da oviposição, decorrente do tratamento com cafeína.

Sehgal e Simões (1976) realizaram um estudo preliminar sobre o efeito de algumas drogas neutrópicas (cafeína, barbiturato de sódio, ácido glutâmico, anafranil e fosfato de codeína) em Drosophila melanogaster. O tratamento com estas drogas foi realizado a partir da fase de ovo e durante o desenvolvimento larval. Os mencionados autores observaram que o desenvolvimento das larvas não foi retardado. Contudo, as fêmeas adultas, na maioria dos casos, apresentaram esterilidade e malformações dos ovários. Dentre as drogas testadas em larvas de primeiro ínstar, a cafeína foi a mais tóxica.

Segundo Sehgal et al. (1977), a cafeína causou um severo atraso no crescimento e desenvolvimento de Telmatoscopus albipunctatus, além de uma elevada taxa de mortalidade larval. De um modo geral, a sensibilidade à cafeína foi inversamente proporcional à idade das larvas submetidas ao tratamento utilizado no experimento. As larvas que receberam a dieta 
contendo cafeína se desenvolveram em adultos com menor grau de fertilidade. As pupas tratadas apresentaram abdômens alongados, asas anormais e fertilidade reduzida na fase adulta. A cafeína também afetou, de forma negativa, a politenização dos cromossomos. Os autores da pesquisa sugeriram que os efeitos da cafeína observados no crescimento larval e na politenização cromossômica devem-se a um atraso na síntese de DNA.

Laperuta (2005) estudou o efeito da cafeína sobre a taxa de oviposição de operárias órfãs de abelhas africanizadas (Apis mellifera). Uma colônia parental foi dividida em duas populações contendo aproximadamente o mesmo número de abelhas e condições semelhantes de manutenção e alimentação. Estas populações foram mantidas em estado de orfandade, sendo uma delas alimentada semanalmente com xarope de sacarose (1:1) contendo cafeína, enquanto a outra (grupo controle) recebeu apenas xarope. O tratamento alimentar foi realizado durante 4 meses consecutivos e, neste período, a referida pesquisadora comparou o desenvolvimento ovariano das operárias e o número de ovos presentes em células de favos de crias das duas colméias. A análise dos gráficos de frequiência dos tipos de ovários das operárias e do desenvolvimento ovariano em 6 faixas etárias (15, 20, 25, 30, 35 e 40 dias), revelou que a cafeína acelerou o desenvolvimento dos ovários das operárias e inibiu, temporariamente, a degeneração destes órgãos. A comparação dos dados referentes ao número de ovos depositados nas células dos favos de crias das duas colônias indicou que as operárias alimentadas com a dieta contendo cafeína depositaram mais ovos em relação às abelhas do grupo controle, em duas das três amostras de células examinadas. Assim sendo, a autora da pesquisa concluiu que a cafeína acelera o desenvolvimento ovariano e aumenta a taxa de oviposição nas operárias de abelhas africanizadas órfãs. 


\section{OBJETIVOS}

Esta pesquisa teve por objetivo verificar a influência da cafeína nas atividades referentes à divisão de trabalho entre operárias de abelhas africanizadas (Apis mellifera L.) de diferentes idades, bem como na longevidade dessas abelhas.

Adicionalmente, estudou-se a relação entre o comportamento de coleta e as variáveis ambientais: índice pluviométrico $(\mathrm{mm})$, pressão atmosférica $(\mathrm{mb})$, temperatura $\left({ }^{\circ} \mathrm{C}\right)$, umidade relativa do ar $(\%)$ e velocidade do vento $(\mathrm{Km} / \mathrm{h})$. 


\section{MATERIAL E MÉTODOS}

Para o desenvolvimento deste estudo foram utilizadas duas colméias de observação. Cada colméia possuía uma rainha africanizada recém-fecundada em vôo livre, em franca postura, e dois favos cobertos por abelhas africanizadas, sendo um deles provido de mel e pólen e o segundo com larvas em diferentes fases de desenvolvimento. Uma das populações (grupo controle) foi alimentada, semanalmente, com $50 \mathrm{~g}$ de cândi ( $85 \%$ de glaçúcar $+15 \%$ de mel), enquanto a outra (grupo experimental) recebeu 49,67g de cândi misturado a $0,33 \mathrm{~g}$ de cafeína, segundo a metodologia utilizada por Laperuta (2005).

Operárias recém-emergidas, provenientes de uma colônia matriz de abelhas africanizadas (Apis mellifera L.), localizada no apiário do campus da UNESP, em Rio Claro SP (Figura 1), contendo uma rainha fecundada em vôo livre, foram marcadas com discos plásticos numerados colados ao tórax (Figura 2), segundo a técnica descrita por Pereira e Chaud-Netto (2008), sendo posteriormente introduzidas nas duas colméias de observação (Figura 3).

No período de janeiro a maio de 2007 foram realizadas as observações e o registro das principais atividades referentes à divisão de trabalho entre operárias de abelhas africanizadas alimentadas com e sem cafeína. Também foi registrada a longevidade das operárias dos dois grupos estudados. De dois em dois dias, 20 operárias marcadas foram introduzidas em cada colméia, utilizando-se, para isso, uma tela metálica de 2 × 10 × $20 \mathrm{~cm}$ de dimensões, com malha de $1 \mathrm{~mm}^{2}$ (PEREIRA, 2002). A introdução periódica de operárias marcadas teve por objetivo assegurar que, depois de algum tempo, houvesse abelhas de todas as idades em cada colônia. Cada grupo de operárias foi liberado 24 horas após a introdução para que as abelhas 
que já estavam presentes nas colméias pudessem se acostumar com as recém-introduzidas. A partir desse momento, as abelhas foram observadas dia após dia no período das 6 às 18 horas. Os comportamentos foram observados em intervalos de uma hora e com revezamento entre as colméias, em relação ao início das observações e no decorrer do dia.

As atividades analisadas nesta pesquisa foram: inspeção de células, limpeza (autolimpeza, limpeza de células e limpeza de outras operárias), termorregulação, construção de células, recepção de alimento, coleta de recursos (pólen e néctar), defesa da colônia e alimentação das larvas e da rainha. O mesmo procedimento foi adotado nos grupos controle (dieta normal) e experimental (dieta contendo cafeína). Ao todo foram observadas 606 operárias em cada colônia. Os resultados obtidos na pesquisa foram comparados para se avaliar a influência da cafeína no comportamento das operárias.

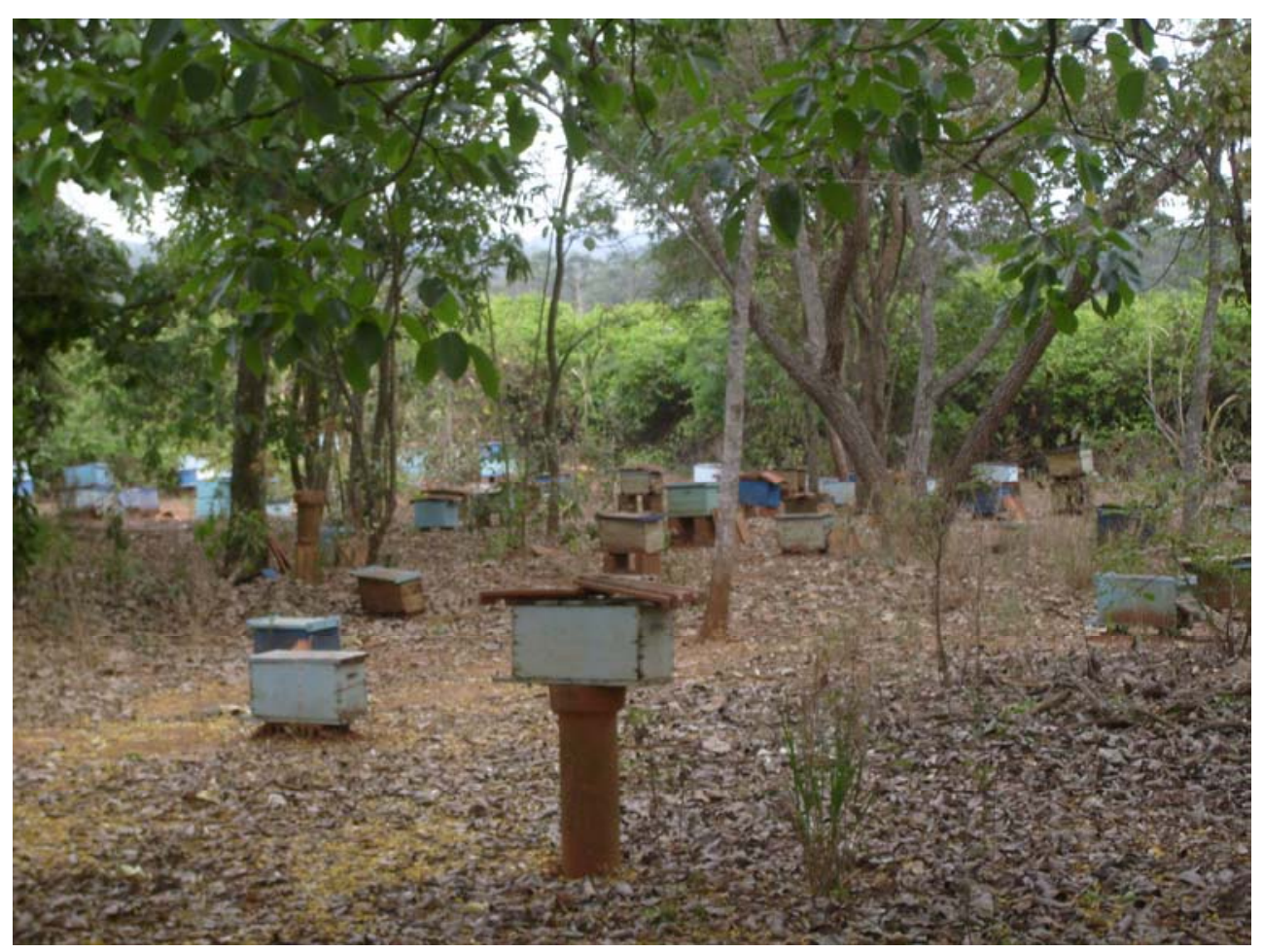

Figura 1. Apiário localizado no campus da Universidade Estadual Paulista "Júlio de Mesquita Filho", em Rio Claro - SP, onde se localiza a colônia matriz de onde foram retiradas as operárias recém-emergidas para marcação e posterior introdução nas colméias de observação instaladas no laboratório do biotério. 

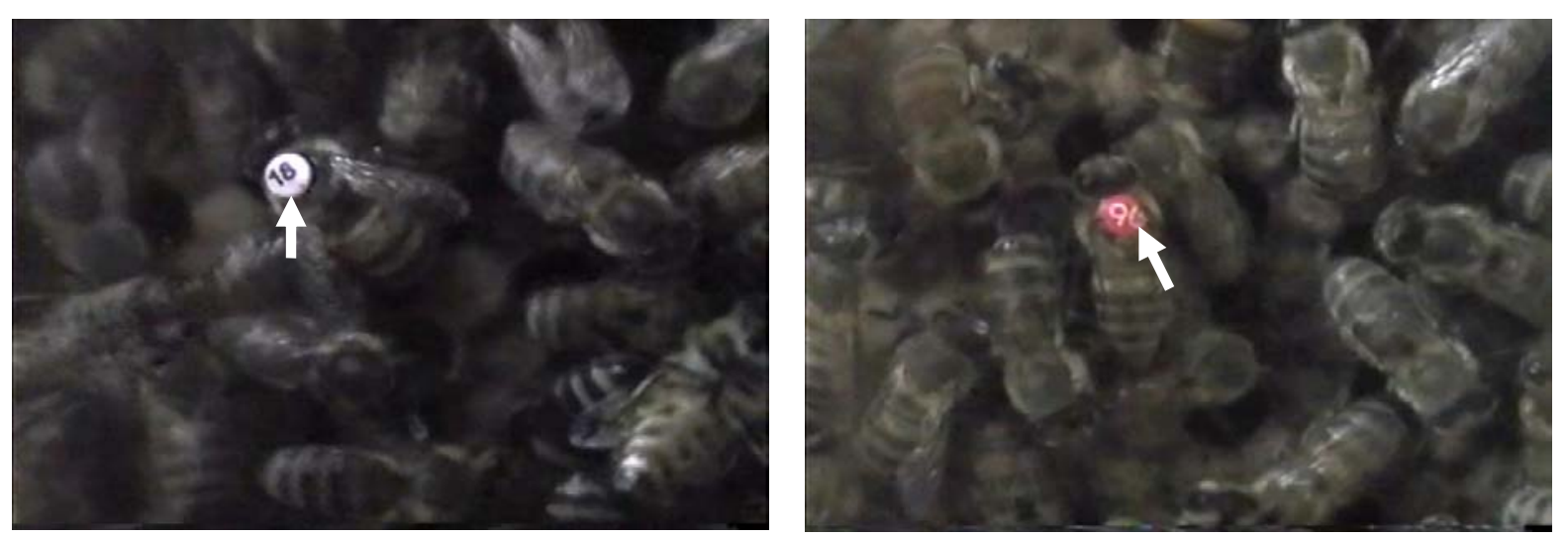

Figura 2. Operárias de Apis mellifera marcadas com disco plástico numerado, segundo a técnica descrita por Pereira e Chaud-Netto (2008).

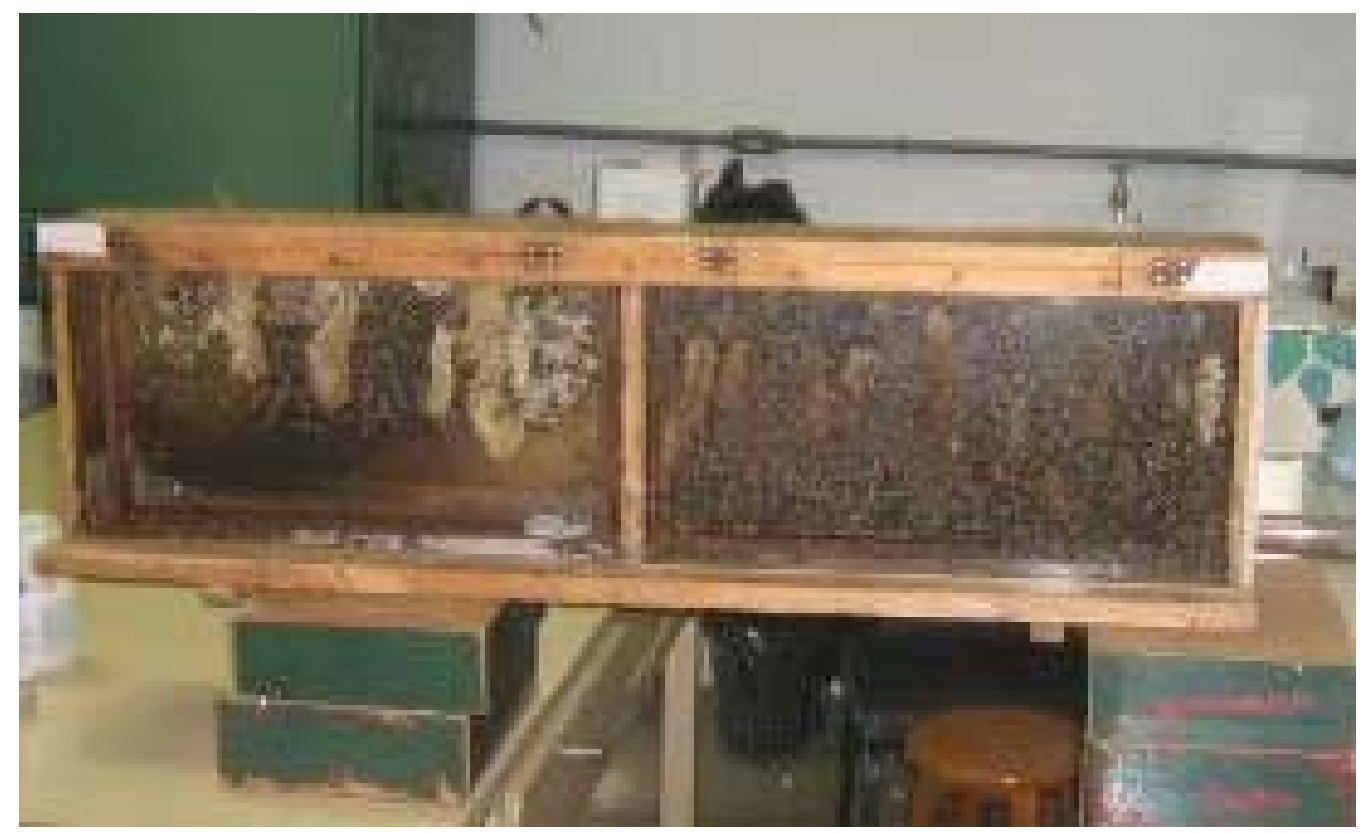

Figura 3. Vista geral de uma das colméias de observação utilizadas para estudar o comportamento das operárias de Apis mellifera L.

Para possibilitar a observação e o registro diário do tipo de recurso alimentar, que as operárias de Apis mellifera L. carregavam na chegada ao ninho (néctar ou pólen), foi necessário acoplar, a cada uma das colméias (grupos controle e experimental), um tubo plástico transparente conectado a uma caixa de madeira de 10x10x5 cm de dimensões, com tampa de vidro (Figuras 4, 5 e 6). 


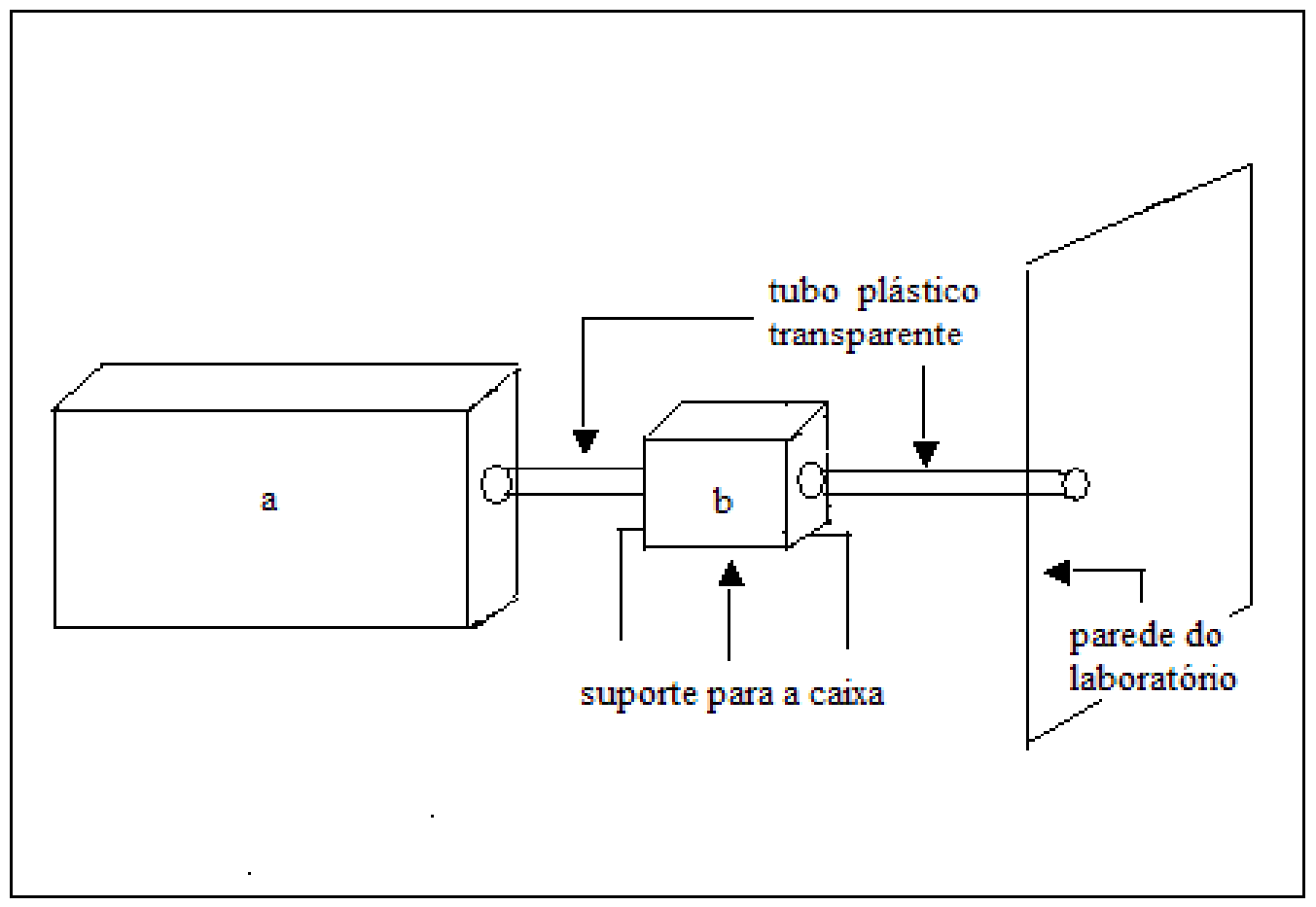

Figura 4. Esquema da colméia de observação (a) e da caixa de madeira (b) utilizadas para registrar a atividade coleta de recursos alimentares por operárias de Apis mellifera L.

Para verificar se a cafeína exerce alguma influência na construção de novas células no favo de crias, os favos recém-construídos foram observados e filmados, semanalmente, para que o número de células elaboradas pelas operárias das duas colônias pudesse ser registrado e comparado.

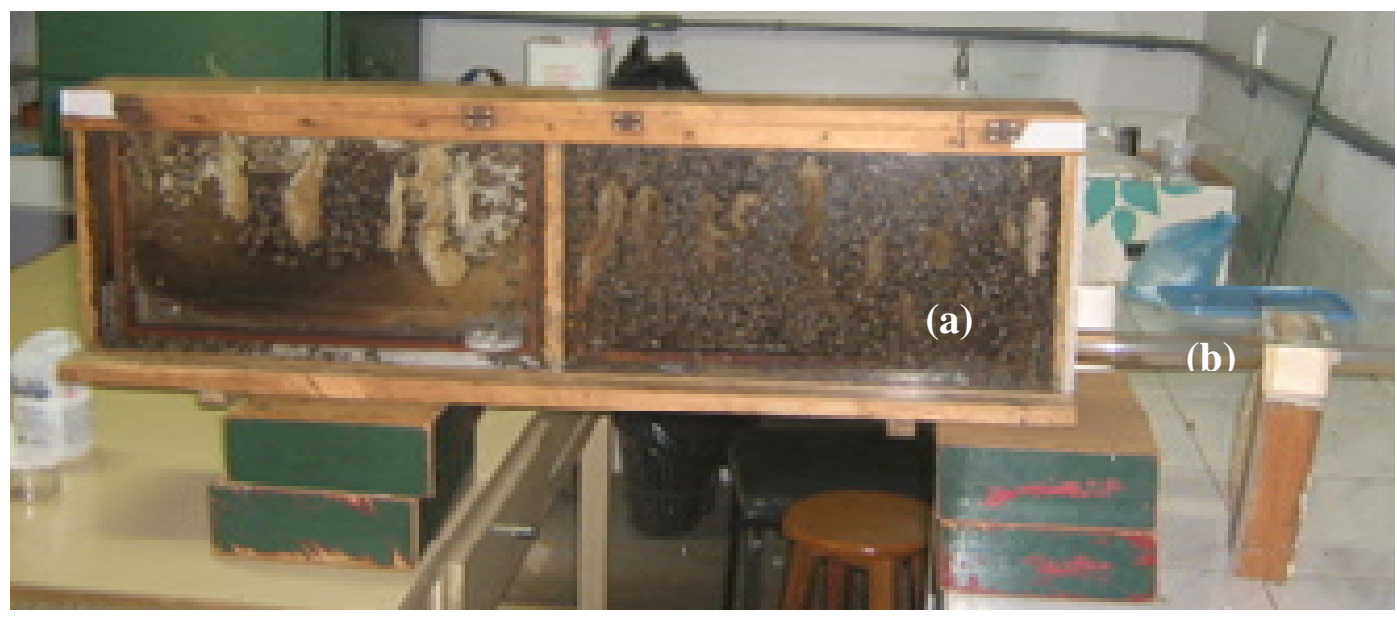

Figura 5. Vista geral da colméia de observação (a) e da caixa de madeira (b) utilizadas para registrar a atividade de coleta de recursos alimentares por operárias de Apis mellifera L.. 

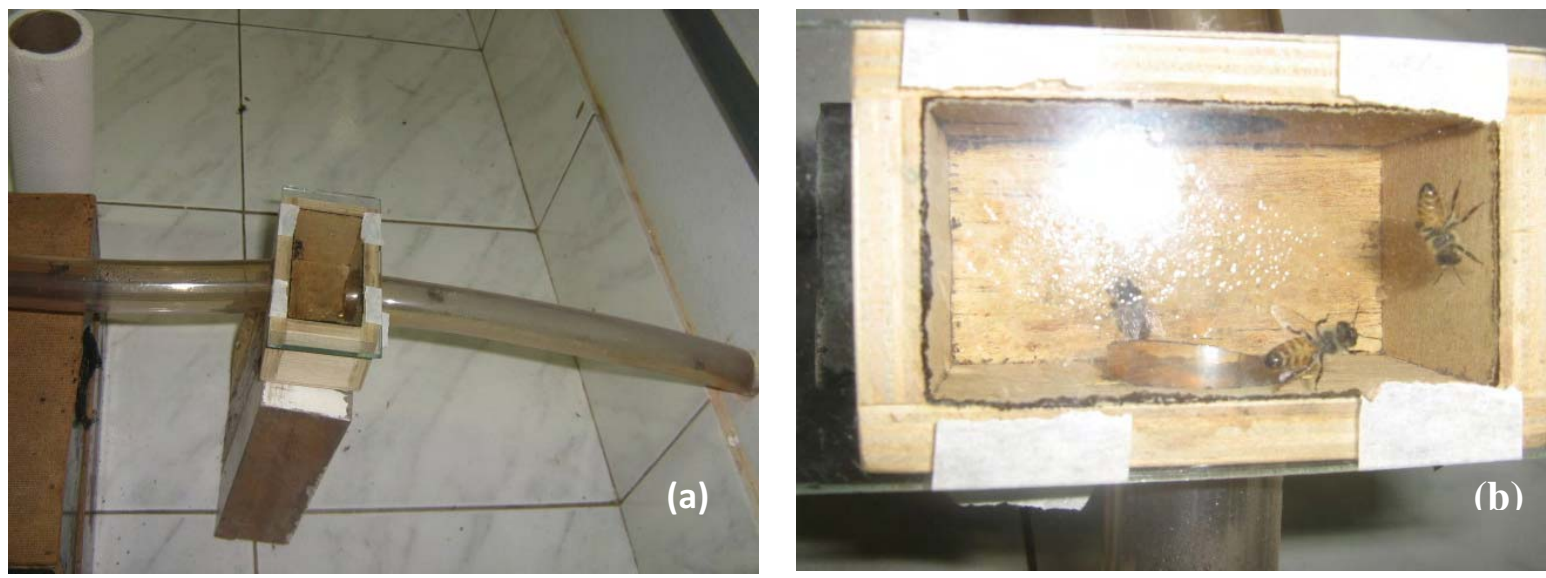

Figura 6. Vista da caixa de madeira acoplada à colméia de observação instalada no biotério: (a) vista geral; (b) vista superior.

\subsection{Análise dos resultados obtidos}

Os dados referentes às atividades desenvolvidas pelas operárias do grupo experimental e do grupo-controle (limpeza, inspeção de célula, termorregulação, construção de célula, coleta de recursos, recepção de alimento, defesa da colônia e alimentação larval) foram inicialmente submetidos a uma análise descritiva para verificar se apresentavam distribuição normal e variâncias homogêneas. O teste não paramétrico U de Mann-Whitney foi utilizado para comparar os resultados obtidos para os dois grupos de abelhas, pois a análise descritiva revelou que eles não apresentavam distribuição normal.

O efeito da cafeína na longevidade das operárias foi avaliado por meio do registro do tempo de permanência das abelhas marcadas nas duas colméias de observação. Para isso, foi realizado o registro diário dessas abelhas em cada colônia. Os dados obtidos para as abelhas dos dois grupos foram posteriormente comparados.

Adicionalmente, foi avaliada a relação entre a longevidade, a atividade de coleta de recursos, a entrada e saída do ninho, e as variáveis ambientais, por meio da Análise de Correlação de Spearman (rs). Os dados referentes ao índice pluviométrico ( $\mathrm{mm}$ ), pressão atmosférica $(\mathrm{mb})$, temperatura $\left({ }^{\circ} \mathrm{C}\right)$, umidade relativa do ar $(\%)$ e velocidade do vento $(\mathrm{km} / \mathrm{h})$ foram gentilmente fornecidos pela Estação Meteorológica de Rio Claro (CEAPLA/IGCE/UNESP). 


\section{RESULTADOS E DISCUSSÃO}

\subsection{Descrição do Comportamento de Abstinência}

As abelhas pertencentes ao grupo experimental apresentaram alterações comportamentais em relação às abelhas do grupo controle. Quando o cândi contendo cafeína era administrado à colônia, formava-se um aglomerado de abelhas ao redor do alimentador, e o alimento era consumido entre 24 e 48 horas (2,42 \pm 0,40 dias). Quando o cândi acabava, muitas operárias que o haviam ingerido retornavam ao alimentador em busca de mais alimento. Na colônia utilizada como grupo controle, a mesma quantidade de cândi oferecida às abelhas (sem cafeína) demorava aproximadamente cinco dias $(5,58 \pm 0,23$ dias $)$ para ser consumida pelas operárias. As operárias que apresentaram comportamento de abstinência, devido ao uso excessivo de cafeína, representaram 13\% $(\mathrm{n}=78)$ das abelhas da população do grupo experimental e apresentaram uma longevidade média de 15,44 \pm 1,19 dias, com número médio de indivíduos igual a 8,67 \pm 1,03 e longevidade máxima de 31 dias (Tabela 1).

Em seres humanos sabe-se que a cafeína atua no aumento da dopamina no sangue, por diminuir sua recepção no sistema nervoso central. A dopamina também é um neurotransmissor (relacionado ao prazer) e suspeita-se que seja justamente este aumento dos níveis da dopamina que leve à dependência da cafeína (MINATTI, 2002).

Algumas abelhas pertencentes ao grupo experimental desenvolveram sintomas de abstinência, tais como compulsão, agitação, alterações de sensibilidade no tegumento, falta de coordenação motora e tremores (resultantes da tensão muscular crônica), que prejudicam a 
estabilidade dos membros. Estudos psicofarmacológicos têm demonstrado que a dependência física da cafeína pode ocorrer com seu uso persistente (GRIFFITHIS et al., 1986, 1990).

As operárias com síndrome de abstinência, após três ou quatro passos, apresentavam tremores por todo o corpo e, em seguida, repetiam o mesmo tipo de comportamento. Além disso, ao realizar algumas atividades internas do ninho desenvolveram comportamento compulsivo, como ocorreu na execução da tarefa de autolimpeza. Outras abelhas não conseguiram completar determinadas atividades como termorregulação e dança, devido à agitação e falta de coordenação motora. É provável que a crise de abstinência tenha causado aumento na sensibilidade do tegumento, pois as operárias constantemente realizavam autolimpeza e solicitavam limpeza corporal a outras abelhas.

As operárias em estado de abstinência tentaram várias vezes acompanhar a dança de algumas campeiras, mas não conseguiram completar o processo. Além disso, $100 \%$ das abelhas dependentes da cafeína realizaram constantes contatos antenais com outras operárias (antenação), 24 horas antes de sua morte.

\subsection{Divisão de trabalho entre operárias de diferentes idades}

\section{Atividade de Limpeza}

A atividade de limpeza representou $7 \%$ de todas as atividades desenvolvidas pelas operárias do grupo controle e $12 \%$ das tarefas registradas para as abelhas do grupo experimental. Considerando as funções envolvidas na atividade de limpeza, verificou-se que as operárias dos dois grupos passaram a maior parte do tempo realizando autolimpeza (62\% das abelhas no grupo controle e 65\% no grupo experimental), com 2.211 e 2.109 observações realizadas, respectivamente. Também foi observado que as abelhas do grupo experimental trabalharam um pouco menos na limpeza de células (11\% delas) e de outras operárias (15\%), em relação às abelhas do grupo controle (12\% e $17 \%$, respectivamente) (Tabela 1). 


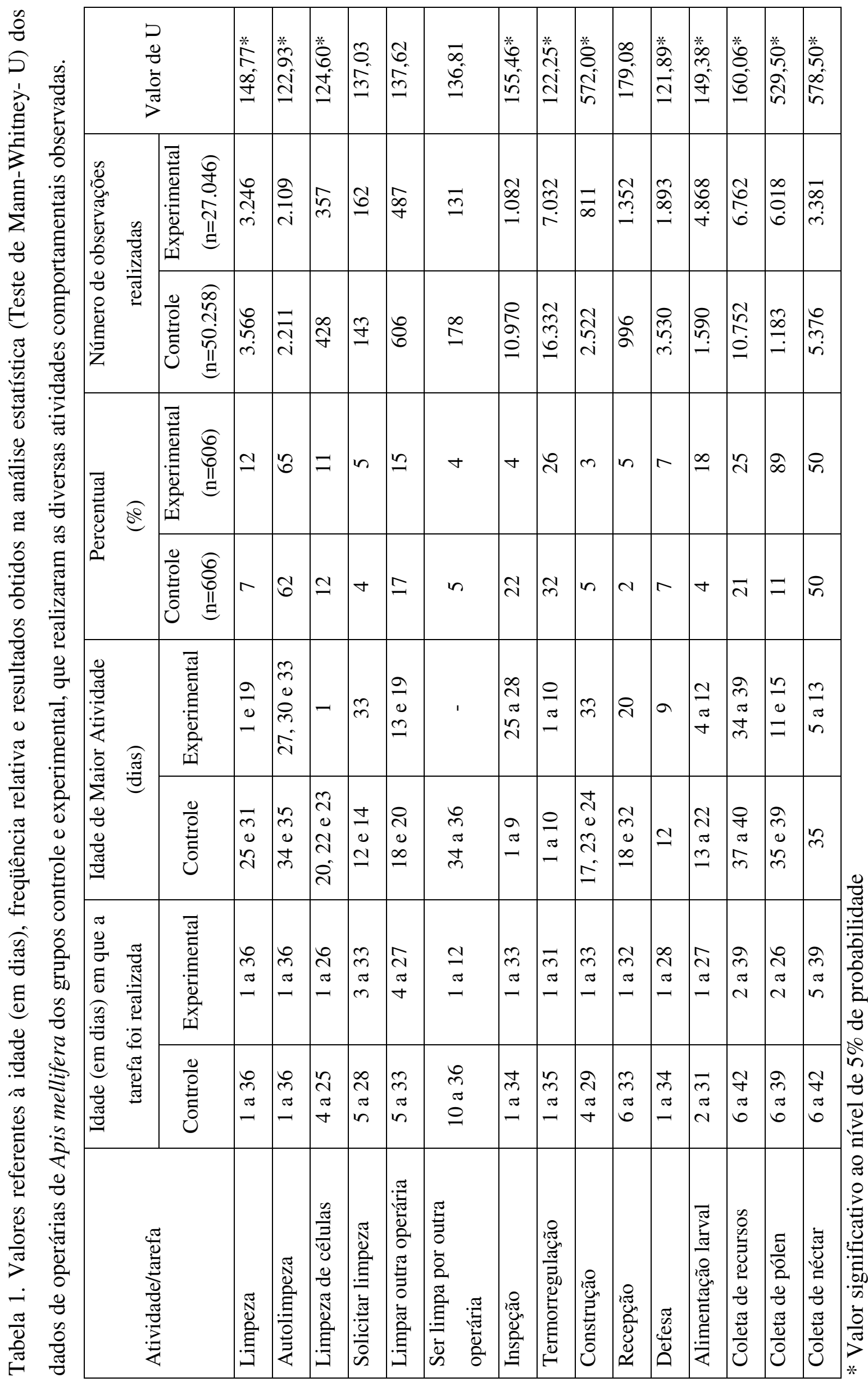


Uma análise dos dados obtidos na pesquisa revelou que o período de atividade de limpeza ocorreu entre 1 e 36 dias de idade, para os dois grupos estudados. No grupo controle, a freqüência relativa de operárias realizando atividades de limpeza variou de 2 a 16\%, enquanto que no grupo experimental registrou-se uma variação de 1 a 30\%. As abelhas do grupo controle foram mais ativas com 25 e 31 dias de vida (picos de atividade de 15\%), enquanto as operárias do grupo experimental apresentaram um pico de atividade (29\%) logo no primeiro dia de idade e um segundo pico (30\%) no $19^{\circ}$ dia de vida (Figura 7 e Tabela 1).

Com relação à atividade de limpeza, considerando simultaneamente as tarefas de autolimpeza, limpeza de células e limpeza de operárias, a análise estatística comparativa dos dados obtidos para as operárias dos dois grupos utilizados nesta pesquisa indicou um resultado significativo $(\mathrm{U}=148,77 ; \mathrm{p}<0,0001)$, sendo que as abelhas do grupo experimental realizaram esta atividade com maior frequência em relação às abelhas do grupo controle. No entanto, uma análise comparativa individual das tarefas referentes à atividade de limpeza realizada pelas operárias dos dois grupos indicou diferenças significativas no número de abelhas que fizeram autolimpeza $(U=122,93 ; p=0,0004)$ e limpeza de células $(U=124,60$; $\mathrm{p}=0,0015)$. Para as demais tarefas, como: solicitar limpeza $(U=137,03 ; \mathrm{p}=0,4923)$, limpar outra operária $(U=137,62 ; p=0,5696)$ e ser limpa por operária $(U=136,81 ; p=0,4654)$ não houve diferença significativa (Tabela 1).

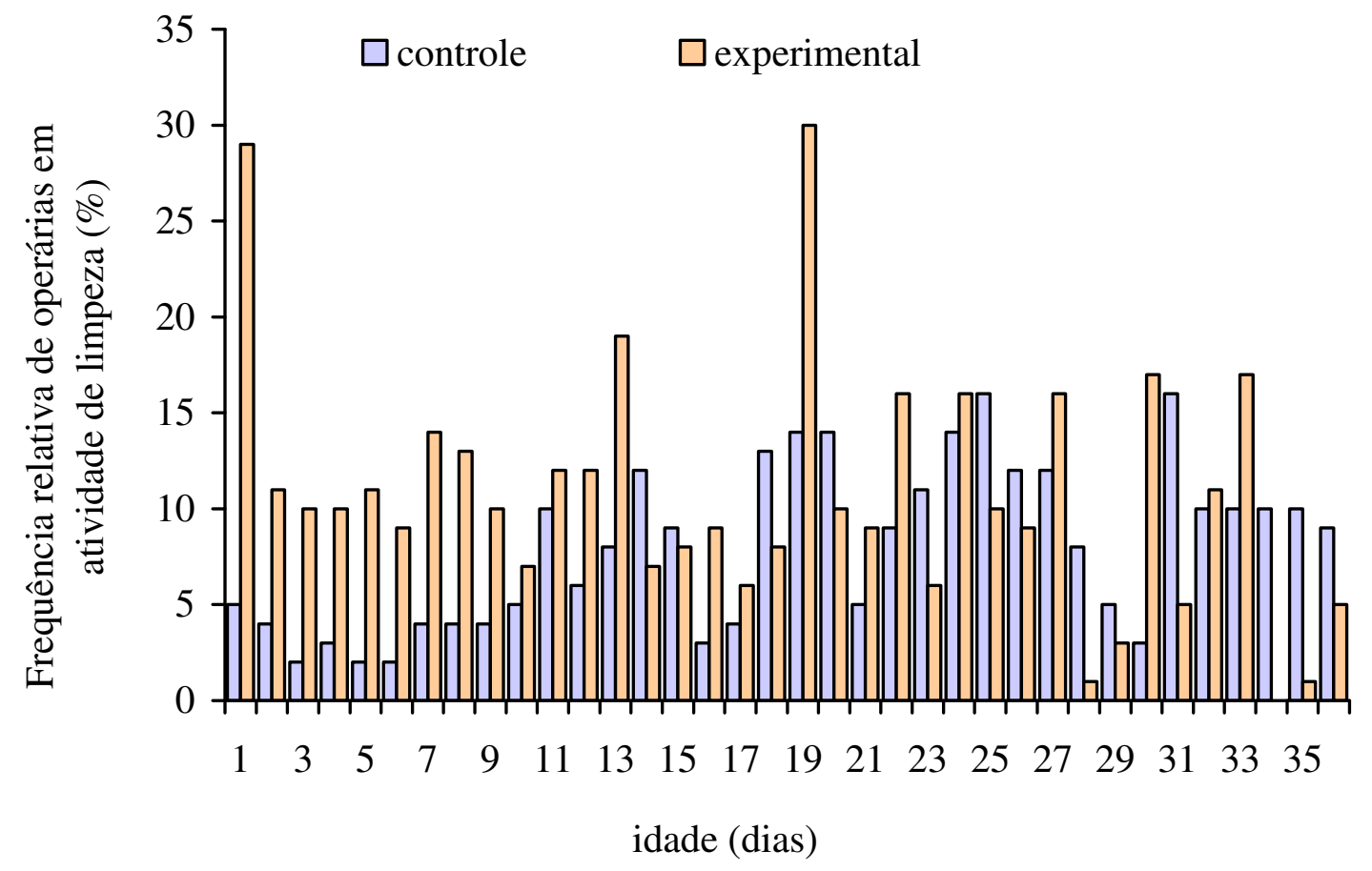

Figura 7. Frequiência relativa (\%) de abelhas africanizadas dos grupos controle e experimental que realizaram atividade de limpeza. 
Quando as tarefas referentes à atividade de limpeza foram analisadas uma a uma, observou-se que tanto as abelhas do grupo controle como as do grupo experimental fizeram autolimpeza entre 1 e 36 dias de idade, sendo que o período de maior atividade registrado para o grupo controle ocorreu em abelhas com 30 e 35 dias, com $27 \%$ e $22 \%$ de freqüência, respectivamente. No grupo experimental o período de maior intensidade na atividade de autolimpeza ocorreu nas operárias com 30 e 33 dias de idade, atingindo freqüência máxima de 15\% nas abelhas com 33 dias (Figura 8 e Tabela 1).

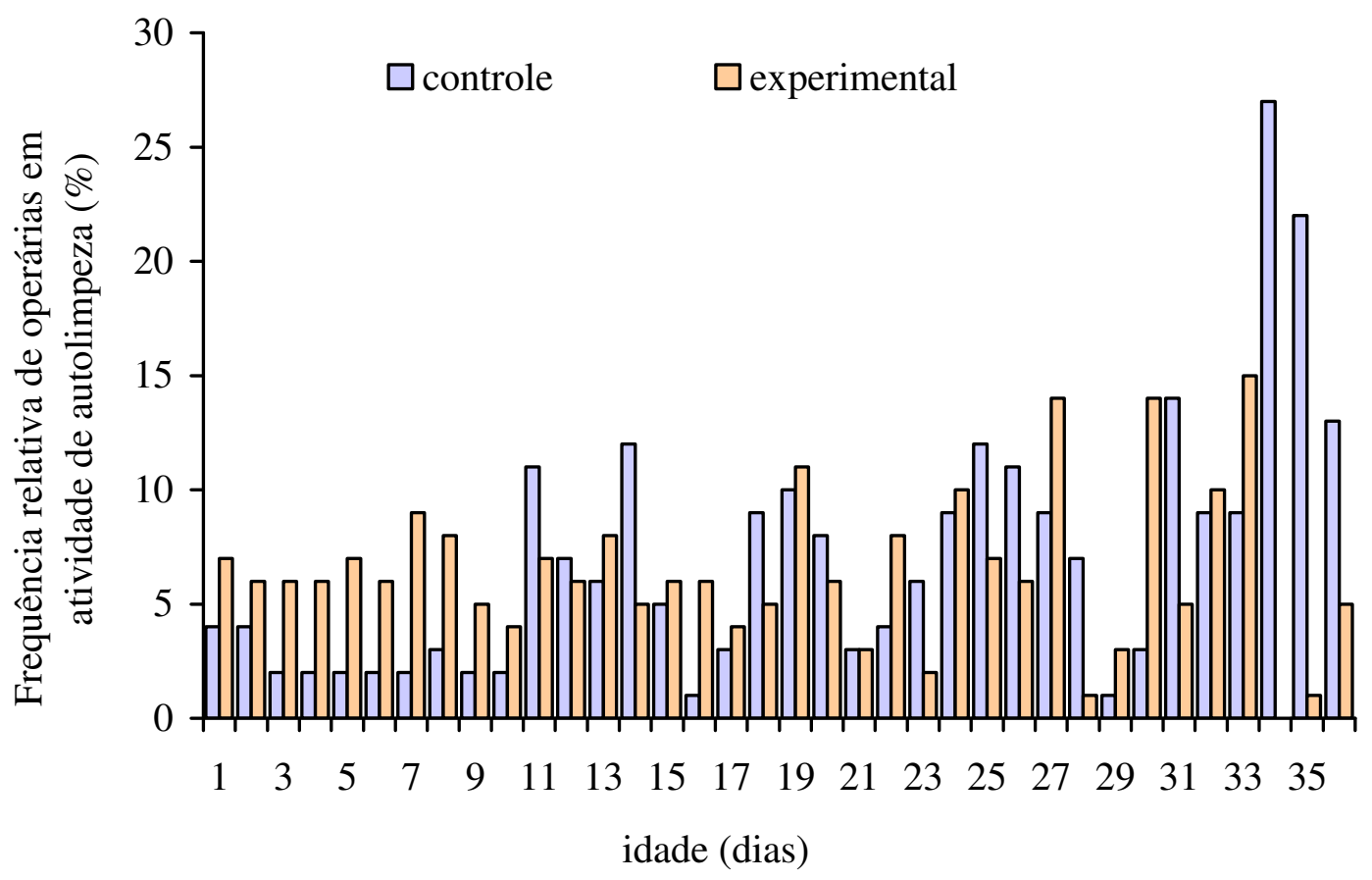

Figura 8. Frequiência relativa (\%) de abelhas africanizadas dos grupos controle e experimental que fizeram autolimpeza.

Com relação à tarefa de limpeza de células, as abelhas do grupo controle apresentaram uma atividade maior do que a observada no grupo experimental. A limpeza de células desenvolvida pelas operárias atingiu um percentual máximo de $6 \%$ no grupo experimental, em abelhas com um dia de vida. No grupo controle registrou-se uma atividade máxima de 3\%, em operárias com 20 dias de idade. As abelhas do grupo controle realizaram esta tarefa entre 4 e 25 dias de idade, enquanto as do grupo experimental a fizeram entre 1 e 26 dias (Figura 9 e Tabela 1).

O período de solicitação de limpeza registrado para as operárias do grupo controle foi menor do que o observado nas abelhas do grupo experimental. No primeiro grupo a frequiência máxima de operárias que solicitaram limpeza corporal foi de 4\%, aos 12 dias de 
vida. No segundo, foram observados dois picos de atividade, sendo que a frequência máxima registrada para este comportamento ocorreu nas operárias com 33 dias de idade, com $15 \%$ das abelhas realizando esta função. Entre o $3^{\circ}$ e o $9^{\circ}$ dias foi registrada uma oscilação de frequência entre 3 e $5 \%$, enquanto que no grupo controle apenas $1 \%$ das abelhas solicitaram limpeza corporal entre o $5^{\circ}$ e o $7^{\circ}$ dias (Figura 10 e Tabela 1).

No grupo controle a limpeza de operárias iniciou-se aos 5 dias de idade e estendeu-se até o $33^{\circ}$ dia de vida, com picos de atividade no $18^{\circ}$ e $20^{\circ}$ dias, com freqüências de $4 \%$ e $3 \%$, respectivamente. As abelhas pertencentes ao grupo experimental realizaram esta tarefa do $4^{\circ}$ ao $27^{\circ}$ dia de idade, com picos de atividade no $13^{\circ}$ e $19^{\circ}$ dias, com freqüências de $7 \%$ e $12 \%$, respectivamente (Figura 11 e Tabela 1 ).

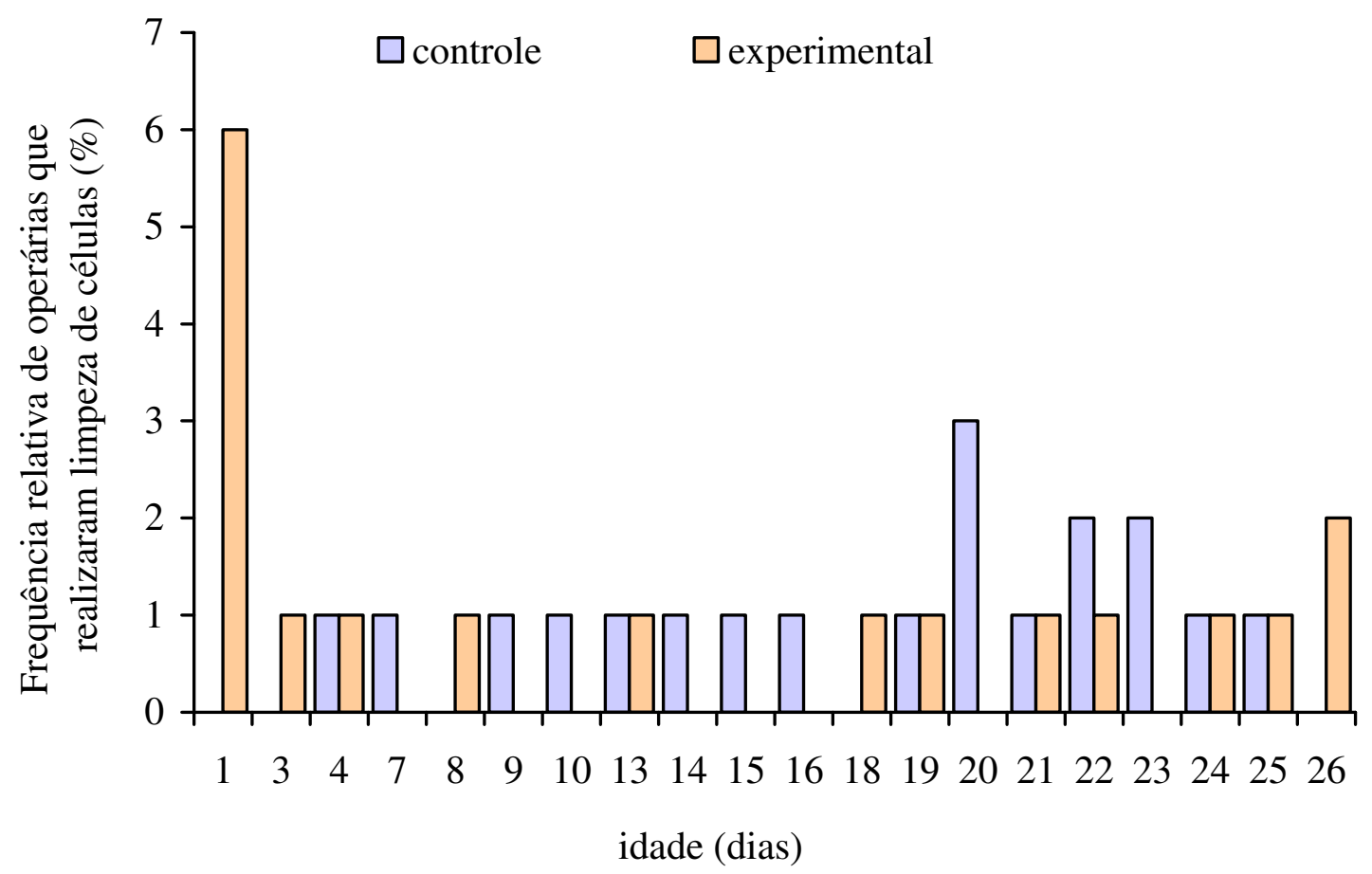

Figura 9. Frequiência relativa (\%) de abelhas africanizadas dos grupos controle e experimental que realizaram limpeza de células. 


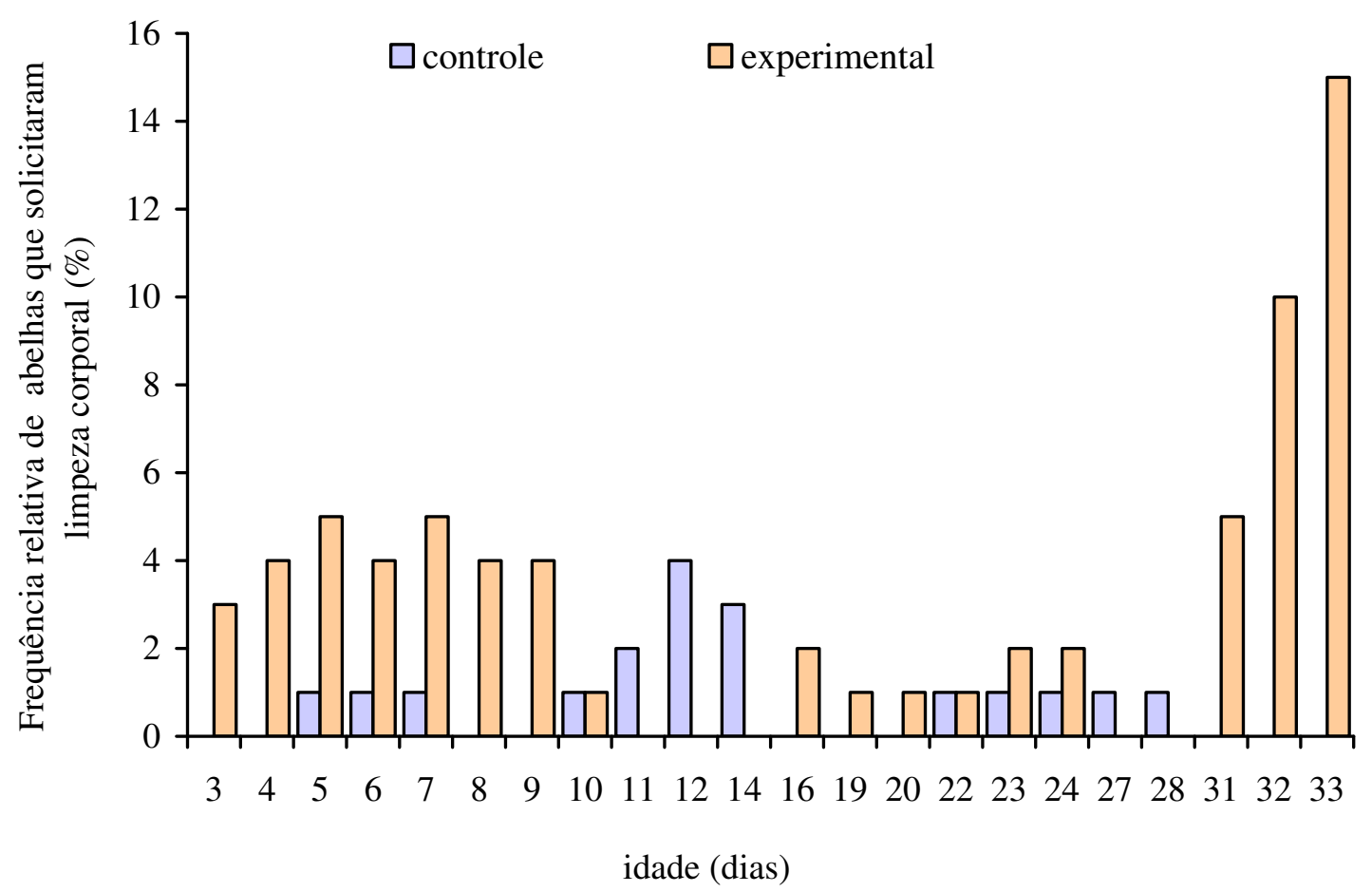

Figura 10. Frequiência relativa (\%) de abelhas africanizadas dos grupos controle e experimental que solicitaram limpeza corporal.

O período em que as operárias do grupo controle foram limpas por outras abelhas iniciou-se aos 10 dias de vida e encerrou-se no $36^{\circ}$ dia. No grupo experimental esta atividade ocorreu em operárias com idade entre 1 e 12 dias. As abelhas do grupo controle apresentaram picos de atividade entre 34 e 36 dias de vida, com uma variação de 4\% a 6\% de operárias sendo limpas neste período. No grupo experimental as abelhas não apresentaram variação na freqüência em que esta tarefa foi realizada. A frequência máxima de operárias que foram limpas por outras abelhas foi de 1\% (Figura 12 e Tabela 1).

No presente trabalho as operárias do grupo controle e do grupo experimental realizaram a atividade de limpeza entre 1 e 36 dias de vida. No entanto, no grupo controle, registrou-se um aumento dessa função a partir do $7^{\circ}$ dia e um processo de redução no $25^{\circ}$ dia, enquanto que no grupo experimental ocorreram dois picos de atividade: no $14^{\circ}$ e $19^{\circ}$ dias. Além disso, as abelhas deste grupo trabalharam intensamente na atividade de limpeza desde o primeiro dia de vida. Estes resultados diferem dos dados obtidos por Free (1980), que observou uma redução na atividade de limpeza, à medida que a idade das abelhas aumentou, mas não desapareceu totalmente. 


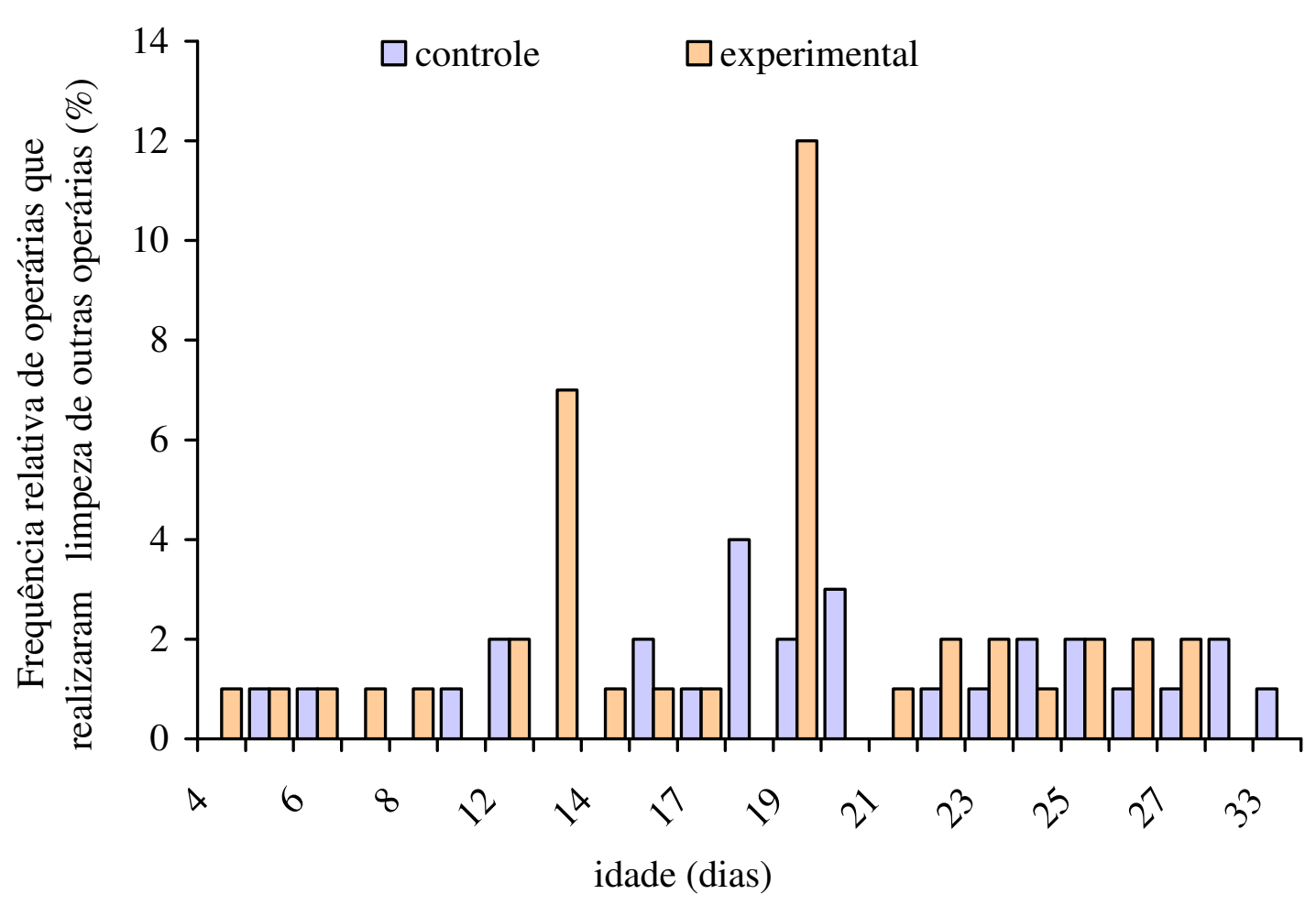

Figura 11. Freqüência relativa $(\%)$ de abelhas africanizadas dos grupos controle e experimental que realizaram limpeza de outras operárias.

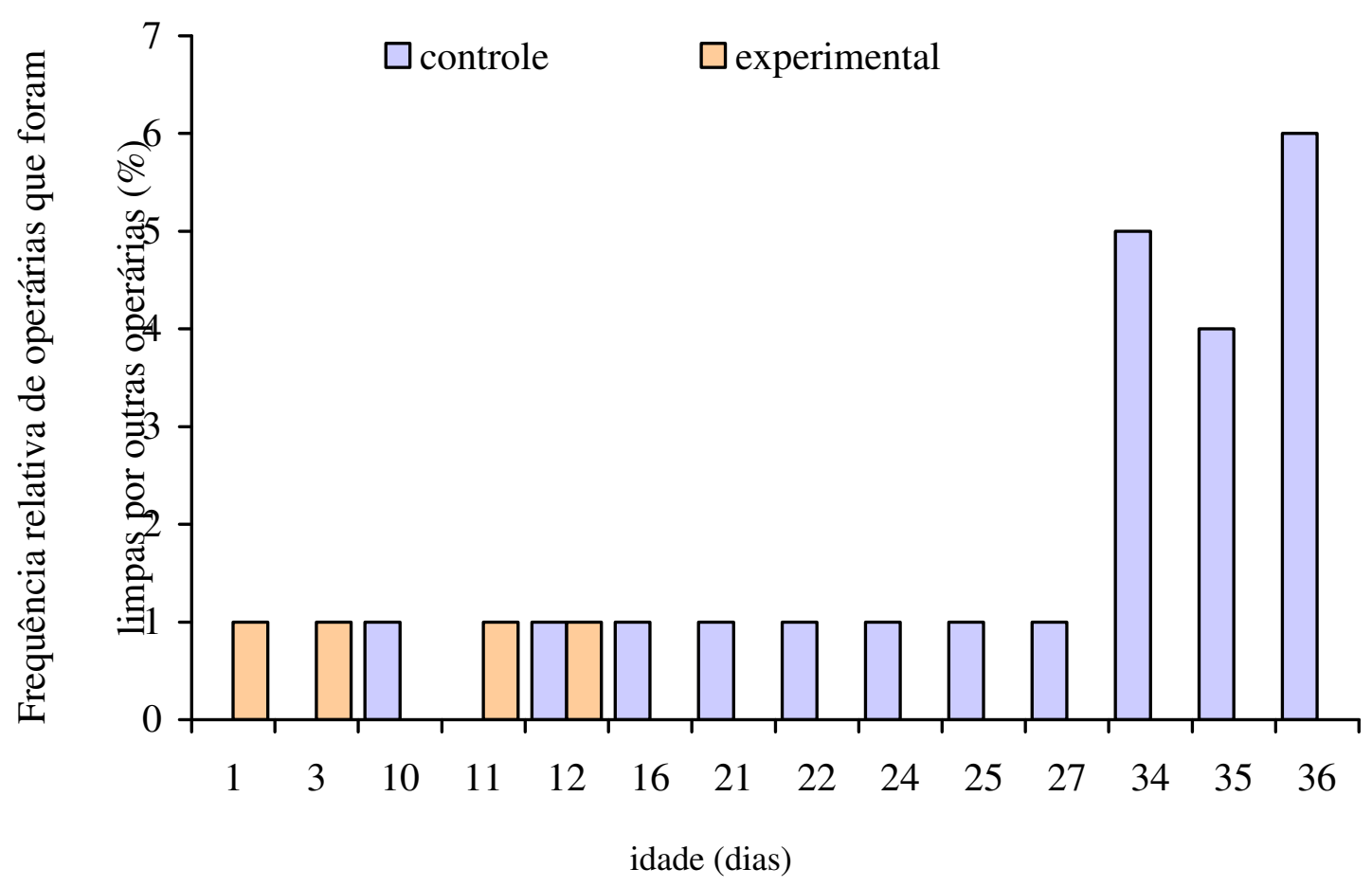

Figura 12. Frequiência relativa (\%) de abelhas africanizadas dos grupos controle e experimental que foram limpas por outras operárias. 
As tarefas referentes à atividade de limpeza que originaram diferenças significativas entre os dois grupos de abelhas foram a autolimpeza e a limpeza de células. Os resultados obtidos nas análises revelaram que as abelhas do grupo experimental foram mais eficientes em relação às do grupo controle na execução dessas duas tarefas. A tarefa que foi desenvolvida com maior freqüência pelas operárias do grupo experimental foi a autolimpeza. É provável que a diferença significativa registrada entre os dois grupos de abelhas tenha ocorrido porque as operárias alimentadas com dieta enriquecida com cafeína e apresentaram crise de abstinência e, por este motivo, estavam constantemente se limpando.

Os dados obtidos na pesquisa também revelaram que as operárias do grupo controle trabalharam com maior freqüência na limpeza de células do que as abelhas do grupo experimental. Os resultados referentes aos dois grupos são mais semelhantes aos dados obtidos por Pereira (2002), que observou operárias de abelhas africanizadas realizando limpeza de células entre 1 e 31 dias de idade. Contudo, o mencionado autor destacou que o período de maior atividade ocorreu entre 1 e 2 dias, resultado próximo ao registrado para as operárias do grupo experimental, utilizado na presente pesquisa, mas diferente do observado no grupo controle. Os resultados obtidos em relação ao período de maior atividade das operárias do grupo experimental também são similares aos encontrados por Sakagami (1953).

Vários autores registraram períodos de atividade de limpeza de células menos extensos do que os encontrados nesta pesquisa. Perepelova (1928 in MORITZ e SOUTHWICK, 1992) e Rösch (1925, 1930), citado por Ribbands (1953), observaram que esta tarefa foi realizada por operárias com 2 a 20 dias e 10 a 23 dias de idade, respectivamente. Ribbands (1953) registrou um período de atividade em abelhas de 1 a 22 dias e Sakagami (1953) observou esta função em operárias com idade entre 1 e 12 dias.

Tanto as abelhas do grupo controle como as do grupo experimental apresentaram períodos de atividade semelhantes, porém com picos de frequência diferentes. As operárias pertencentes ao primeiro grupo trabalharam mais intensamente na limpeza de células em relação às do grupo experimental. $\mathrm{O}$ período em que as abelhas foram mais ativas também foi diferente nos dois grupos analisados. A frequência de operárias do grupo experimental que executaram essa tarefa foi muito maior no primeiro dia de vida, enquanto que as abelhas do grupo controle apresentaram picos de atividade aos 20, 22 e 23 dias de idade. Esta intensa atividade de limpeza observada no grupo experimental, nos primeiros dias, pode ter ocorrido porque o organismo das operárias não estava acostumado com a presença da cafeína na dieta alimentar e, após este período, ocorreu uma adaptação à metilxantina. 


\section{Atividade de Inspeção}

O comportamento de inspeção representou 22\% (10.970 observações) das tarefas realizadas no grupo controle e 4\% (1.082 observações) das atividades registradas no grupo experimental. As abelhas apresentaram um período de atividade entre 1 e 34 dias de idade no grupo controle e de 1 a 33 dias no grupo experimental, embora o mencionado comportamento não tenha ocorrido de forma contínua neste último grupo (Tabela 1).

O comportamento de inspeção foi mais freqüente no grupo controle do que no grupo experimental. Os resultados registrados nesta pesquisa estão mais próximos dos obtidos por Pereira (2002), no que se refere ao período de execução dessa tarefa. O referido autor observou que esta atividade foi realizada por operárias de abelhas africanizadas e italianas com idade entre 1 e 29 dias e 1 e 30 dias, respectivamente. Contudo, são menos parecidos com os dados relatados por Ribbands (1953), que registrou atividade de inspeção sendo realizada por operárias de abelhas italianas entre o $1^{\circ}$ e o $24^{\circ}$ dias de idade.

Em relação ao período de maior atividade das abelhas na mencionada função, os resultados registrados para os grupos controle experimental são diferentes dos obtidos por Ribbands (1953), que observou um pico de atividade máxima para as abelhas com 1 dia de idade (50\% das abelhas inspecionando) e um segundo pico de atividade para operárias com 13-15 dias de vida. Além disso, o mesmo autor observou grande variação na frequência de operárias realizando a referida tarefa nas demais faixas etárias. Os resultados da presente pesquisa também diferem dos dados compilados por Pereira (2002) que observou maior atividade das operárias de abelhas africanizadas com 15-18 dias de vida.

No grupo experimental ocorreram dois picos para a atividade de inspeção: o primeiro entre 1 e 9 dias de idade e o segundo entre o $17^{\circ}$ e o $22^{\circ}$ dias, com variação de 34 a $54 \%$ e de 15 a 36\%, respectivamente (Figura 13 e Tabela 1). Para as abelhas do grupo controle não foi observado nenhum período nítido no qual a atividade de inspeção tenha sido realizada com maior intensidade, ou seja, foram registradas várias oscilações na frequência de execução de referida tarefa, ao longo da vida das operárias. Este resultado é muito semelhante ao que foi obtido por Pereira (2002) para operárias de abelhas italianas (A. m. ligustica).

Uma análise estatística comparativa dos resultados obtidos para os dois grupos de abelhas estudados indicou diferença significativa $(U=155,46 ; p<0,0001)$, em relação à citada tarefa. 


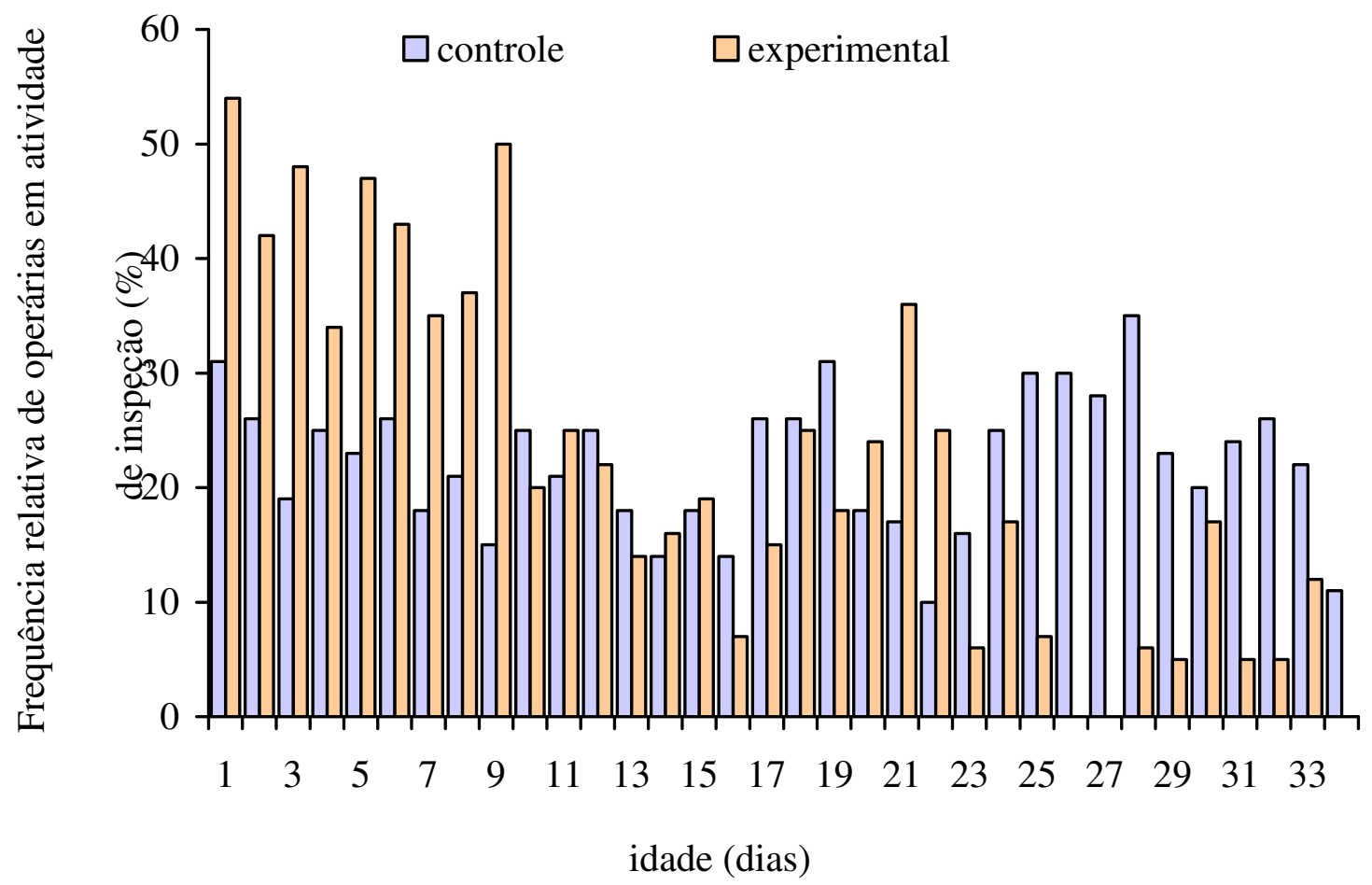

Figura 13. Frequiência relativa (\%) de abelhas africanizadas dos grupos controle e experimental que realizaram atividade de inspeção.

Estudos realizados com roedores revelaram que o estímulo locomotor fornecido pela cafeína depende da dose administrada (DALY et al., 1981; SNYDER et al., 1981). A indução da atividade locomotora pela cafeína resulta em uma relação bifásica de dose-resposta, sendo que em doses baixas $(5-10 \mathrm{mg} / \mathrm{kg})$ ocorre apenas uma estimulação, com a introdução de 10 $50 \mathrm{mg} / \mathrm{kg}$ acontece uma grande atividade e com doses acima de 50mg/kg a cafeína causa depressão (TITHAPANHA et al., 1972; HOLTZMAN e FINN, 1988). Embora existam poucos estudos sobre a fisiologia de insetos sob a ação da cafeína, é possível que o estímulo que as abelhas do grupo experimental receberam, ao consumir o cândi cafeinado, tenha aumentado seu estado de excitação e prejudicado a atividade de inspeção deste grupo. Nas observações de comportamento realizadas com as operárias do grupo controle verificou-se que a atividade de inspeção foi executada com tranqüilidade, enquanto as operárias do grupo experimental sempre desenvolveram esta tarefa com grande agitação.

\section{Atividade de Termorregulação}

O trabalho de termorregulação da colônia correspondeu a 32\% (16.332 observações) das atividades realizadas pelas abelhas do grupo controle e $26 \%$ (7.032 observações) das 
tarefas desenvolvidas pelas operárias do grupo experimental. No geral, as abelhas que receberam dieta contendo cafeína foram menos freqüentes do que as abelhas alimentadas com dieta normal, na execução desta função. As abelhas do primeiro grupo realizaram esta tarefa entre 1 e 35 dias de idade, enquanto as do segundo grupo a fizeram entre 1 e 31 dias. $\mathrm{O}$ período de maior intensidade no desempenho da referida tarefa ocorreu entre 1 e 10 dias de idade nos dois grupos, sendo que a frequência de operárias que trabalharam nessa atividade variou 23 a $73 \%$ no grupo controle e de 15 a 47\% no grupo experimental. Uma comparação dos resultados obtidos na pesquisa indicou que o número de operárias do grupo controle que realizaram termorregulação foi menor em relação ao observado para as abelhas do grupo experimental $(\mathrm{U}=122,25 ; \mathrm{p}<0,0001)$ (Figura 14 e Tabela 1). De acordo com Lindauer (1961), o aquecimento do ninho realizado pelas operárias de Apis mellifera é resultante das atividades musculares e Roth (1965) afirmou que a produção de calor ocorre por vibração dos músculos torácicos de vôo.

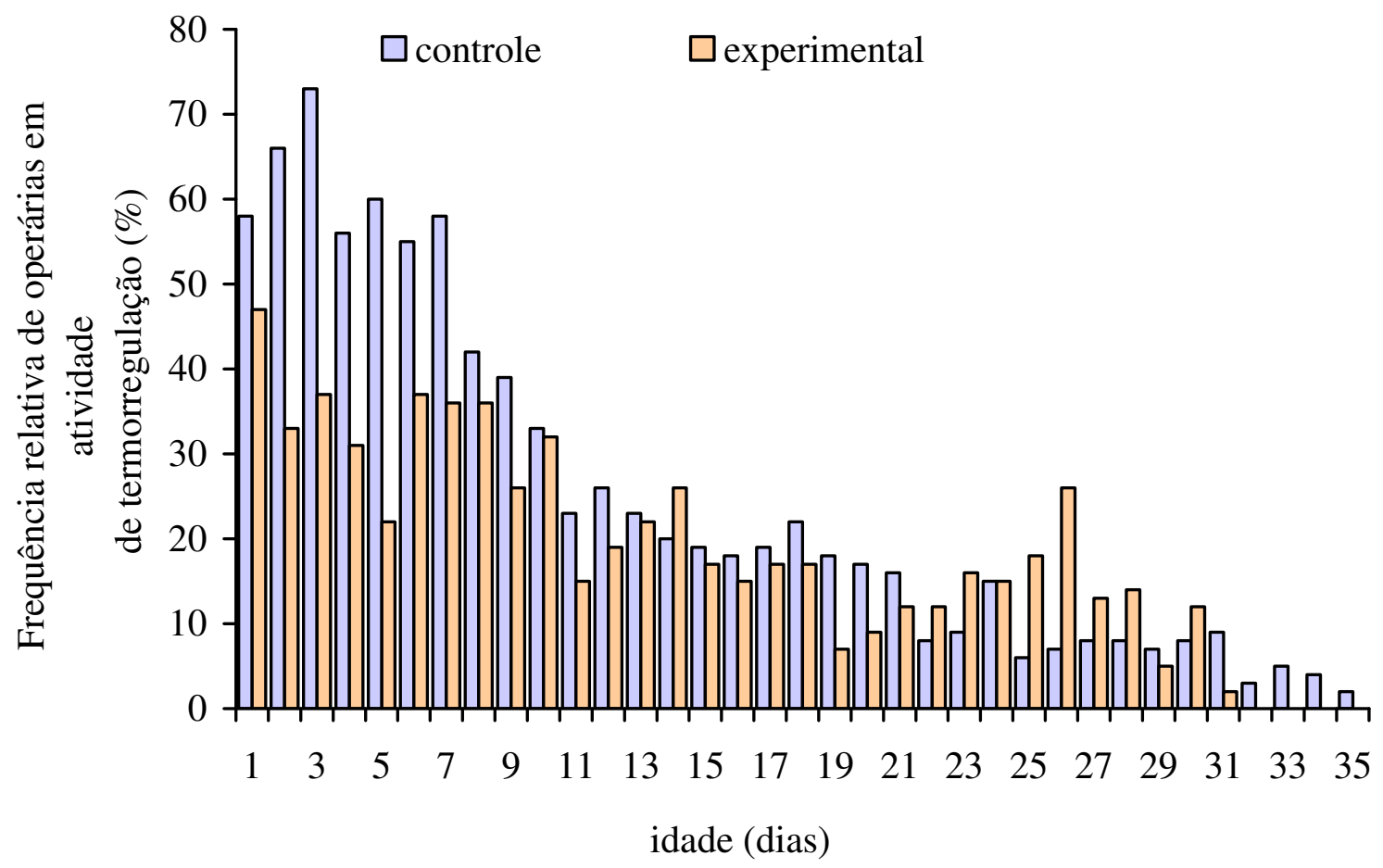

Figura 14. Frequiência relativa (\%) de abelhas africanizadas dos grupos controle e experimental que realizaram atividade de termorregulação.

Estudos realizados com seres humanos sugerem que a cafeína causa aumento na disponibilidade de ácidos graxos livres para o músculo, resultando em um aumento da taxa de oxidação de lipídios. Dessa forma, com a utilização antecipada de lipídios para a produção de 
energia, o glicogênio muscular pode ser poupado, retardando a fadiga. Como o glicogênio muscular é a primeira limitação nos exercícios de longa duração, a cafeína pode exercer efeitos ergogênicos nos exercícios onde o glicogênio é o fator limitante do desempenho (IVY, 1979; ESSING et al., 1980).

A musculatura utilizada no vôo dos insetos é formada por músculos estriados que, em muitos aspectos, são semelhantes aos músculos esqueléticos existentes nos vertebrados, principalmente no que se refere aos tipos de componentes estruturais, diferindo apenas no arranjo e disposição desses elementos, bem como no caminho pelo qual a tensão é transmitida para o exoesqueleto, nos insetos (SMYTH, 1985).

Portanto, embora ainda não existam estudos específicos sobre a ação da cafeína na musculatura de insetos, é provável que esta substância tenha atuado na musculatura das operárias do grupo experimental, tendo provocado o adiamento da fadiga nos indivíduos que realizaram a atividade de termorregulação e fazendo com que o número de abelhas necessário para manter a temperatura interna do ninho fosse menor em relação ao que foi observado no grupo controle.

\section{Atividade de Construção}

No presente trabalho a construção de favos correspondeu a 5\% (2.522 observações) das atividades desenvolvidas pelas operárias do grupo controle e 3\% (811 observações) das tarefas registradas para as abelhas do grupo experimental. As abelhas do grupo alimentado com dieta contendo cafeína iniciaram a atividade de construção no primeiro dia de vida, mas nessa idade apenas $1 \%$ das operárias realizaram essa tarefa. As abelhas desse grupo executaram esta função até o $33^{\circ}$ dia de vida, sendo que o pico máximo de atividade das operárias (14\%) foi registrado nessa idade. De $2 \%$ a $15 \%$ das abelhas do grupo controle ocuparam-se desta tarefa entre o $4^{\circ}$ e o $29^{\circ}$ dias de vida, sendo registrados picos de trabalho aos 17, 23 e 24 dias de idade, com 15\%, 12\% e 10\% das operárias realizando atividade de construção, respectivamente (Figura 15 e Tabela 1). 


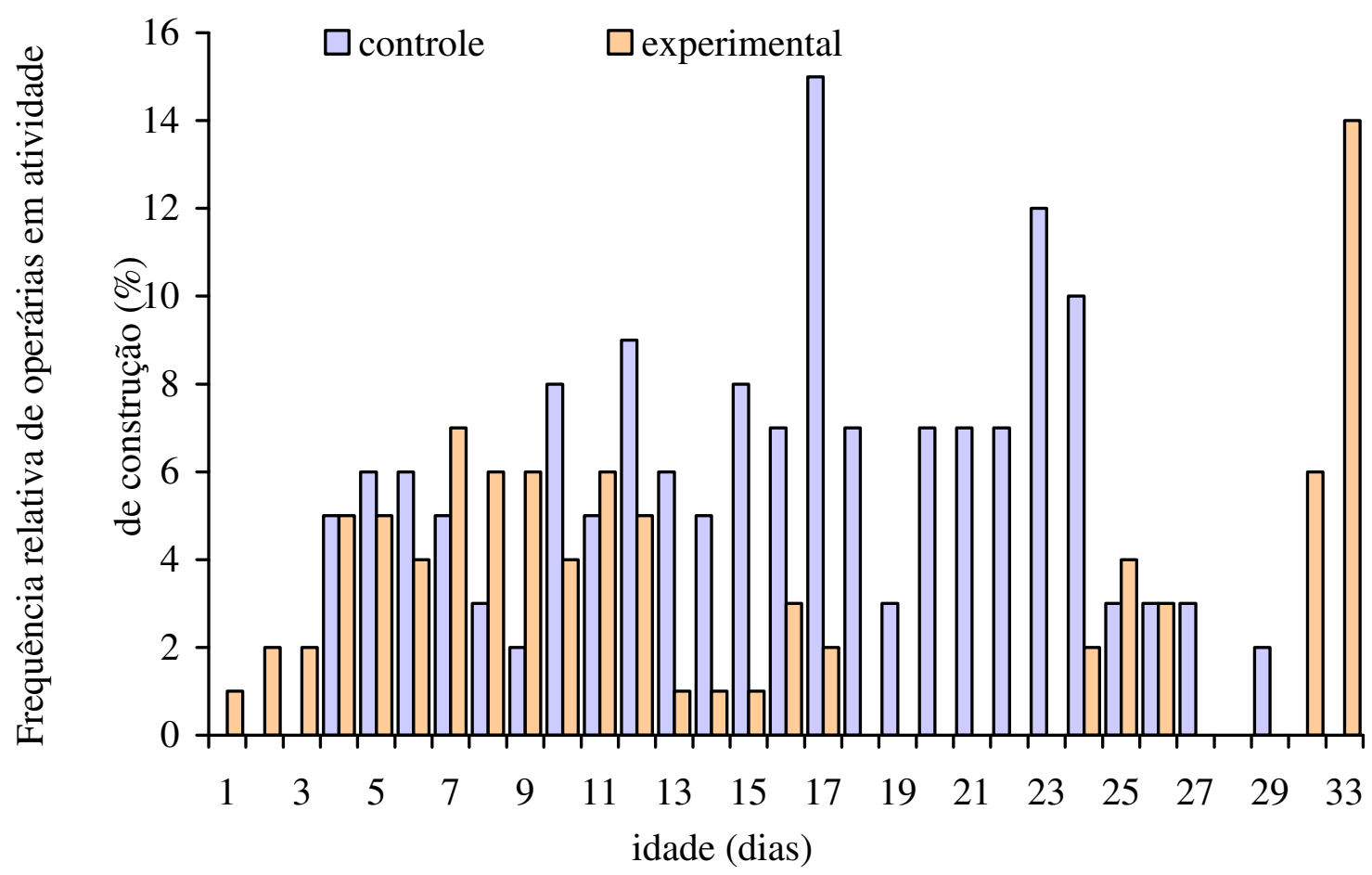

Figura 15. Freqüência relativa (\%) de abelhas africanizadas dos grupos controle e experimental que realizaram atividade de construção de favo.

Ribbands (1953) observou que operárias de Apis mellifera apresentaram um período de atividade entre 7 e 21 dias de idade, com picos de trabalho entre 8 e 9 dias, enquanto Rösch (1930) registrou uma amplitude de variação bem maior (entre 2 a 52 dias de vida) para a mesma tarefa, com um pico de atividade aos 16 dias de idade. Os dados relatados por estes autores são muito diferentes em relação aos obtidos nesta pesquisa, tanto no que se refere ao período em que as abelhas trabalharam na construção de favos, como na fase em que a tarefa foi executada com maior intensidade. O resultado mais discrepante ocorreu no grupo experimental. As operárias tratadas com dieta contendo cafeína apresentaram um pico de atividade significativo no $33^{\circ}$ dia de vida, enquanto as abelhas que receberam dieta normal trabalharam mais intensamente no $17^{\circ}$ dia de idade.

Em relação ao grupo controle, os resultados obtidos nesta pesquisa apresentam maior semelhança com os dados compilados por Pereira (2002), que registrou um período de atividade entre 6 e 31 dias de idade para as operárias de abelhas africanizadas. Para as abelhas italianas o referido autor observou que a mesma tarefa foi realizada do $7^{\circ}$ ao $22^{\circ}$ dias de vida.

No que se refere à construção de novas células no favo de crias observou-se que as operárias do grupo experimental trabalharam muito mais em relação às operárias do grupo 
controle, pois construíram um número de células (401) quase duas vezes maior do que o referido grupo (208 células), embora o número de operárias que realizaram esta função tenha sido menor no primeiro grupo. A comparação dos dados referentes ao número de células novas construídas pelas operárias dos dois grupos indicou uma diferença significativa $(\mathrm{U}=$ 572,00; $\mathrm{p}=0,0282$ ) (Tabela 1). Portanto, a cafeína estimulou as glândulas de cera a produzirem mais e, assim, as abelhas do grupo experimental a trabalharem mais intensamente na construção de novas células, o que resultou em um aumento de $48 \%$ na área de favo construída.

Ishay e Paniry (1979) estudaram os efeitos da cafeína em vespas e verificaram que as operárias alimentadas com dieta contendo esta substância construíram células rudimentares, com região basal inacabada. Além disso, os referidos autores observaram que essas estruturas eram menores em relação às células rudimentares construídas pelas vespas do grupo controle, que não receberam cafeína na dieta. Contudo, não souberam explicar as causas da modificação na extensão da elaboração das células do favo, nem a interrupção observada nesta atividade, no início da construção. Em uma pesquisa realizada com aranhas, Witt (1956) observou que a cafeína produziu alterações significativas no comportamento de Nephila sp, fazendo com que ela construísse uma teia de menores dimensões.

Em seres humanos algumas pesquisas indicam que uma das principais propriedades da cafeína é estimular o Sistema Nervoso Central (SNC), aumentando o estado de vigília, reduzindo a fadiga e diminuindo o tempo de reação de algumas tarefas (GREDEN, 1974). Além disso, ela é capaz de aumentar a excitabilidade reflexa (RITCHIE, 1975).

\section{Atividade de Recepção de Alimento}

A atividade de recepção de alimento representou 2\% (996 observações) das tarefas desenvolvidas pelas abelhas do grupo controle e 5\% (1.352 observações) das funções registradas para as operárias do grupo experimental. As abelhas do grupo controle realizaram esta atividade entre 6 e 33 dias de idade, com picos de trabalho (7\% das abelhas em cada caso considerado) no $18^{\circ}$ e $32^{\circ}$ dias. As operárias do grupo experimental fizeram recepção de alimento entre o $1^{\circ}$ e o $32^{\circ}$ dias de vida, sendo que essa tarefa foi realizada com maior freqüência no $20^{\circ}$ dia (12\% das abelhas) (Figura 16 e Tabela 1). Apesar de as abelhas do grupo experimental aparentemente terem executado esta tarefa um maior número de vezes, a análise comparativa dos dados indicou diferença não significativa entre os dois grupos estudados $(\mathrm{U}=179,08 ; \mathrm{p}=0,4562)$. 


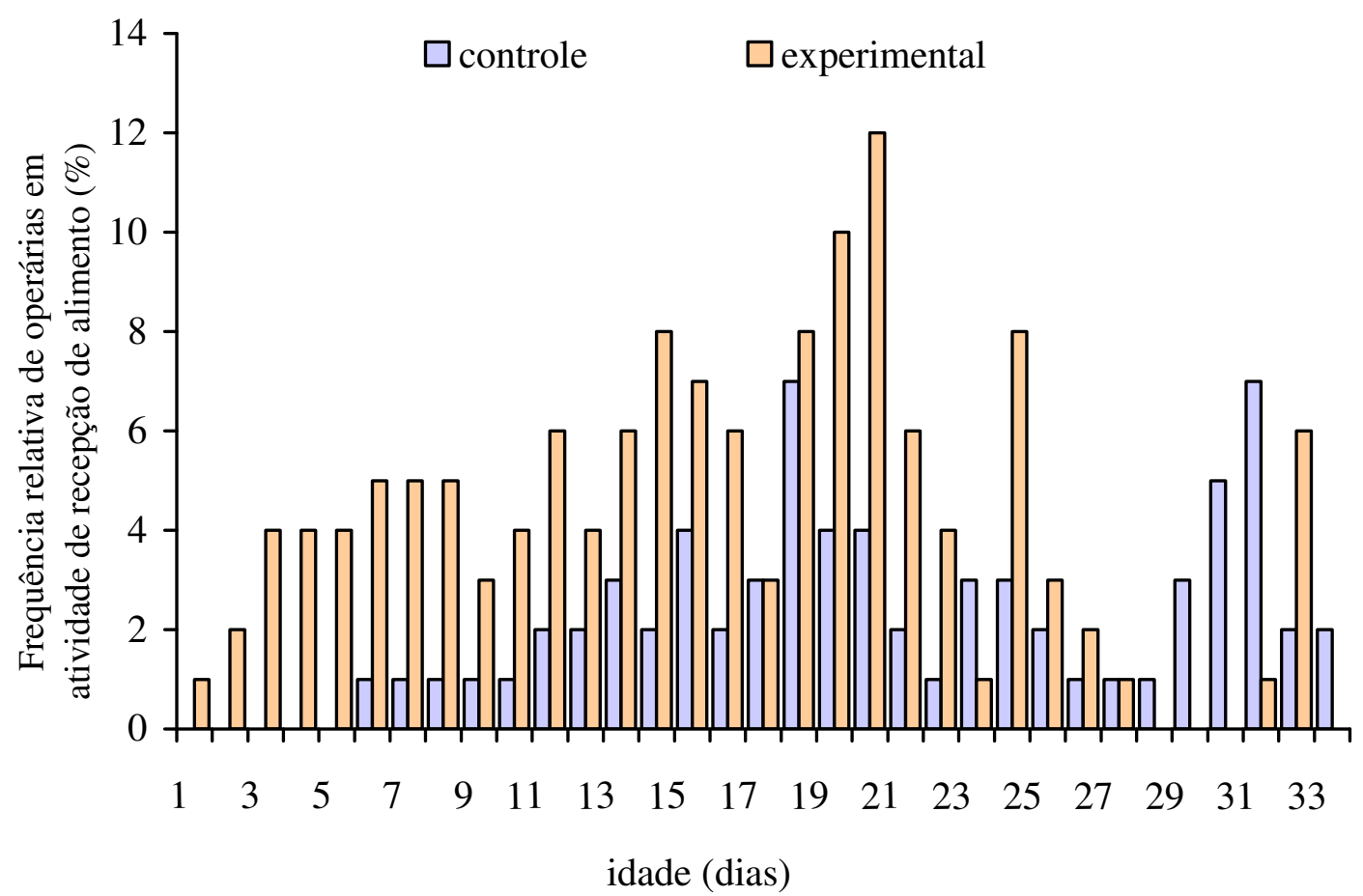

Figura 16. Freqüência relativa $(\%)$ de abelhas africanizadas dos grupos controle e experimental que realizaram atividade de recepção de alimento.

O período de atividade registrado para as operárias do grupo controle foi muito parecido com o obtido por Sakagami (1953), que observou recepção de alimento por abelhas com idade entre 5 e 30 dias. O pico de atividade máxima (20 dias) observado para as operárias do grupo experimental foi muito próximo do valor encontrado por Pereira (2002), que registrou um maior número de abelhas africanizadas realizando a referida função no $21^{\circ}$ dia de idade. No caso das operárias do grupo controle os dois picos de maior atividade, registrados no $18^{\circ}$ e $32^{\circ}$ dias, foram muito diferentes no que se refere aos resultados obtidos por Pereira (2002) e dois outros autores: Sakagami (1953) relatou um período de atividade para abelhas com idade entre 5 e 30 dias e observou um maior número de operárias executando essa função no $12^{\circ}$ dia. Rösch (1925, 1930 in RIBBANDS, 1953) registrou atividade entre 8 e 14 dias, com um pico de trabalho no $11^{\circ}$ dia de vida.

\section{Atividade de Defesa da Colônia}

Esta atividade correspondeu a 7\% de todas as tarefas realizadas pelas abelhas dos dois grupos estudados, embora tenham sido realizadas 3.530 observações no grupo controle e 1.893 no grupo experimental.. No grupo experimental observou-se um período de atividade de 
defesa entre o $1^{\circ}$ e o $28^{\circ}$ dias de vida. No grupo controle esta tarefa foi realizada por operárias com idade entre 1 e 34 dias. Na Figura 17 pode-se observar que os resultados obtidos para o grupo controle apresentaram menor variação em relação aos registrados para o grupo experimental. No primeiro grupo, a frequiência de operárias que realizaram esta função variou de 2 a 12\%, enquanto no segundo foi registrada uma variação de 2 a 21\%. Os picos máximos de atividade observados para as operárias dos grupos controle e experimental ocorreram no $9^{\circ}$ e $12^{\circ}$ dias de idade, respectivamente (Figura 17 e Tabela 1). Uma análise estatística comparativa entre os dados referentes ao comportamento de defesa da colônia, obtidos para os dois grupos de abelhas, indicou diferença significativa $(U=121,89 ; p<0,0001)$.

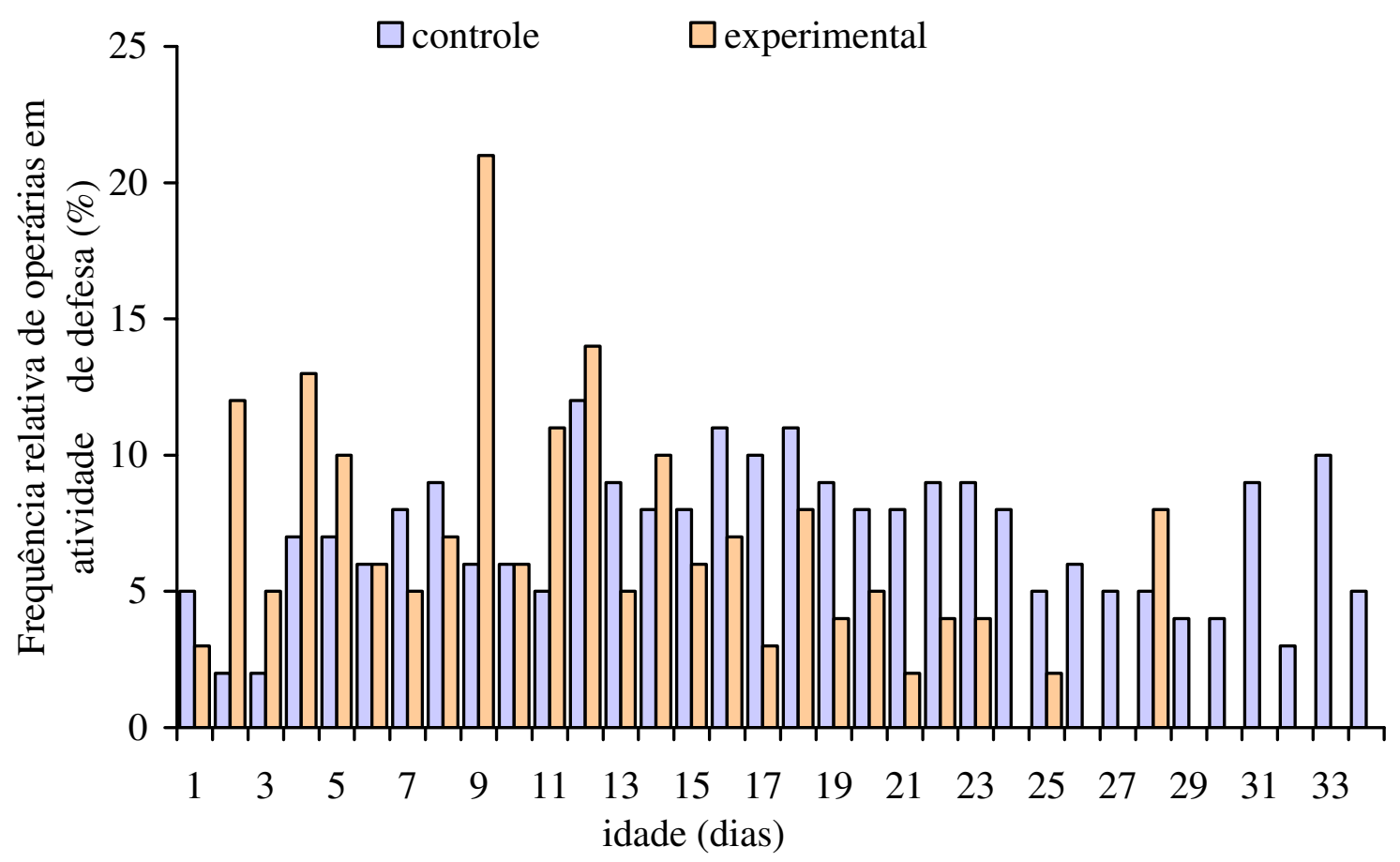

Figura 17. Freqüência relativa (\%) de abelhas africanizadas dos grupos controle e experimental que realizaram atividade de defesa da colônia.

Os resultados obtidos para as operárias do grupo experimental e do controle foram muito diferentes no que se refere ao número de abelhas que realizaram a tarefa de defesa da colônia $(\mathrm{U}=121,89 ; \mathrm{p}<0,0001)$. Os dados registrados para as abelhas do grupo controle são muito semelhantes aos compilados por Sakagami (1953), que registrou um período de atividade de defesa em operárias com idade entre 2 e 33 dias e observou que esta tarefa foi realizada com maior frequência entre o $10^{\circ}$ e o $16^{\circ}$ dias. Por outro lado, Pereira (2002) registrou dois períodos de atividade de defesa da colônia para as abelhas africanizadas, o 
primeiro entre o $14^{\circ}$ e o $18^{\circ}$ dias e o segundo, entre o $22^{\circ}$ e o $26^{\circ}$ dias, sendo que o pico de atividade máxima ocorreu no $26^{\circ}$ dia. Os dados registrados para as abelhas do grupo experimental diferem dos resultados obtidos por Ribbands (1953), Sakagami (1953) e Pereira (2002), tanto em relação ao período da vida em que as operárias defenderam a colônia, como no que se refere à faixa etária em que a mencionada tarefa foi realizada com maior frequência.

\section{Atividade de Alimentação Larval}

Ao todo, $4 \%$ das operárias do grupo controle (1.590 observações) trabalharam na alimentação de larvas, enquanto que no grupo experimental $18 \%$ das abelhas marcadas $(4.868$ observações) executaram esta tarefa. No grupo controle a referida atividade foi realizada entre 2 e 31 dias de idade, com maior frequência entre o $13^{\circ}$ e o $22^{\circ}$ dias. As abelhas pertencentes ao grupo experimental trabalharam como alimentadoras de crias entre 1 e 27 dias de idade, sendo que esta atividade foi mais freqüente entre o $4^{\circ}$ e o $17^{\circ}$ dias. Os picos máximos de atividade registrados para as abelhas do grupo controle (9\%) e do grupo experimental $(15 \%)$ ocorreram no $17^{\circ}$ e $11^{\circ}$ dias de vida, respectivamente (Figura 18 e Tabela 1). Os resultados obtidos para as abelhas dos dois grupos foram comparados, sendo obtido um valor significativo no teste estatístico utilizado $(U=149,34 ; p<0,0001)$, em relação ao número de operárias que fizeram alimentação larval.

Quando comparados com os resultados obtidos por outros autores, os dados registrados para as abelhas do grupo controle são muito diferentes. Sakagami (1953) verificou que larvas mais jovens foram alimentadas por operárias com idade entre 1 e 20 dias, enquanto as larvas mais velhas receberam alimento fornecido por abelhas de 1 a 23 dias. No primeiro caso, as operárias trabalharam mais intensamente entre o quarto e o sétimo dias de idade e, no segundo, a fase de maior frequência para a mencionada atividade ocorreu entre o $3^{\circ}$ e o $10^{\circ}$ dias. Os dados relatados por Lindauer (1952) são os que mais se aproximam dos resultados obtidos no grupo controle e também no grupo experimental. O referido autor registrou períodos de atividade entre 2 e 26 dias e de 2 a 28 dias, para operárias que realizaram alimentação de larvas com menos de quatro dias de vida e acima de quatro dias, respectivamente. As idades médias nas quais as operárias trabalharam mais intensamente na alimentação dos dois tipos de larvas foram 12,8 e 11,5 dias aproximadamente. Estes dados são muito semelhantes aos resultados obtidos para as operárias do grupo experimental. 


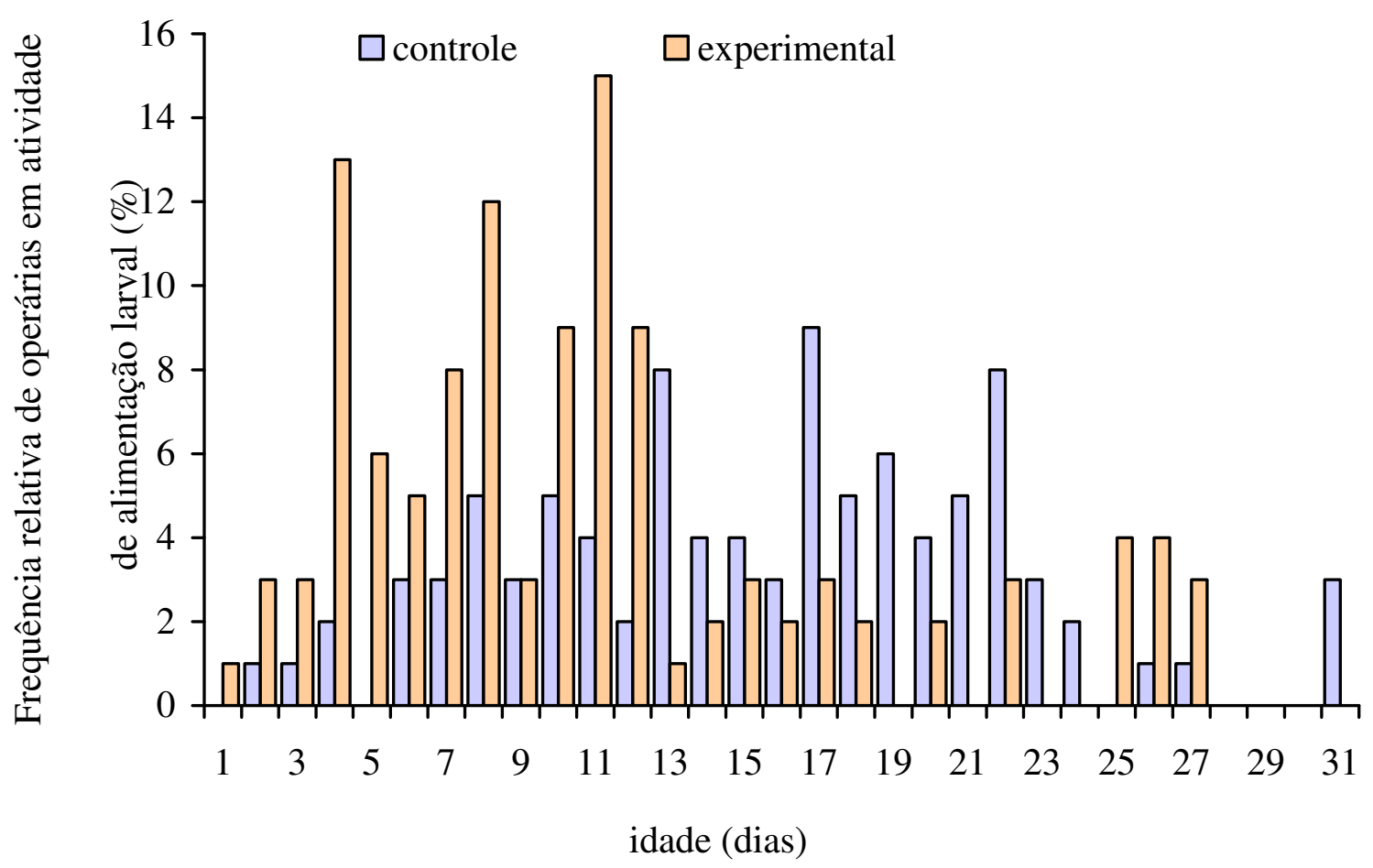

Figura 18. Freqüência relativa (\%) de abelhas africanizadas dos grupos controle e experimental que realizaram atividade de alimentação larval.

Perepelova (1928, in MORITZ e SOUTHWICK, 1992) observou que larvas com mais de 4 dias de idade foram alimentadas por operárias com 3 a 12 dias de vida, sendo que as abelhas que realizaram essa função com maior frequência tinham, em média, 5,2 dias. Por outro lado, as larvas com menos de 4 dias receberam alimento de operárias com idade entre 6 e 16 dias e essa tarefa foi realizada, com maior frequência, por abelhas com idade média de 9,2 dias. Rösch (1925, 1930 in RIBBANDS, 1953) registrou um período de alimentação de larvas com idade superior a 4 dias, por abelhas com 3 - 11 dias de idade. As operárias que alimentaram um maior número de larvas tinham, em média, 4,6 dias. O mesmo autor observou que as larvas com menos de 4 dias de idade foram alimentadas por operárias com 6 13 dias de vida. Essa atividade foi realizada com maior frequência por abelhas que tinham, em média, 8,6 dias.

\section{Atividade de coleta de recursos alimentares}

Considerando os dados referentes à coleta de recursos alimentares (néctar e pólen) realizada pelas abelhas africanizadas dos grupos controle e experimental, observou-se que $25 \%$ (6.762 observações) das operárias alimentadas com cafeína realizaram a referida tarefa, 
em relação às demais atividades. No grupo controle 21\% (10.752 observações) das operárias trabalharam como coletoras de alimento. As abelhas deste grupo realizaram esta função entre o $6^{\circ}$ e o $40^{\circ}$ dias de vida, sendo que a frequência máxima de atividade ocorreu entre o $37^{\circ}$ e o $40^{\circ}$ dias. No grupo experimental as operárias fizeram a mencionada tarefa entre o $2^{\circ}$ e o $39^{\circ}$ dias de idade e as maiores freqüências de atividade foram registradas entre o $34^{\circ}$ e o $39^{\circ}$ dias (Figura 19 e Tabela 1). Os resultados referentes à atividade de coleta de recursos pelas operárias dos dois grupos foram analisados comparativamente e o teste estatístico indicou diferença significativa $(U=160,06 ; p=0,0001)$.

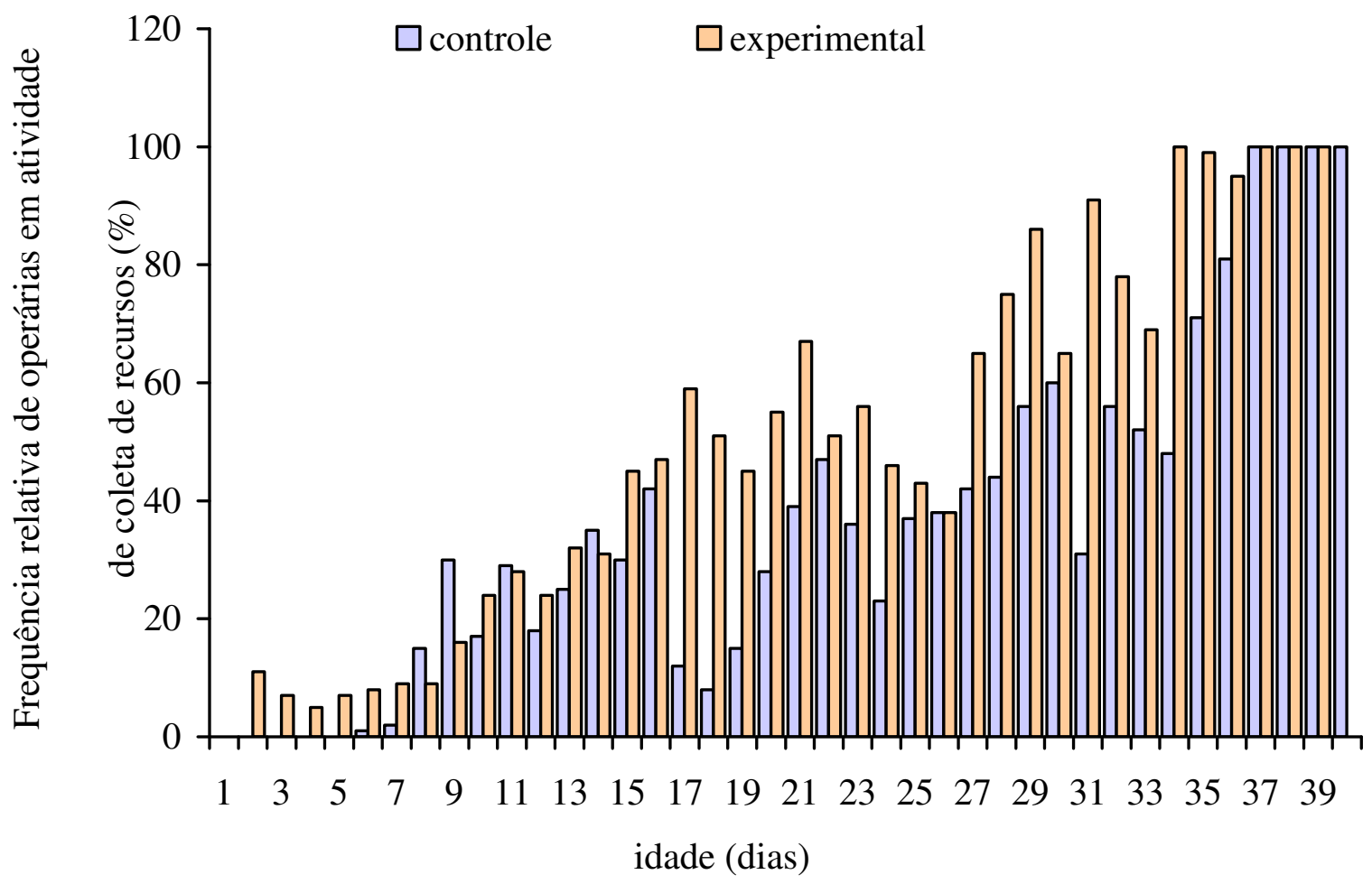

Figura 19. Freqüência relativa $(\%)$ de abelhas africanizadas dos grupos controle e experimental que coletaram recursos alimentares.

No grupo experimental $89 \%$ (6.018 observações) das operárias realizaram coleta de pólen, enquanto que no grupo controle $11 \%$ (1.183 observações) das abelhas executaram essa atividade. Neste grupo a mencionada tarefa foi realizada entre o $6^{\circ}$ e o $40^{\circ}$ dias de idade, mas de forma descontínua. O maior pico de atividade foi registrado no $35^{\circ}$ dia $(15 \%$ das operárias). As operárias do grupo experimental realizaram a referida função entre o $2^{\circ}$ e o $26^{\circ}$ dias de idade, com maior atividade no $11^{\circ}$ e $15^{\circ}$ dias, sendo que $17 \%$ das operárias coletaram pólen em ambos os dias. Uma análise comparativa dos resultados obtidos na pesquisa indicou 
diferença significativa $(U=529,50 ; p<0,005)$ entre os grupos controle e experimental, em relação à coleta de pólen (Figura 20 e Tabela 1).

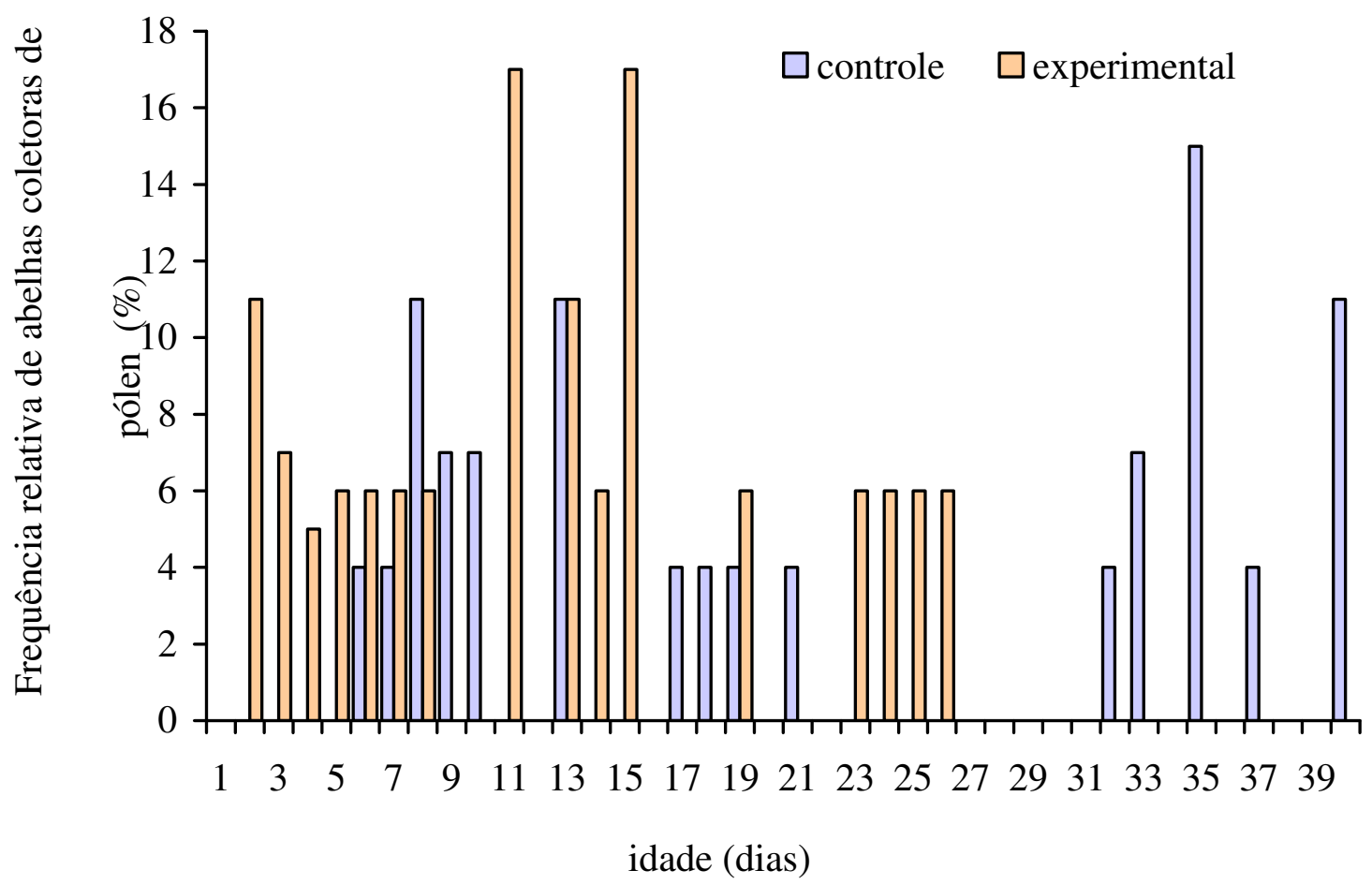

Figura 20. Freqüência relativa (\%) de operárias de abelhas africanizadas dos grupos controle e experimental que realizaram coleta de pólen.

Nos dois grupos estudados $50 \%$ das operárias coletaram néctar (5.376 observações no grupo controle e 3.381 no grupo experimental). As operárias do grupo controle realizaram essa tarefa entre o $6^{\circ}$ e o $43^{\circ}$ dias de idade, sendo que a atividade máxima das operárias (9\%) ocorreu no $35^{\circ}$ dia. No grupo experimental a mencionada tarefa foi realizada entre o $5^{\circ}$ e o $39^{\circ}$ dias de idade. O período de maior atividade das operárias ocorreu nos primeiros dias de vida, entre o $5^{\circ}$ e o $13^{\circ}$ dias, com freqüência máxima de $15 \%$ no $12^{\circ}$ dia. A análise comparativa dos dados indicou diferença significativa entre as abelhas dos dois grupos estudados, no que se refere à coleta de néctar $(\mathrm{U}=578,50 ; \mathrm{p}<0,005)$ (Figura 21 e Tabela 1). 


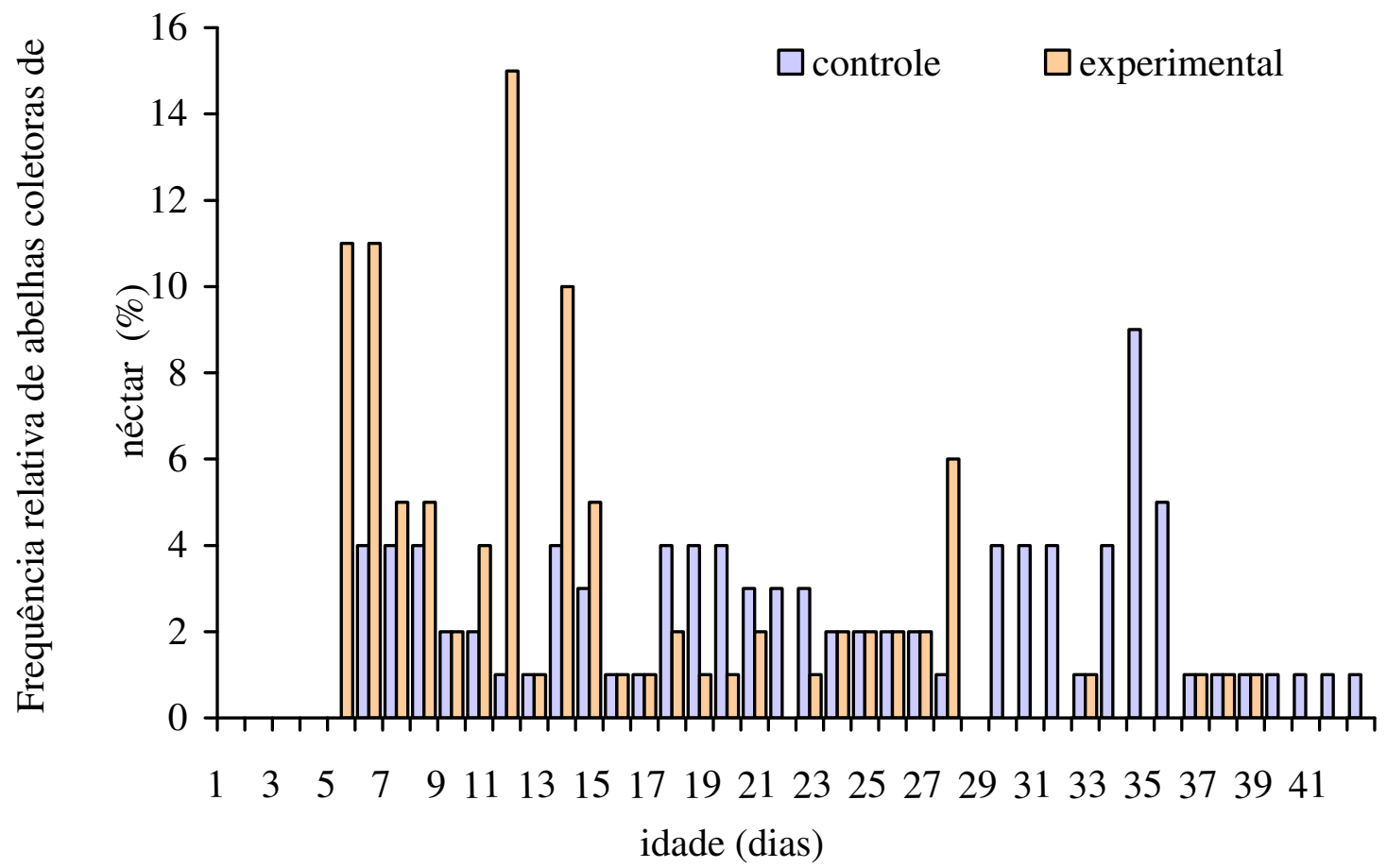

Figura 21. Freqüência relativa (\%) de operárias de abelhas africanizadas dos grupos controle e experimental que realizaram coleta de néctar.

Dentre os fatores que influenciam a coleta de alimento, é certo que a presença de rainha e crias estimula a coleta de recursos em geral, inclusive a de néctar (FREE, 1980). Além disso, a quantidade de néctar coletado está relacionada com a temperatura, umidade e nebulosidade (POLISCHUK, 1964).

De acordo com Wafa e Ibrahim (1958), a elevação da temperatura provoca um aumento no ganho de peso da colônia. Benedek (1976) estudou os efeitos das condições ambientais na atividade de forrageamento e verificou que as variações observadas dependem de um complexo sistema de fatores e não somente das diferenças climáticas, embora a temperatura tenha sido o fator de maior importância nos resultados que ele obteve.

As abelhas do grupo experimental foram mais freqüentes que as operárias do grupo controle, no que se refere à coleta de recursos alimentares. $\mathrm{O}$ período de atividade registrado para o grupo controle (de 6 a 40 dias) é semelhante ao relatado por Sakagami (1953), que observou coleta de recursos por operárias com idade entre 6 e 37 dias. Para o grupo experimental foi observado um período de atividade diferente. As abelhas desse grupo começaram a coletar precocemente e trabalharam até o $39^{\circ}$ dia de vida. No presente trabalho observou-se que o período de maior intensidade na coleta de recursos ocorreu nos últimos dias de vida das operárias, tanto no grupo controle como no grupo experimental. Portanto, se 
os dados referentes aos períodos de atividade forem analisados em função das fases de vida das operárias (início, meio e fim) e não somente relacionados à idade em que as abelhas se encontravam, pode-se concluir que houve similaridade entre os períodos de maior atividade registrados para as abelhas dos dois grupos. Os resultados obtidos nas pesquisas realizadas por Ribbands (1953) e Pereira (2002) também indicaram que o período em que as operárias realizaram maior número de coletas correspondeu à fase final de sua vida. Contudo, os dados obtidos na presente pesquisa diferem dos resultados compilados por Sakagami (1953), que observou atividade de coleta de recursos mais intensa por operárias de menor faixa etária. $\mathrm{Na}$ mencionada pesquisa as abelhas coletaram mais pólen entre 14 e 19 dias de idade, enquanto a maior atividade de coleta de néctar ocorreu entre 16 e 22 dias de vida.

Nas abelhas africanizadas há grande variação na idade em que as operárias realizam as tarefas internas do ninho e quando iniciam as coletas. As operárias que realizam os vôos de orientação mais cedo também antecipam as atividades de coleta e, por este motivo, podem abreviar ou mesmo omitir algumas tarefas na colônia (FREE, 1980). Considerando o primeiro vôo de orientação, Sakagami (1953) observou um período de forrageamento entre 5 e 39 dias de idade, enquanto Lindauer (1953) e Ribbands (1953) registraram períodos entre 20 e 41 dias e de 9 a 35 dias, respectivamente.

De acordo com os resultados obtidos no presente trabalho as abelhas do grupo experimental apresentaram maior atividade em relação à coleta de pólen. Estes resultados são semelhantes aos relatados por Grossman et al. (1945), que verificaram que a cafeína aumentou a taxa de coleta de pólen pelas abelhas, bem como o apetite para proteínas em vespas, devido ao aumento na produção de ácido hidroclorídrico e pepsina. O aumento na coleta de pólen é proporcional ao aumento na quantidade de crias, desde que haja estoques adequados de mel na colônia (FREE, 1980).

Em relação ao fluxo de saída de operárias da colméia contatou-se diferença significativa $(U=6,08 ; p<0,005)$ entre os grupos controle e experimental. No grupo controle o período de saída ocorreu entre o $6^{\circ}$ e o $40^{\circ}$ dias de vida, com um pico máximo de atividade aos 35 dias. No grupo experimental a saída das abelhas foi registrada entre o $5^{\circ}$ e o $26^{\circ}$ dias de idade, com picos de atividade máxima aos 11 e 15 dias (Figura 22). 


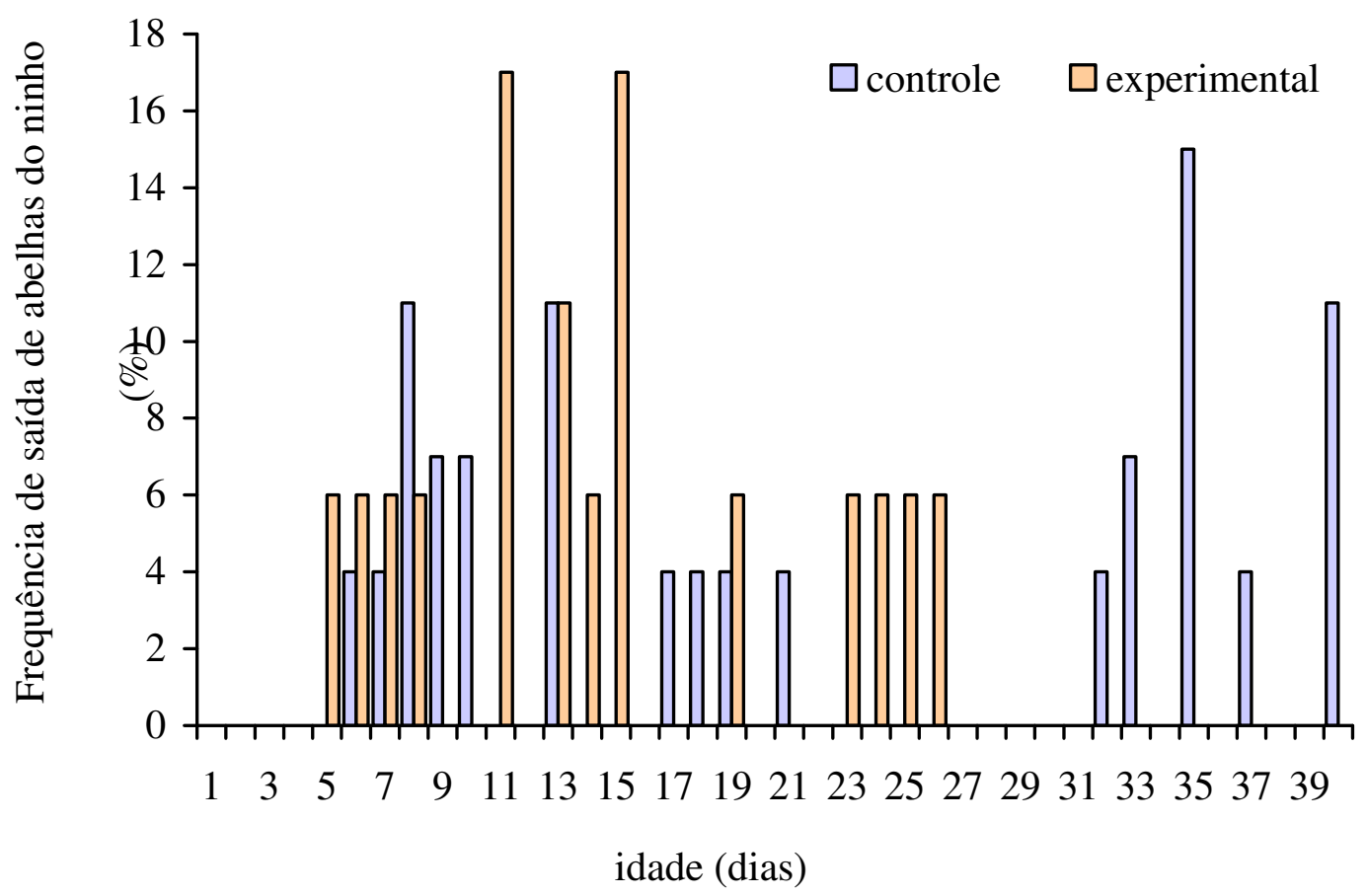

Figura 22. Freqüência relativa (\%) de operárias de abelhas africanizadas dos grupos controle e experimental que saíram da colméia.

O período de retorno das operárias à colméia se deu entre 6 e 43 dias de idade para o grupo controle e de 5 a 40 dias para o grupo experimental, mas de forma descontínua. $\mathrm{O}$ grupo experimental apresentou um pico máximo de atividade no $11^{\circ}$ dia de vida, com $17 \%$ das operárias apresentando esse comportamento. No grupo controle, a frequência máxima de operárias que retornaram a colméia (7\% do total) foi registrada no $35^{\circ}$ dia de vida. Para as operárias das outras faixas etárias as flutuações observadas foram relativamente pequenas (Figura 23). Uma análise estatística dos dados referentes ao número de abelhas que retornaram à colméia indicou uma diferença significativa $(U=5,94 ; p<0,005)$ entre os dois grupos analisados.

Foi feita uma avaliação da relação entre os dados referentes ao número de abelhas dos grupos controle e experimental, que saíram e entraram nas colméias, os recursos alimentares por elas coletados e as variáveis ambientais. As Análises de Correlação de Spearman indicaram apenas um valor significativo ( $\mathrm{rs}=-0,33)$, entre a variável pressão atmosférica $(\mathrm{mb})$ e o número de abelhas do grupo controle que entraram na colméia (Tabela 2). 


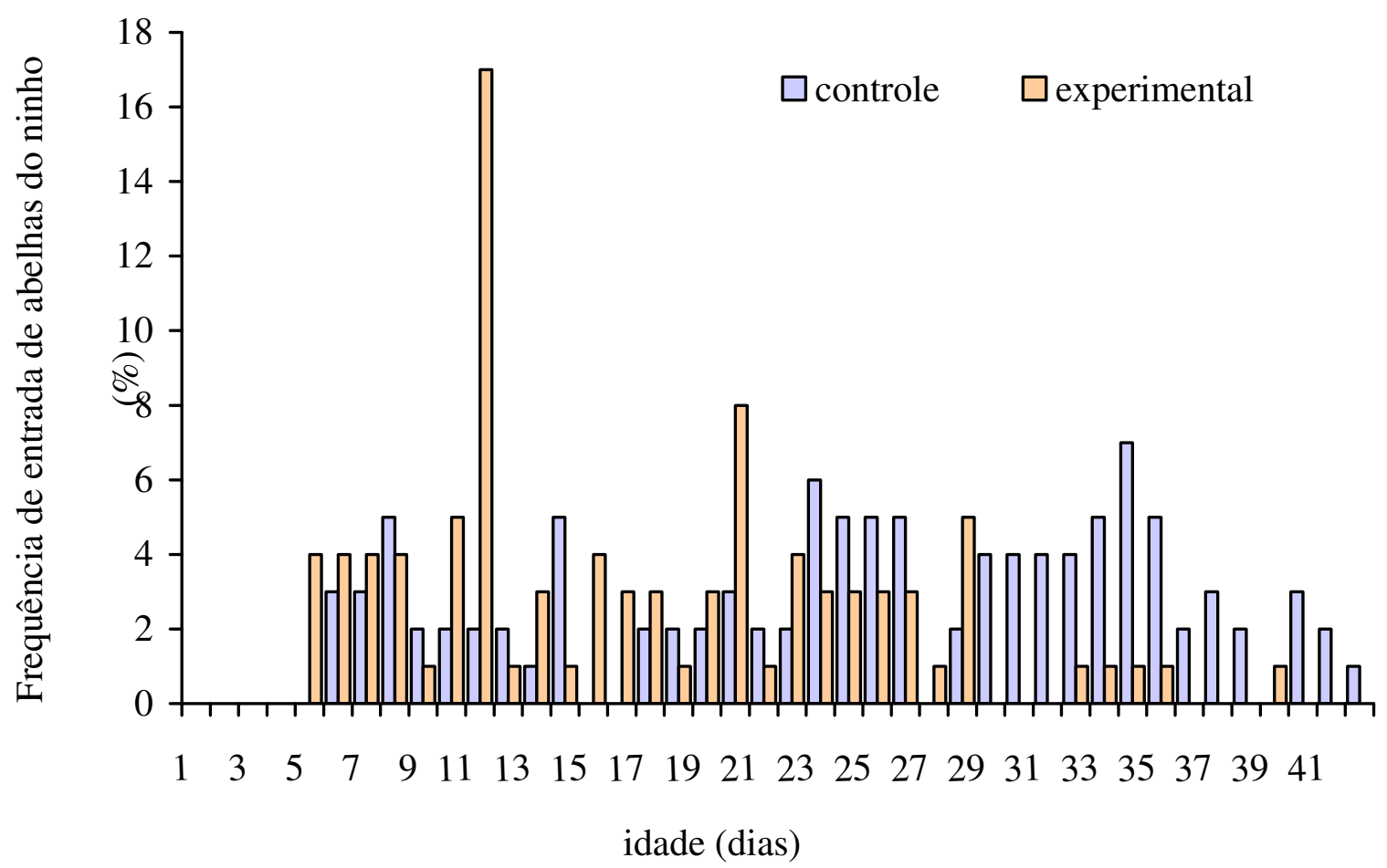

Figura 23. Frequiência relativa (\%) de operárias de abelhas africanizadas dos grupos controle e experimental que retornaram à colméia.

Tabela 2. Valores obtidos nas Análises de Correlação de Spearman (rs) entre os dados referentes ao número de abelhas que entraram e saíram das colméias, os recursos alimentares que elas coletaram e as variáveis ambientais registradas (temperatura, umidade relativa, pressão atmosférica, pluviosidade e velocidade do vento).

\begin{tabular}{lcccccc}
\hline Grupo & Variável & $\begin{array}{c}\text { Temperatura } \\
\left({ }^{\mathbf{o}} \mathbf{C}\right)\end{array}$ & $\begin{array}{c}\text { Umidade } \\
\text { Relativa } \\
(\mathbf{\%})\end{array}$ & $\begin{array}{c}\text { Pressão } \\
\text { Atmosférica } \\
(\mathbf{m b})\end{array}$ & $\begin{array}{c}\text { Pluviosidade } \\
(\mathbf{m m})\end{array}$ & $\begin{array}{c}\text { Velocidade } \\
\mathbf{d o} \text { Vento } \\
(\mathbf{k m} / \mathbf{h})\end{array}$ \\
\hline \multirow{3}{*}{ Controle } & Néctar & 0,19 & $-0,25$ & $-0,25$ & $-0,10$ & $-0,11$ \\
& Pólen & $-0,26$ & 0,12 & $-0,07$ & 0,20 & $-0,02$ \\
& Entrada & 0,16 & $-0,25$ & $-0,33^{*}$ & $-0,19$ & $-0,06$ \\
& Saída & 0,02 & $-0,10$ & $-0,20$ & $-0,08$ & 0,19 \\
\multirow{2}{*}{ Experimental } & & & & & \\
& Néctar & $-0,13$ & 0,07 & 0,01 & 0,19 & $-0,00$ \\
& Pólen & 0,14 & $-0,22$ & 0,00 & $-0,14$ & $-0,09$ \\
& Entrada & $-0,03$ & $-0,03$ & $-0,04$ & 0,09 & $-0,02$ \\
& Saída & 0,10 & $-0,01$ & $-0,01$ & $-0,17$ & 0,02
\end{tabular}

* Valor significativo ao nível de 5\% de probabilidade 
Em relação às faixas etárias nas quais as operárias realizaram as diferentes tarefas, os resultados obtidos nesta pesquisa revelaram que para atividades como limpeza (autolimpeza, limpeza de células, solicitar limpeza, limpar outra operária), inspeção, termorregulação, defesa e alimentação larval, as variações observadas entre os dois grupos de abelhas foram muito pequenas ou mesmo inexistentes. No que se refere às tarefas ser limpa por operária, construção, recepção e coleta de recursos (pólen), observou-se que as operárias do grupo experimental começaram a trabalhar mais cedo em relação às operárias do grupo controle. Em relação à idade em que as tarefas foram desenvolvidas com maior intensidade, os dois grupos apresentaram resultados similares somente para a atividade de termorregulação (Tabela 1).

\subsection{Longevidade}

Uma comparação dos dados referentes ao tempo de vida das operárias de abelhas africanizadas utilizadas nesta pesquisa indicou diferença significativa $(U=99,37 ; p<0,0001)$ entre os grupos controle e experimental. A longevidade média das abelhas do grupo controle (27,60 \pm 0,72 dias) foi maior do que a obtida para o grupo experimental (16,34 $\pm 0,72$ dias), embora a diferença entre os valores de longevidade máxima obtidos para as operárias dos dois grupos tenha sido pequena (40 dias para o grupo controle e 39 dias para o grupo experimental).

De acordo com as curvas de sobrevivência (Figura 24), observa-se que no grupo experimental a taxa de mortalidade foi bem mais acentuada do que no grupo controle, particularmente nas duas primeiras semanas de vida. Aproximadamente 50\% das abelhas do grupo experimental morreram antes de completarem 15 dias de idade. No grupo controle, no mesmo período, a taxa de mortalidade foi muito menor, sendo que aproximadamente $80 \%$ das abelhas sobreviveram até o $25^{\circ}$ dia de vida. Diferentemente do que ocorreu no grupo experimental, no grupo controle a taxa de mortalidade populacional foi menor no início da vida das operárias, com um aumento progressivo, mas mais lento, no número de abelhas mortas, à medida que elas se tornaram mais velhas. 


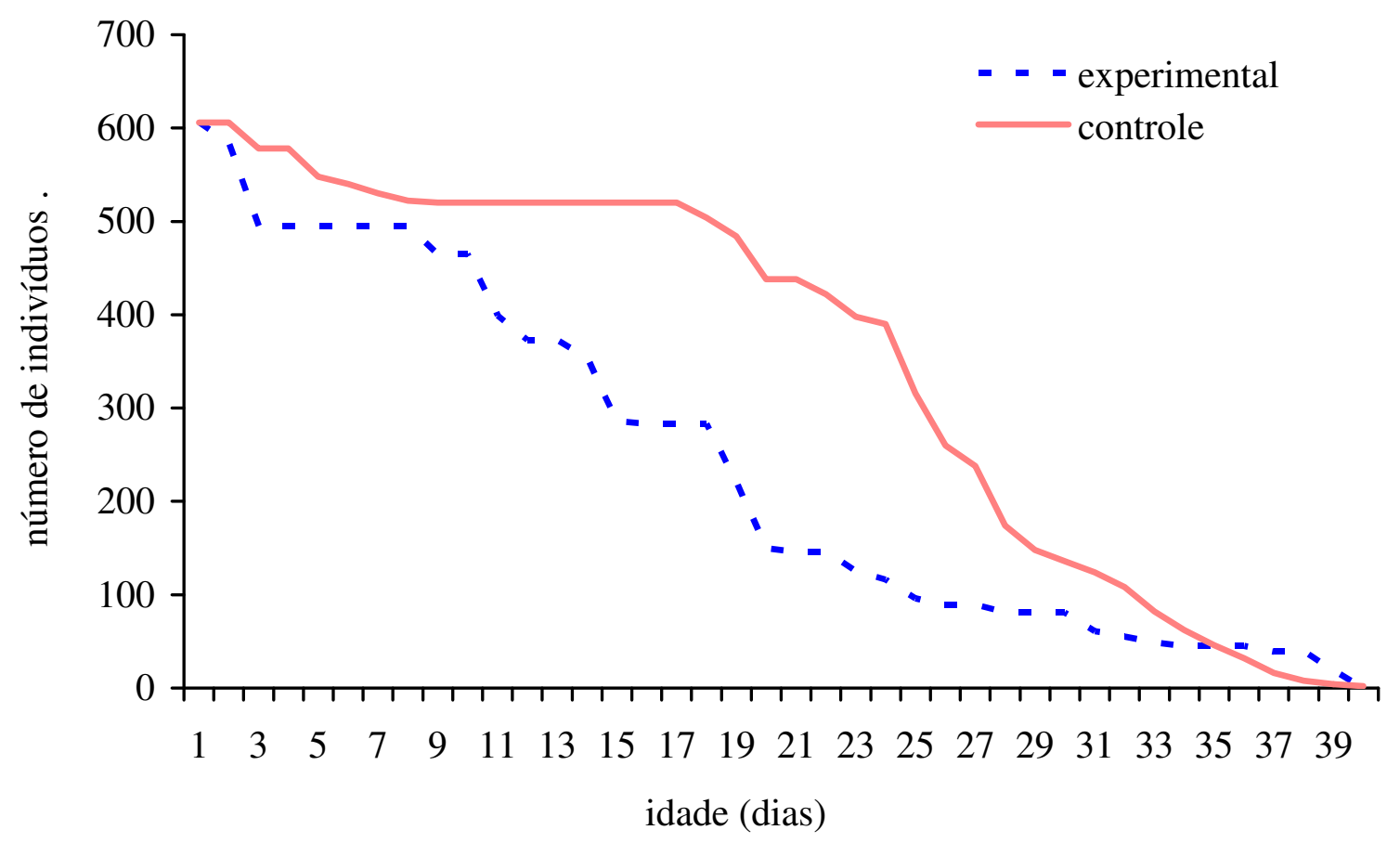

Figura 24. Curvas de sobrevivência das operárias de Apis mellifera pertencentes aos grupos controle e experimental.

Os resultados obtidos nas análises de correlação de Spearman (rs) indicam que não houve correlação significativa entre os dados de longevidade das operárias de Apis mellifera dos grupos controle e experimental e os dados referentes à temperatura externa (Figuras 25 e 26). De acordo com estes resultados pode-se concluir que a diferença de longevidade registrada entre as abelhas dos dois grupos não foi ocasionada por variações da temperatura externa. 


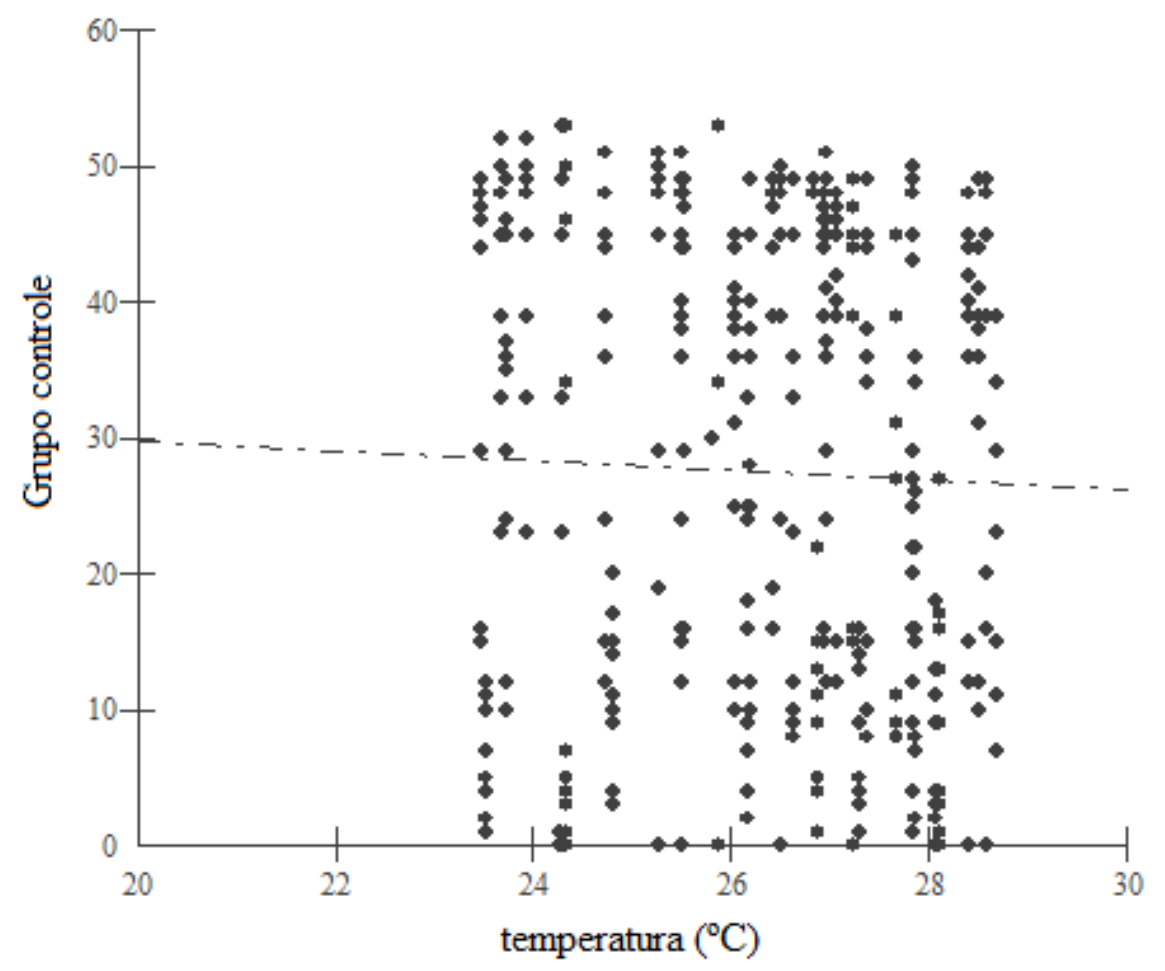

Figura 25. Resultado da análise de correlação de Spearman ( $r s=0,04 ; p>0,05$ ) entre os dados referentes à longevidade das operárias do grupo controle e a temperatura externa $\left({ }^{\circ} \mathrm{C}\right)$.

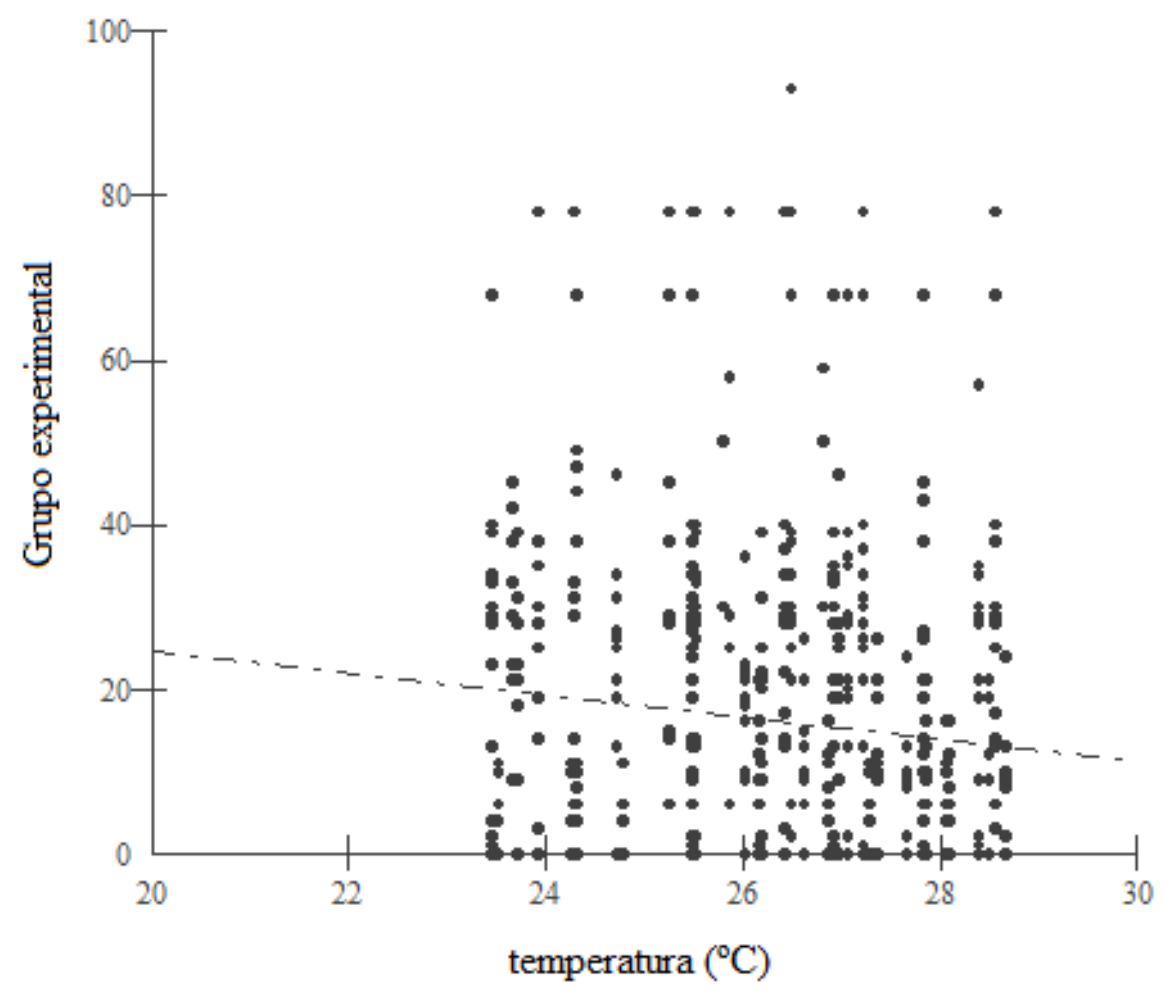

Figura 26. Resultado da análise de correlação de Spearman ( $r s=-0,08 ; \mathrm{p}>0,05)$ entre os dados referentes à longevidade das operárias do grupo experimental e a temperatura externa $\left({ }^{\circ} \mathrm{C}\right)$. 
É provável que a diferença observada entre os valores de longevidade média registrados para as operárias dos dois grupos seja resultante do comportamento de abstinência de algumas operárias do grupo experimental (13\% da população). De acordo com as curvas de sobrevivência obtidas, a mortalidade registrada nos primeiros dias de vida foi maior no grupo experimental que no grupo controle (Figura 24). A coleta de recursos é uma tarefa muito arriscada em relação às tarefas internas do ninho e o início precoce desta atividade pode ter um efeito significativo na longevidade das operárias (FREE, 1980). Ribbands (1953) verificou que as operárias que começam a realizar as atividades de coleta de recursos alimentares em uma idade mais avançada geralmente têm maior longevidade, em relação àquelas que iniciam as atividades externas à colônia precocemente. A atividade de coleta é uma tarefa difícil e desgastante. Os vôos de coleta aumentam a taxa de mortalidade das operárias, pois elas ficam sujeitas à predação ou podem não retornar à colméia ("drift"). Além disso, as mudanças repentinas das condições climáticas ocasionam envelhecimento precoce, o que também abreviará seu tempo de vida. No presente trabalho as operárias que receberam dieta enriquecida com cafeína iniciaram as atividades de coleta de recursos alimentares no segundo dia de vida. Assim sendo, o desgaste físico que estas abelhas sofreram ao longo de suas vidas deve ter sido muito maior em relação ao das abelhas do grupo controle, fazendo com que sua longevidade sofresse uma redução significativa.

Sakagami e Fukuda (1968) observaram que as abelhas que vivem em países de clima temperado apresentam dois períodos distintos de longevidade, que são estabelecidos ao longo do ano. O primeiro deles corresponde à fase ativa da colônia, quando ocorre grande fluxo de recursos alimentares e as operárias trabalham intensamente na coleta de pólen e néctar. $\mathrm{O}$ segundo período corresponde à fase de repouso ou hibernação. Em uma pesquisa realizada no Japão eles observaram que as operárias que emergiram nos meses mais quentes, quando ocorre intensa atividade de coleta, viveram de 28,3 a 32,4 dias. Por outro lado, as abelhas que emergiram no inverno, quando não são realizadas atividades de coleta, viveram em média 154,1 dias.

Southwick et al. (1990) verificaram que durante o inverno a taxa metabólica das operárias de abelhas africanizadas é muito maior porque elas precisam manter a temperatura interna do ninho. Por este motivo, ocorre uma diminuição significativa na longevidade dessas abelhas durante este período do ano.

Segundo Winston et al. (1983), a longevidade das operárias adultas de abelhas africanizadas é menor em relação à registrada para as operárias de abelhas de origem européia porque em países de clima temperado estas últimas apresentam comportamento de 
hibernação. Durante o período de inverno as abelhas européias se agrupam para realizar a termorregulação da colônia, economizando energia para executar as atividades futuras que serão desenvolvidas na primavera seguinte.

A cafeína pode ter estimulado o início precoce da coleta de recursos, pois produz efeitos estimulantes que proporcionam aumento na sensação de bem estar, fornece energia e motivação para trabalhar e permite maior concentração na atividade realizada (GRIFFITHIS et al., 1990; GRIFFITHIS e MUMFORD, 1996), além de retardar o sono (SNEL, 1993; LANDOLT et al., 1995) e aumentar a vigilância e as atividades psicomotoras (SWEDLOW et al., 1986; NEHLING et al., 1992).

É provável que o aumento da coleta de recursos no grupo experimental tenha sido influenciado pela ação da cafeína, a qual atua no sistema nervoso central por mecanismos similares aos das anfetaminas, estimulando a liberação de ß-endorfinas e hormônios que modificam a percepção de dor e desconforto causada pelo esforço físico, permitindo que essa atividade seja realizada com maior intensidade (NEHLING e DEBRY, 1994). 


\section{CONSIDERAÇÕES FINAIS}

Os resultados desta pesquisa indicaram diferenças significativas no que se refere à frequência de algumas atividades realizadas por operárias que receberam dieta normal (grupo controle) e operárias alimentadas com dieta contendo cafeína (grupo experimental), tais como: autolimpeza, limpeza de células, inspeção, termorregulação, construção, defesa da colônia e alimentação larval, bem como no que se refere à longevidade das abelhas analisadas.

A análise comparativa dos dados obtidos na pesquisa revelou que a frequência de operárias do grupo experimental que realizaram autolimpeza, recepção de alimento, alimentação larval e coleta de recursos alimentares foi maior em relação à observada no grupo controle. Por outro lado, as abelhas deste grupo foram mais assíduas na execução das tarefas de limpeza de células, inspeção, termorregulação e construção de células. Além disso, apresentaram maior longevidade em relação às abelhas do grupo experimental. Nos dois grupos estudados, a frequência de abelhas que efetuaram a atividade de defesa da colônia em diferentes idades foi muito variável, mas as abelhas do grupo controle realizaram essa tarefa até uma idade mais avançada.

As operárias do grupo experimental construíram um número de células (401) quase duas vezes maior em relação às operárias do grupo controle (208), sendo que no grupo experimental foram realizadas 811 observações referentes à execução desta tarefa, enquanto que no grupo controle foram feitos 2.522 registros dessa atividade. A cafeína estimulou as abelhas a trabalharem mais intensamente na construção de favos. Dessa forma, a adição 
controlada de cafeína na dieta alimentar das abelhas pode favorecer o aumento da exploração comercial de cera pelos apicultores.

No grupo experimental, a construção de células novas no favo resultou no aumento do número de larvas e também na coleta de recursos alimentares. O fluxo de coleta de pólen e néctar foi maior no grupo experimental (89\%) do que no grupo controle (11\%). As operárias do grupo experimental iniciaram a atividade de coleta de recursos alimentares em uma idade precoce em relação ao grupo controle, mas nos dois grupos o período de maior atividade de coleta ocorreu em uma mesma faixa etária. A saída precoce das abelhas do grupo experimental para forragear e o elevado percentual no fluxo de coleta de pólen resultaram no aumento da frequência no comportamento de limpeza corporal das operárias, entre o $3^{\circ}$ e o $9^{\circ}$ dias de vida.

No grupo experimental ocorreu uma mortalidade expressiva logo nos primeiros quinze dias de vida das operárias. Considerando que a coleta de recursos é uma tarefa muito arriscada em relação às tarefas internas do ninho, o fato de as operárias deste grupo terem iniciado essa atividade precocemente pode ter provocado uma redução significativa na sua longevidade. Isso explicaria porque as abelhas do grupo controle apresentaram uma longevidade média maior do que as operárias pertencentes ao grupo experimental.

As análises de correlação entre as variáveis ambientais e os dados de longevidade, fluxo de coleta de recursos, entrada e saída de abelhas indicaram apenas um resultado significativo entre a variável pressão atmosférica $(\mathrm{mb})$ e o fluxo de entrada de abelhas na colônia, para o grupo controle. Portanto, as diferenças observadas entre as abelhas dos dois grupos utilizados nesta pesquisa não são decorrentes da influência das variáveis ambientais, o que reforça ainda mais a hipótese de que a cafeína agiu significativamente sobre o grupo experimental.

A dependência de cafeína prejudicou as operárias no que se refere ao desenvolvimento de suas atividades, pois algumas delas não completaram algumas das tarefas internas do ninho ou até mesmo nem chegaram a realizar determinadas funções como: inspeção de células, construção, recepção de alimento e defesa da colônia.

Na presente pesquisa, 13\% das operárias do grupo experimental $(n=78)$ apresentaram sintomas de abstinência, como compulsão, agitação, alterações de sensibilidade no tegumento, falta de coordenação motora e tremores. Se os aumentos registrados na atividade de construção de células e na coleta de recursos alimentares forem superiores ao percentual de operárias que se tornam dependentes da cafeína, é recomendável a utilização deste 
suplemento na dieta das abelhas, em determinadas épocas do ano e com adição controlada, quando ocorre grande fluxo de néctar e pólen, como na primavera. 


\section{REFERÊNCIAS BIBLIOGRÁFICAS}

ALBINA, M. L.; COLOMINA, M. T.; SANCHEZ, D. J.; TORRENTE, M.; DOMINGO, J. Interactions of caffeine and restraint stress during pregnancy in mice. Experimental Biology and Medicine, Spain, v. 227, p. 779-785, 2002.

BEIG, D.; PISANI, J. F.; KERR, W. E. Capacidade estomacal das abelhas operárias de duas subespécies de Apis mellifera L. (Hymenoptera, Apoidea). Ciência e Cultura, São Paulo, v. 24, n. 5, p. 464-468, 1972.

BENEDEK, P. Effect of environmental factors on the foragin rates of honeybees in red clover fields. Zeitschrift für Angewandte Entomologie, Berlin, v. 81, n. 1, p. 14-20, 1976.

BENOWITZ, N. L. Clinical pharmacology of caffeine. Annual Review of Medicine, Palo Alto, California, v. 41, p. 277-288, 1990.

BUTLER, C. G.; CALAM, D. H. Pheromones of the honeybee - the secretion of the Nasanov gland of the worker. Journal of Insect Physiology, New York, v. 15, p. 237-244, 1969.

CALDERONE, N. W. Proximate mechanisms of age polyethism in the honey bee, Apis mellifera L. Apidologie, Les Ulis, France, v. 29, p. 127-158, 1998.

CALDERONE, N. W.; PAGE, R. E. Genotypic variability in age polyethism and task specialization in the honey bee, Apis mellifera (Hymenoptera: Apidae). Behavioral Ecology and Sociobiology, Berlin, v. 22. p. 17-25, 1988.

CARNEY, J. M. Effects of caffeine, theophylline and theobromine on sheduled controlled responding in rats. British Journal of Pharmacology, London, v. 75, p. 451-454, 1982. 
CHAUD-NETTO, J. Abandono do ninho: uma estratégia de sobrevivência das abelhas do gênero Apis. In: CRUZ-LANDIM, C.; CHAUD-NETTO, J. (eds.), Encontro Brasileiro sobre Biologia de Abelhas e Outros Insetos Sociais (Homenagem aos 70 Anos do Dr. Warwick Estevam Kerr). São Paulo: Editora UNESP, 1992. vol. esp., p. 101-105.

CONLEE, R. K. Amphetamine, caffeine and cocaine. In: LAMB, D. R.; WILLIAMS, M.H. (eds.). Ergogenics: Enhancement of Performance in Exercise and Sport. New York: Benchmark Press, 1991. p. 285-310.

CORKINS, C. I. The winter activity in the honeybee cluster. New York: Report of the Iowa State Apiarist, 1930, 108 p.

COUTO, L. A.; NOGUEIRA-COUTO, R. H. Tabelas de vida de operárias de Apis mellifera africanizadas. Ciência Zootécnica, Jaboticabal, v. 5, n. 1, p. 3-5, 1990.

DALY, J. W. Mechanism of action of caffeine. In: GARATTINI, S. (ed.), Coffee: caffeine and health. New York: Raven Press, 1993. p. 97-150.

DALY, J. W.; BRUNS, R. E.; SNYDER, S. H. Adenosine receptors in the central nervous system: relationship to the central actions of methylxanthines. Life Science, Washington D.C., 28, p. 2083-2097, 1981.

D'AMICIS, A.; VIANI, R. The consumption of coffee. In: GARATTINI, S. (ed.), Coffee: caffeine and health. New York: Raven Press, 1993. p. 1-16.

DIXON, S. E.; MOSER, E. Duality in function in corpora allata of honeybee larvae. Canadian Journal of Zoology, Canada, v. 50, p. 593-595, 1972.

EISCHEN, F. A.; ROTHENBUHLER, W. C.; KULINCEVIC, J. M. Length of life and dry weight of worker honeybees reared In colonies with different worker-larva ratios. Journal of Apicultural Research, Cardiff, v. 21, p. 19-25, 1982,

ESKENAZI, B.; STAPLETON, A. L.; KHARRAZI, M.; CHEE, W. Y. Associations between maternal decaffeinated coffee comsumption and fetal growth and gestational duration. Epidemiology, Oxford, v. 10, p. 242-249, 1999.

ESSING, D., COSTILL, D. L.; VAN HANDEL, P. J. Effects of caffeine ingestion on utilization of muscle glycogen and lipid during leg ergometer cycling. Medicine and Science in Sports and Exercise, Indianapolis, v.1, p. 86-90, 1980.

FINN, I. B.; HOLTZMAN, S. G. Tolerance to caffeine induced stimulation of locomotor activity in rats. Journal of Pharmacology and Experimental Therapeutics, Bethesda, v. 238, p. 542-546, 1986.

FREDHOLM, B. B. Adenosine, adenosine receptors and actions of caffeine. Pharmacology and Toxicology, Utah, v.76, p. 93-101, 1995.

FREE, J. B. Factors determining the collection of pollen by honeybee foragers. Animal Behavior, New York, v. 15, n. 1, p. 134-144, 1967. 
FREE, J. B. A organização social das abelhas (Apis). São Paulo: EPU - EDUSP, 1980. Coleção Temas de Biologia, v.13, 79 p.

FREE, J. B.; PREECE, D. A. The effect of the size of a honeybee colony on its foraging activity. Insectes Sociaux, Paris, v. 16, n.1, p. 73-78, 1969.

FREE, J. B.; SPENCER-BOOTH, Y. The longevity of worker honey bees (Apis mellifera). Proceedings of the Royal Entomological Society of London (A), London, v. 34, p. 141$150,1959$.

FREE, J. B.; WILLIAMS, I. H. Exposure of the Nasanov gland by honeybees (Apis mellifera) collecting water. Behavior, Cambridge, v. 37, p. 286-290, 1970.

FRUMHOFF, P. C.; BAKER, J. A genetic component to division of labour within honey-bee colonies. Nature, London, v. 333, p. 358-361, 1988.

FUKUDA, H.; SAKAGAMI, S. F. Worker brood survival in honeybees. Research on Population Ecology, Kyoto, Japan, v. 10, p. 31-39, 1968.

GARRET, B. E.; GRIFFITHIS, R. R. The role of dopamine and the behavioral effects of caffeine in animals and humans. Pharmacology Biochemistry and Behavior, New York, v. 57, n. 3, p. 533-541, 1997.

GLASS, R. M. Caffeine dependence: what are the implications? Journal of the American Medical Association, Chicago, v.272, p.1043-1048, 1994.

GONÇALVES, L. S. A study of orientation information given by one trained bee by dancing. Journal of Apicultural Research, Cardiff, v.8, n.3, p. 113-132, 1969.

GONÇALVES, L. S. The economic impact of the Africanized Honey Bee in South America. In: BREED, M. D.; MICHENER,C. D.; EVANS, H. E. (eds.). The Biology of Social Insects. CONGRESS OF THE INTERNATIONAL UNION FOR THE STUDY OF SOCIAL INSECTS, 9th, 1982, Boulder, Colorado. Proceedings.....Westview Press,1982. p. 134-137.

GONÇALVES, L. S.; STORT, A. C. Honeybee improvement through behavioral genetics. Annual Review of Entomology, Palo Alto, v. 31, p. 197-213, 1978.

GONÇALVES, L. S.; KERR, W. E.; CHAUD-NETTO, J.; STORT, A. C. Tradução e Comentários do "Relatório Final do Grupo de Estudo Americano sobre as Abelhas Africanas". In: CONGRESSO BRASILEIRO DE APICULTURA, 2º 1972, Sete Lagoas. Anais... Sete Lagoas: Associação Mineira de Apicultores, 1972. p. 209-253.

GRAHAN, T. E.; RUSH, J. W. E.; SOEREN, M. H. Caffeine and exercise: metabolism and performance. Canadian Journal of Physiology, Canada, v.19, p. 111-138, 1994.

GREDEN, J. F. Anxiety or caffeinism: a diagnostic dilemma. American Journal of Psychiatry, Arlington, v.131, p. 1089-1092, 1974. 
GRIFFITHIS, R. R.; MUMFORD, G. K. Caffeine - A drug of abuse. In: BLOOM, F. E.;KUPFER, D. J. (eds.) Psychopharmacology: the fourth generation in progress. New York: Raven Press, 1995. p. 1699-1713.

GRIFFITHIS, R. R.; MUMFORD, G. K. Caffeine reinforcement, discrimination, tolerance and physical dependence in laboratory animals and humans. In: SCHUSTER, C. R.; KUHAR, M. J. (eds.). Pharmacological aspects of drug dependence: Toward an integrated neurobehavioral approach. Handbook of experimental pharmacology. New York: SpringerVerlag, 1996, p. 15-341.

GRIFFITHIS, R. R.; WOODSON, P. P. Caffeine physical dependence: a review of human and laboratory animal studies. Psychopharmacology, New York, v. 94, p. 437-451, 1988.

GRIFFITHIS, R. R.; BIGELOW, G. E.; LIEBSON, I. A.; O'KEEFFE, M.; O'LEARY, D.; RUSS, N. Human coffee drinking: manipulation of concentration and caffeine dose. Journal of Experimental Analysis of Behavior, Bethesda, v. 45, p.133-148, 1986.

GRIFFITHIS, R. R.; EVANS, S. M.; HEISHAMAN, S. J.; PRESTON, K. L.; SANNERUD, C. A.; WOLF, B.; WOODSON, P. P. Low-dose caffeine discrimination in humans. Journal of Pharmacology and Experimental Therapeutics, Bethesda, v. 252, p. 970 - 978, 1990.

GROSSMAN, M.; ROTH, J. M.; IWY, A. C. Pepsin secretion in response to caffeine. Gastroenterology, New York, v. 4, p.251-256, 1945.

HOLTZMAN, S. G. Complete, reversible, drug, specific tolerance to stimulation of locomotor activity by caffeine. Life Science, Washington D.C., v. 33, p. 779-787, 1983.

HOLTZMAN, S. G.; FINN, I. B. Tolerance to behavioral effects of caffeine in rats. Pharmacology Biochemistry and Behavior, New York, v. 29, p. 411-418, 1988.

IBRAHIM, S. H.; SELIM, H. A. Honeybee activity in gathering pollen from corn plants zeamays. Agricultural Research Review, Cairo, v. 5, n.1, p. 1074-113, 1972.

ISHAY, J. S.; PANIRY, V. A. Effects of caffeine and various xanthines on hornets and bees. Psychopharmacology, New York, v. 65, n. 3, p. 299-309, 1979.

ITOYAMA, M. M.; BICUDO, H. E. M. C. Effects of caffeine on fecundity, egg laying capacity, development time and longevity in Drosophila prosaltans. Revista Brasileira de Genética, Ribeirão Preto- SP, v.15, n. 2, p. 303-315, 1992.

IVY, J. L.; COSTILL, D. L.; FINK, W. J.; LOWER, R. W. Influence of caffeine and carbohydrate feedings on endurance performance. Medicine and Science in Sports and Exercise, Indianapolis, v. 11, n. 1, p. 6-11, 1979

JACOBSON, B. H.; KULLING, F. A. Health and ergogenics effects of caffeine. British Journal of Sports Medicine, London, v. 23, p. 34-40, 1989.

JAYCOX, E. R. Honeybee foraging behavior: Responses to queens, larvae, and extracts of larvae. Annals of the Entomological Society of America, Lanham, v. 63, n. 6. p. 1689-1694, 1970 a. 
JAYCOX, E. R. Honeybee queen pheromones and worker foraging behavior. Annals of the Entomological Society of America, Lanham, v.63, n.1, p. 222-228, 1970b.

KERR, W. E. The history of the introduction of African bees to Brazil. South African Bee Journal, Hatfield, Pretoria, v. 39, p. 3-5, 1967.

KERR, W. E. Comunicação nas abelhas. In: CONGRESSO BRASILEIRO DE APICULTURA, 3ㅇ 1974, Piracicaba, Anais... Piracicaba: Escola Superior de Agricultura Luiz de Queiroz, 1974, p. 97-106.

KERR, W. E.; GONÇALVES, L. S.; BLOTTA, L. F.; MACIEL, H. B. Biologia Comparada entre as abelhas italianas (Apis mellifera ligustica), africana (Apis mellifera adansonii) e suas híbridas. In: CONGRESSO BRASILEIRO DE APICULTURA, $1^{\circ}$, 1970, Florianópolis. Anais... Florianópolis: Confederação Brasileira de Apicultura, 1970. p. 151-185

KOLMES, S. A.; WINSTON, M. L.; FERGUSSON, L. A. The division of labour among worker honey bees (Hymenoptera: Apidae): the effects of multiple patrilines. Journal of Kansas Entomological Society, Kansas, v. 62, p. 80-95, 1989.

KULINCEVIC, J. M.; ROTHENBUHLER, W. C. Selection for length of life in the honeybee (Apis mellifera). Apidologie, Les Ulis, France, v. 13, n. 4, p. 347-352, 1982.

LANDOLT, H. P.; DIJK, D. J.; GAUS, S. E.; BORBELY, A. A. Caffeine reduces lowfrequency delta activity in the human sleep EEG. Neuropsychopharmacology, Cambridge, v.12, p. 229-238, 1995.

LAPERUTA, L. Di C. Efeito da cafeína no desenvolvimento ovariano de operárias de abelhas africanizadas (Apis mellifera $\mathbf{L}$.) em colônias recém-orfanadas. 41 p. Trabalho de Conclusão de Curso (Graduação em Ciências Biológicas) - Instituto de Biociências, Universidade Estadual Paulista “Júlio de Mesquita Filho”, Rio Claro, 2005.

LINDAUER, M. Die Temperaturregulierung der Bienen di Stocküberhitzung. Naturwissenschaften, Berlin, v.38, p. 308-309, 1951.

LINDAUER, M. Ein Beitrag zur Frage der Arbeitsteilung im Bienenstaat. Zeitschrift Vergleichende Physiology, Berlin, v. 36, p. 299-345, 1952.

LINDAUER, M. Division of labour in honey bee colony. Bee World, Cardiff, v. 34, p. 63-73, p.85-90, 1953.

LINDAUER, M. Communication among social bees. Cambridge Massachusetts: Harvard University. Press, 1961. 143p.

LINDAUER, M.; SCHIRIKER, B. Uber die funtion der ocellen bei den dammerungsflugen der honigbiene. Biology Zentrum, Freeburg, Germany, v.82, p. 721-725, 1963.

LINTS, F. A. Longevity: a trait under genetic control? Experientia, Basileia, Suiça, v. 37, p. 1046-1050, 1981. 
MACKENSEN, O.; NYE, W. P. Selecting and breeding honeybees for collecting alfalfa pollen. Journal of Apicultural Research, Cardiff, v.5, p. 79-86, 1966.

MACKENSEN, O.; NYE, W. P. Selective breeding of honey bees for alfalfa pollen collection: sixty generation and outcrosses. Journal of Apicultural Research, Cardiff, v. 8, p. 9-12, 1969.

MALASPINA, O. Análise do comportamento de coleta de alimento e morfometria em abelhas africanizadas, caucasianas e em descendentes dos seus cruzamentos. 163 p. Tese (Doutorado em Ciências Biológicas), Instituto de Biociências, Universidade Estadual Paulista "Júlio de Mesquita Filho", Rio Claro, 1982.

MAURIZIO, A. The influence of pollen feeding and brood rearing on the length of life and physiological condition of the honeybee. Bee World, Cardiff, v. 31, p. 9-12, 1950.

MEKHAIL-ISHAK, K.; LAVOIE, P. A.; SHARKAWI, M. Effects of caffeine and cyclic adenosine 3',5'- monophosphate on adenosine triphosphate-dependent calcium uptake by lysed brain synaptosomes. Brain Research Review, Bethesda, v. 426, n. 1, p. 62-8, 1987.

MICHENER, C. D. The social behaviour of the bees: A comparative study. Cambridge Massachusetts: The Belknap Press of Harvard University Press, 1974. 404 p.

MILNE, C. P. Jr. Laboratory measurement of honey production in the honeybee. 2. Longevity or length of life of caged workers. Journal of Apicultural Research, Cardiff, v. 19, p. 172$175,1980$.

MILNE, C. P. Jr. An estimate of the heritability of worker longevity or length of life in the honeybee. Journal of Apicultural Research, Cardiff, v. 24, p. 140-143, 1985.

MINATTI, E. Cafeína: a droga predileta. Revista Eletrônica do Departamento de QuímicaUFSC, Ano 3, n. 53. 2002. Disponível em: http://www.qmc.ufsc.br/qmcweb/exemplar22.html. Acessado em: 8 de out. 2007.

MORITZ, R. F. A.; SOUTHWICK, E. E. Bees as superorganisms: an evolutionary reality. Berlin: Springer-Verlag, 1992. 395 p.

NASCIMENTO-JÚNIOR, A. F. Estudo comparativo enxameatório, migratório e do desenvolvimento de colméias de abelhas africanizadas. 88 p. Dissertação (Mestrado em Genética), Faculdade de Medicina de Ribeirão Preto, Universidade de São Paulo, Brasil, 1981.

NEHLING, A.; DEBRY, G. Potential teratogenic and neurodevelopmental consequences of coffee and caffeine exposure: a review on human and animal data. Neurotoxicology and Teratology, New Jersey, v. 16, p. 531-543, 1994.

NEHLING, A.; DAVALL, J. L.; DEBRY, G. Caffeine and the central nervous system: mechanism of action, biochemical, metabolic and psychostimulant effects. Brain Research Review, Bethesda, v.17, p.139-170, 1992. 
NEVES-FERMIANO, L. H. M. Estudo do comportamento de coleta de alimento em duas subespécies de Apis mellifera (Hymenoptera, Apidae) e nos descendentes F1 resultantes de seu cruzamento. 88f. Dissertação (Mestrado em Genética), Faculdade de Medicina de Ribeirão Preto, Universidade de São Paulo, Ribeirão Preto, 1981.

NOGUEIRA-NETO, P. Notas sobre a história da apicultura brasileira. In: CAMARGO, J. M. F. (ed.). Manual de Apicultura. São Paulo: Editora Agronômica Ceres Ltda., 1972. p. 134137.

NUÑEZ, J. A. Estudio cuantitativo del comportamiento de Apis mellifera ligustica Spinola, y Apis mellifera adansonii Latreille. Factores energéticos y informacionales condicionantes y estrategia del trabajo recolector . Ciência e Cultura, São Paulo, v. 26, n. 8, p. 786-797, 1974.

NUÑEZ, J. A. Circadian variation of light activity in colonies of Apis mellifera ligustica. Journal of Insect Physiology, New York, v. 23, n.3, p. 387-392, 1977.

NUÑEZ, J. A. Comparative study of thermoregulation between european and africanized Apis mellifera in Brazil. Journal of Apicultural Research, Cardiff, v.18, n. 2, p. 116-121, 1979.

NYE, W.P.; MACKENSEN, O. Preliminary report on selection and breeding of honeybees for alfalfa pollen collection. Journal of Apicultural Research, Cardiff, v. 4, p. 43-48, 1965.

NYE, W. P.; MACKENSEN, O. Selective breeding of honeybees for alfalfa pollen: fifth generation and back-crosses. Journal of Apicultural Research, Cardiff, v.7, p. 21-27, 1968.

NYE, W. P.; MACKENSEN, O. Selective breeding of honeybees for alfalfa pollen collection with tests in high and low alfalfa pollen regions. Journal of Apicultural Research, Cardiff, v. 9, p. 61-64, 1970.

PAGE, R. E.; ROBINSON, G. E. The genetics of division of labour in honey bee colonies. Advances in Insect Physiology, New South Wales, Austrália, v. 23, p. 118-168, 1991.

PAGE, R.E.; ROBINSON, G. E.; FONDRK, M. K. Genetic specialists, kin recognition and nepotism in honey-bee colonies. Nature, London, v. 338, p. 576-579, 1989 a.

PAGE, R. E.; ROBINSON, G. E.; CALDERONE, N. W.; ROTHENBUHLER, W. C. Genetic structure, division of labor, and the evolution of insect societies. In: BREED, M. D.; PAGE, R. E. (eds.) The genetics of social evolution. Boulder, CO, Westview Press, 1989 b. p. 15-29 b.

PALFAIT, T.; JANKIEWICZ, H. Drugs and human behavior. Dubuque, IA: Brown, 1991. $527 \mathrm{p}$.

PARDO, A. M.; CORTES, M. C.; ARMSTRONG, D. P.; ORELlANA, E. A. M.; SOTO, G. M.; PRIETO, J. P. Manejo y control de la abeja africanizada. El Salvador, 1988. 229 p.

PASMAN, W. J.; BAAK, M. A.; JEUKENDRUP, A. E.; HAAN, A. The effect of different dosages of caffeine on endurance performance time. International Journal of Sports and Medicine, New York, v.16, n. 4, p. 225-330, 1995 
PEREIRA, A. M. Divisão de trabalho em colônias mistas de Apis mellifera. 65p. Trabalho de Conclusão de Curso (Graduação em Ciências Biológicas) - Instituto de Biociências, Universidade Estadual Paulista "Júlio de Mesquita Filho”, Rio Claro, 2002.

PEREIRA, A. M.; CHAUD-NETTO, J. Hymenoptera marking technique. Journal of Venomous Animals and Toxins Including Tropical Diseases, Botucatu, v. 14, n.1, p. 166$169,2008$.

PEREPELOVA, L. Materials concerning the biology of the bee: the work of the bees in the hive. Opuit Paseka, Tula, n.11, p. 492-502, 1928.

PHILLIPS, E. F.; DEMUTH, G. S. The temperature of the honeybee cluster in winter. Bulletin of the United States Department of Agriculture, New York, v. 93, p. 1-16, 1914.

POLISCHUK, V. P. The influence of certain factors on nectar collection from flowers. Bdzhil' nitsvo, [S.I], v.1, p.79-82, 1964.

REGINATO, R. D.; CRUZ-LANDIM, C. Desenvolvimento ovariano em larvas de operárias de Apis mellifera L. (Hymenoptera, Apidae). In: ENCONTRO SOBRE ABELHAS, n. 3, 1998, Ribeirão Preto. Anais... Ribeirão Preto: Editora Universidade de Ribeirão Preto,1998. p. 122-127.

REGINATO, R. D.; CRUZ-LANDIM, C. Differentiation of the worker's ovary in Apis mellifera L. (Hymenoptera, Apidae) during life of the larvae. Investment and Development, San Francisco, v. 39, p.127-134, 2001.

REGINATO, R. D.; CRUZ-LANDIM, C. Morphological characterization of cell death during the ovary differentiation in worker honeybees. Cell Biology International, London, v. 26, p. 343-351, 2002.

RIBBANDS, C. R. Division of labour in the honey bee community. Proceedings of the Royal Society of London, Oxford, v. 140, p. 32-43, 1952.

RIBBANDS, C. R. The behavior and social life of honeybees. London: Bee Research Association, 1953, $352 \mathrm{p}$.

RINDERER, T. E.; SYLVESTER, H. A. Variation in response to Nosema apis, longevity and hoarding behavior in a free-mating population of the honey bee. Annals of the Entomological Society of America, Lanham, v. 71, p. 372-374, 1978.

RITCHIE, J. M. Central nervous system stimulants: The Xanthines. In: GOODMAN, L. S.; GILMAN, A. (eds.). The Pharmacological Basis of Therapeutics. New York: Macmillan, 1975. p. 367-378.

RIZZINI, C. T. Tratado de fitogeografia do Brasil. São Paulo: EDUSP, 1976, 326 p.

ROBINSON, G. E.; PAGE, R. E. Genetic basis for division of labour in an insect society. In: BREED, M. D.; PAGE, R. E. (eds.) The genetics of social evolution. Boulder, CO, Westview Press, 1989, p. 61-80. 
RÖSCH, G. A. Untersuchungen über die Arbeitsteilung im Bienenstaat. I. Die Tätigkeiten im normalen Bienenstaate und ihre Beziehungen zum Alter der Arbeitsbienen. Zeitschrift Vergleichende Physiology, Berlin, v.2, p. 571-631, 1925.

RÖSCH, G. Ueber die Bautätigkeit im Bienenvolk und das Alter der Baubienen. Weiterer Beitrag zur Frage nach der Arbeitsteilung im Bienenstaat. Zeitschrift Vergleichende Physiology, Berlin, v. 6, p. 265-298, 1927.

RÖSCH, G. A. Untersuchungen über die Arbeitsteilung im Bienenstaat. II. Die Tätigkeiten der Arbeitsbienen unter experimentell veränderten Bedingungen. Zeitschrift Vergleichende Physiology, Berlin, v.12, p. 1-71, 1930.

ROTHENBUHLER, W. C.; PAGE JR., R. E. Genetic variability for temporal polyethism in colonies consisting of similarly-aged worker honey bees. Apidologie, Les Ulis, France, v. 20, n. 5, 433-437, 1989.

ROTH, M. La production de chaleur chez Apis mellifera. Annales de l' Abeille, Les Ulis, France, v. 8, p. 5-77, 1965.

RUTTNER, F. 1986. Geographical variability and classification. In: RINDERER, T. E. (ed.). Bee genetics and breeding. Orlando: Academic Press, 1986. p. 23-56.

SAKAGAMI, S. F. Untersuchungen über die arbeitsteilung in einem zwergvolk der homigbiene. Beiträge zur biologie des bienenvolkes, Apis mellifera L., Japanese Journal of Zoology, Tokyo, v. 11, p. 117-185, 1953.

SAKAGAMI, S.F.; FUKUDA, H. Life tables for worker honeybees. Research on Population Ecology, Kyoto, Japan, v.10, n.2, p.127-139, 1968.

SAWYNOK, J.; YAKSH, T. L. Caffeine as na analgesic adjuvant: a review of pharmacology and mecanisms of action. Pharmalogical Reviews, Bethesda, v. 45, n. 1, p. 43-51, 1993.

SCHRIKER, B. Die orientierung der honigbiene in der dammerung zugleich ein beitrag zur frage der ocellen-funktion bei bienen. Zeitschrift Vergleichende Physiology, Berlin, v. 49, p. $420-458,1965$.

SCHMIDT, L. M.; CAPELLA, L. C.; HARTFELDER, K. Juvenile hormone effect on DNA synthesis and apoptosis in caste-specific differentiation of the larval honey bee (Apis mellifera L.) ovary. Journal of Insect Physiology, New York, v. 44, p. 385-391, 1998.

SEELEY, T. D. Measurement of nest cavity volume by the honey bee (Apis mellifera). Behavior Ecology and Sociobiology, Berlin, v. 2, p. 201-227, 1977.

SEELEY, T. D. Life history strategy of the honey bee, Apis mellifera. Oecologia, Berlin, v. 32, p. 109-118, 1978.

SEELEY, T. D. Adaptive significance of the age polyethism schedule in honeybee colonies. Behavior Ecology and Sociobiology, Berlin, v. 11, p. 287-293, 1982. 
SEELEY, T. D. Honeybee ecology: a study of adaptation in social life. New Jersey: Princeton University Press, USA, 1985. 201 p.

SEELEY, T. D.; MORSE, R. Nest site selection by the honey bee, Apis mellifera. Insectes Sociaux , Paris, v. 25, n.4, p. 323-337, 1978.

SEHGAL, S. S.; SIMÕES, L. C. G. Preliminary results on the effects of neutropic drugs on Drosophila melanogaster. Ciência e Cultura, São Paulo, v. 28, n. 8, p. 917-920, 1976.

SEHGAL, S. S.; SIMÕES, L. C. G.; JURAND, A. Effects of caffeine on growth and metamorphosis of moth fly Telmatoscopus albipunctatus (Diptera, Psychodidae). Entomologia Experimentalis et Applicata, Netherlands, v. 21, p. 174-181, 1977.

SHILDKRAUT, J. J.; WATSON, R. K.; DRASKOCZY, P. R. Amphetamine withdrawal: Depression and MHPG excretion. Lancet, UK, v. 2, p. 485-486, 1971.

SMYTH JR., T. Muscle systems. In: M.S. BLUM (ed.). Fundamentals of insect physiology. Philadelphia: Wiley-Interscience Publication, 1985. p. 227-252.

SNEL, J. Coffee and caffeine, sleep and wakefulness. In: GARATTINI, S. (ed.). Coffee: caffeine and health. New York: Raven Press, 1993, p. 255-290.

SNYDER, S. H.; KATINS, J. J.; ANNAU, A.; BRUNS, R. F.; DALY J. W. Adenosine receptors and the behavioral actions of methylxanthines. Proceedings of the National Academy of Sciences, USA, v. 78, p. 3260-3264, 1981.

SOARES, A. E. E.; MICHELETTE, E. R. F.; DINIZ, N. M.; TEIXEIRA, M. V. Dispersão das abelhas africanizadas nas Américas: aspectos comportamentais. In: CONGRESSO BRASILEIRO DE APICULTURA, 10 . PROCEEDINGS... Pousada do Rio Quente: Confederação Brasileira de Apicultura, 1994. p. 157-186.

SOMMER, P. S. M. Fatores que afetam a ontogenia do comportamento em Apis mellifera (Hymenoptera, Apidae). 119 f. Dissertação (Mestrado em Genética). Faculdade de Medicina de Ribeirão Preto, Universidade de São Paulo, Ribeirão Preto, 1986.

SOUTHWICK, E. E.; ROUBIK, D. W.; WILLIAMS, J. M. Comparative energy balance in groups of Africanized and European honey bees: ecological implications. Comparative Biochemistry and Physiology, New York, v. 97, p. 1-7, 1990.

STEINER, A. Der wärmehaushalt de einheimischen sozialen hautflüger. Beiheft Schweizerische Bienen - Zeitung, Sauerländer, v. 2, p. 139-259, 1947.

STORT, A. C. Estruturas sensoriais e comportamento agressivo em abelhas do gênero Apis. In: CONGRESSO BRASILEIRO DE APICULTURA, 3o 1974, Piracicaba, Anais..... Piracicaba: Escola Superior de Agricultura Luiz de Queiroz, 1974, p. 93-95.

STORT, A. C.; GONÇALVES, L. S. A africanização das abelhas Apis mellifera nas Américas. In: BARRAVIERA, B. (ed.). Venenos animais: uma visão integrada. Rio de Janeiro: EPUC, 1994. p. 33-47. 
STRINGER, K. A.; WATSON, W. A. Caffeine withdrawal symptoms. The American Journal of Emergence Medicine, New York, v. 5, n., p. 469, 1987.

SWEDLOW, N. R.; VACCARINO, F. J.; AMALRIC, M.; KOOB, G. F. The neural substrates for the motor activating properties of psychoestimulants: A review of recent findings. Pharmacology Biochemistry and Behavior, New York, v.25, p. 233-248, 1986.

TARANOV, G. F. The production of wax in the honeybee colony. Bee World, Cardiff, v. 40, p. 113-121, 1959.

TARANOV, G.F.; SEDIN, I.F. The behaviour of foraging bees during an extended flow. 21; In: INTERNATIONAL BEEKEEPING CONGRESS, Paper 114, 1967, Thimpu, Bhutan. Anais... Thimpu, Bhutan, 1967. p. 129-133, p. 629-667.

TARNOPOLSKY, M. A. Caffeine and endurance performance. Sports and Medicine, London, v.18, n. 2, p. 109-125, 1994.

TERADA, Y.; GARÓFALO, C. A.; SAKAGAMI, S. F. Age-survival curves for workers of two eusocial bees Apis mellifera and Plebeia droryana in a subtropical climate, with notes on queen polyethism in $P$. droryana. Journal of Apicultural Research, Cardiff, v. 14, n. 3/4, p. 161-170, 1975.

THITHAPANDHA, A.; MALING, H. M.; HILLETTE, J. R. Effects of caffeine and theophyline on activity of rats in relation to brain xanthine concentrations. Proceedings of the Society of Experimental Biology and Medicine, Oxford, v. 139, p. 582-586, 1972.

THOMPSON, R. F. Introduction to physiological psychology. New York: Harper International Edition, 1971. 669p.

VERGERON, P. La cire d'abeille, sa chimie et sa biosynthèse, son utilization dans la ruche. Science Program, California, v. 3391, p. 428-432, 1967.

VILLA, J. D. Africanized and European colony conditions at different elevations in Colombia. American Bee Journal, Hamilton, v. 127, p. 7-53, 1987.

VLAJINAC, H. D.; PETROVIC, R. R.; MARINKOVIC, J. M.; SIPETIC, S. B.; ADANJA, B. J. Effect of caffeine intake during pregnancy on birth weight. American Journal of Epidemiology, Oxford, v.145, p. 335-338, 1997.

WADDINGTON, K. D. Foraging behavior of pollinators. In: WADDINGTON, K. D. (ed.) Pollination Biology. London: Academic Press Inc., 1983. p. 213-239.

WAFA, A. K. E IBRAHIM, S. H. Temperature as a factor affecting nectar gathering activity in Egypt. Bulletin of the Faculty of Agriculture at University of Cairo, Cairo, 14 p., 1958.

WATSON, R.; BAKOS, L.; COMPTON, P.; GAWIN, F. Cocaine use and withdrawal: the effect on sleep and mood. American Journal of Drug and Alcohol Abuse, Houston, v. 18, p. 21-28, 1992. 
WATSON, R.; HARTMAN, E.; SCHILDKRAUT, J. J. Amphetamine withdrawal: affective state, sleep patterns and MHPG excretion. American Journal of Psychiatry, Arlington, v. 29, p. 263-269, 1972.

WHITCOMB, W. JR. Feeding bees for comb production. Bee Culture, Florida, v. 74, p. 198202, 1946.

WILSON, E. O. The insect societies. Cambridge, MA: Belknap Press of Harvard University Press, 1971. 548p.

WINSTON, M. L.; KATZ, S. J. Longevity of cross-fostered honey bee workers (Apis mellifera) of European and Africanized races. Canadian Journal of Genetics, Canada, v. 59, p. 1571-1575, 1981.

WINSTON, M. L., TAYLOR, O. R.; Otis, G. W. Some differences between temperate European and tropical African and South American honey bees. Bee World, Cardiff, v. 64, p. 12-21, 1983.

WINSTON, M. L. The impact of a tropical evolved honey bee in temperate climates of North America. In: NEEDHAM, G. R.; PAGE, R. E.; BACKER, M. D.; BOWMAN, C. E. (eds.), Africanized honeybees and mites. Chilchester, England: Ellis Horwood, 1988, p. 136-140.

WITT, P. N. Die wirking Von substanzen auf den Netzbau der sipnne als biologischer test. Berlin: Springer-Verlag, 1956. 79 p.

WOLINSKY, I.; HICKSON-JUNIOR, J. F. Nutrição no exercício e no esporte. São Paulo: Ed. Roca, 1996. p. 40-53. 